$\mathrm{DOE} / \mathrm{BP} / 01830--8$

DE91 000198

\title{
A FISHERIES EVALUATION OF THE WESTSIDE DITCH AND WAPATO \\ CANAL FISH SCREENING FACILITIES \\ SPRING 1989
}

Annual Report

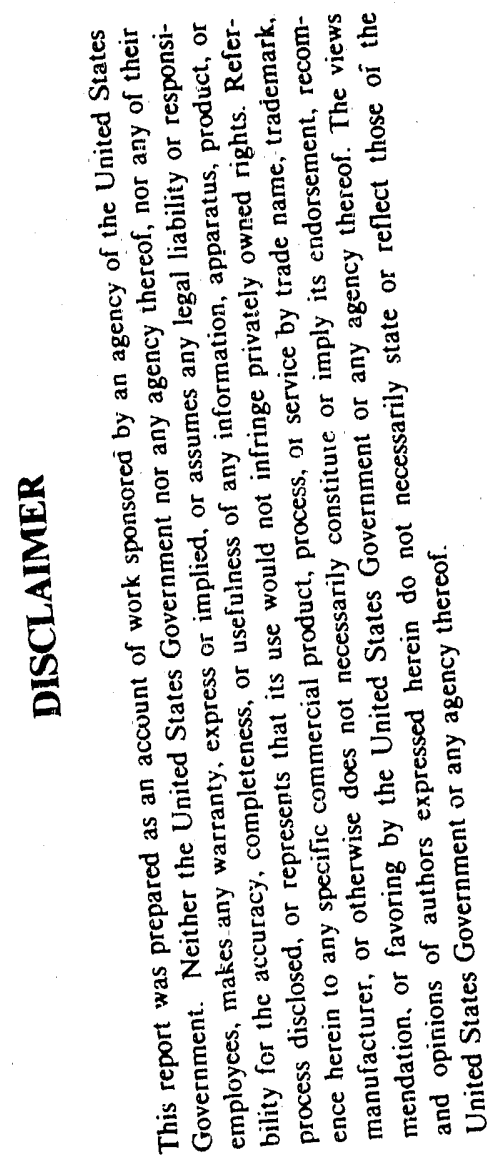

\author{
BY \\ Duane A. Neitzel \\ C. Scott Abernethy \\ E. William Lusty \\ Pacific Northwest Laboratory \\ Prepared For \\ Thomas Clune, Project Manager \\ U.S. Department of Energy \\ Bonneville Power Administration \\ 103 South 3rd Street \\ Yakima, Washington 98901 \\ Project No. 85-62
}

Contract No. DE-AC06-76RLO 1830

June 1990 


\section{PREFACE}

The Bonneville Power Administration, the United States Bureau of Reclamation, and the Washington State Department of Ecology are funding the construction and evaluation of fish passage and protection facilities at irrigation and hydroelectric diversions in the Yakima River Basin. Washington State. This construction implements Sections 903 (d) and 803 (b) of the Northwest Power Planning Council's 1984 and 1987 Columbia River Basin Fish and Wildlife Programs. 1 The programs provide offsite enhancement to compensate for fish and wildlife losses caused by hydroelectric development throughout the Columbia River Basin. and they address natural propagation of salmon to help mitigate the impact of irrigation in the Yakima River Basin.

The Westside Ditch and Wapato Screens are two of the juvenile screening facilities. This report evaluates the effectiveness of the screens facilities for intercepting and returning juvenile salmonids unharmed to the Yakima River from which they were diverted. Studies were conducted in which fish were released upstream of or witin the screen facilities and captured in the diversion that transfers them back to the river. Results indicated that the screens safeiy diverted fish from the canals to the river.

The study emphasized salmonids. Test fish were steelhead Oncorhynchus mykiss smolts, spring chinook salmon 0 . tshawytscha smolts, and rainbow trout 0 . mykiss fry. Evaluations were conducted during typical spring flows in the diversion.

1 Northwest Power Planning Council (NPPC). 1984. ColumbickBiver Basin Eish and Wildlife Program. Northwest Power Planning Council. Portland, Oregon.

Northwest Power Planning Council (NPPC). 1987. Celumbia River Basin Fish and Wildlife Program. Northwest Power P? anning Council. Portland. Oregon. 


\section{ACKNOWLEDGMENIS}

The involvement and cooperation of many people during these studies were greatly appreciated. Thomas J. Clune, Bonneville Power Administration was the Project Manager. Chuck Keller and Ed Spegler. Bureau of Reclamation. and their operations and maintenance staffs provided critical support and assistance during site preparation and data collection. Jack Whitehurst. Westside Irrigation Company, helped with the flow adjustments and maintenance we needed at Westside. Jim Cummins and Jim Lee. Washington Department of Wildlife, and Bill James. Washington Department of Fisheries helped with the procurement of test fish. Jeanne Simpson and Sally Wampler helped with the statistical analysis. Bil? Hanf. Dennis Dauble, and Pete Test helped conduct the field tests. The manuscrint was reviewed by Andy Plymale and Dennis Dauble. 
We evaluated the effectiveness of new fish screening facilities in the Westside Ditch and Wapato Canal in south-central. Washington state. The screen integrity tests indicated that test fish released in front of the screens could enter the canal behind the screens. At Westside Ditch. between $6 \%$ and $25 \%$ of the zero-age fry passed through the rotary drum screens. The $6 \%$ estimate is based on tests with rainbow trout Oncorhynchus mykiss fry. The $25 \%$ estimate is based on monitoring chinook salmon 0 . tshawytscha fry that were diverted from the river into the irrigation ditch.

At Westside Ditch, we estimated that $1.8 \%$ of steelhead 0 . mykiss smolts and $0.3 \%$ of chinook salmon smolts released during tests were descaled. The time required for $50 \%$ of the test fish to exit from the Westside Ditch screen forebay was 3 to $8 \mathrm{~h}$ for chinook salmon smolts and up to $28 \mathrm{~h}$ for steelhead smolts.

Methods used in 1988 were first used at Sunnyside in 1985 and were used in subsequent years at Richland. Toppenish/Satus. Wapato, and Toppenish Creek. The methods and 1985 through 1987 results have been reviewed by the Washington State Department of Fisheries, U.S. Fish and Wild ife Service, National Marine Fisheries Service, Northwest Power Planning Council, and the Yakima Indian Nation. 


\section{CONTENTS}

PREFACE $\ldots \ldots \ldots \ldots \ldots \ldots \ldots \ldots \ldots \ldots \ldots \ldots \ldots \ldots \ldots \ldots \ldots \ldots \ldots \ldots \ldots \ldots \ldots$

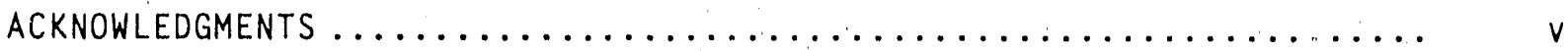

ABSTRACT $\ldots \ldots \ldots \ldots \ldots \ldots \ldots \ldots \ldots \ldots \ldots \ldots \ldots \ldots \ldots \ldots \ldots \ldots \ldots \ldots \ldots \ldots \ldots \ldots \ldots$

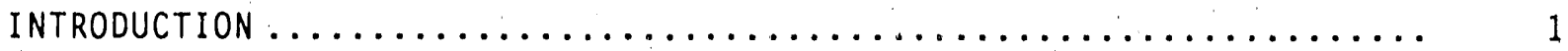

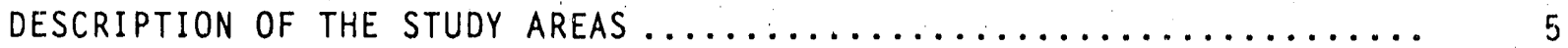

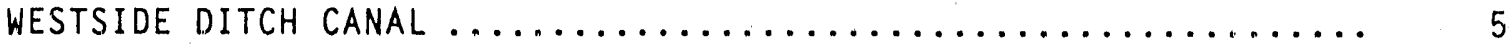

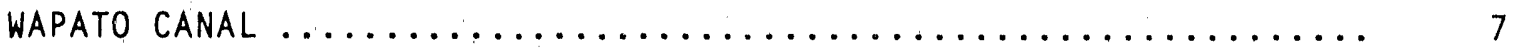

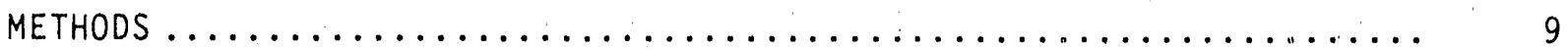

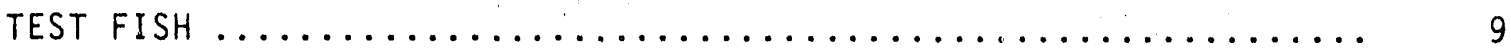

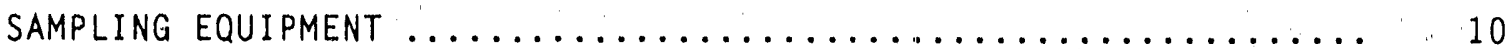

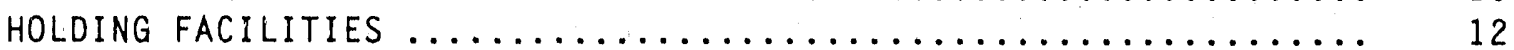

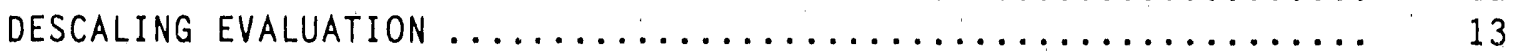

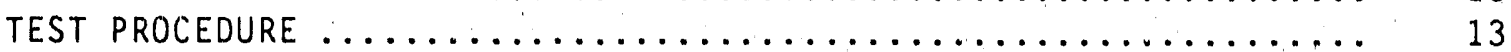

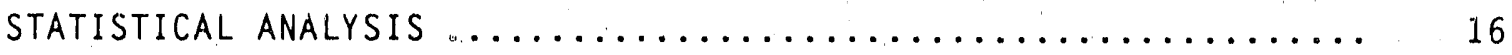

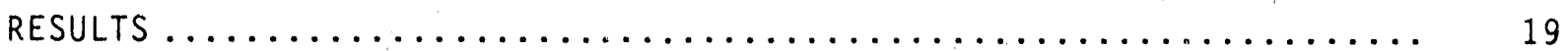

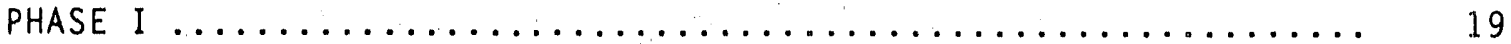

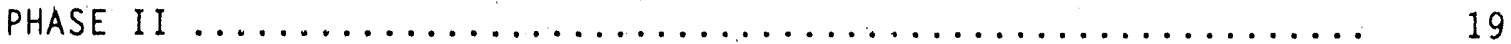

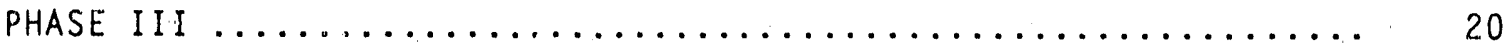

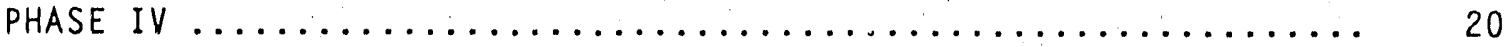

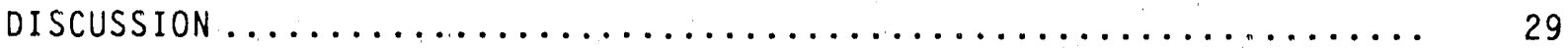

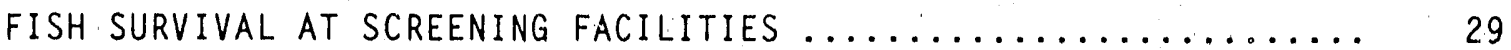

POTENTIAL FOR PREDATION AT SCREENING FACILITIES ............. 29

POTENTIAL FOR FISH DELAY AT SCREENING FACILITIES ............. 30

FISH PASSAGE THROUGH OR OVER ROTARY DRUM SCREENS $\ldots \ldots \ldots \ldots \ldots \ldots . \quad 30$

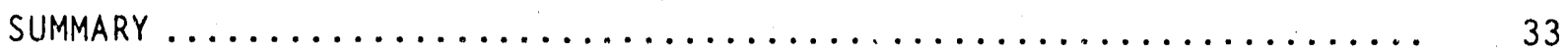

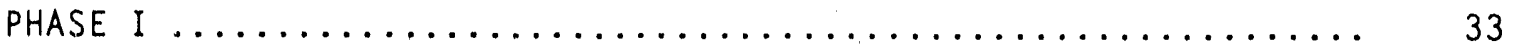

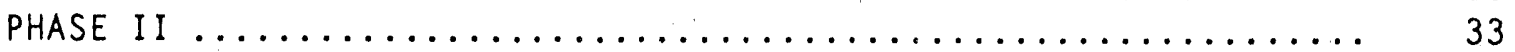

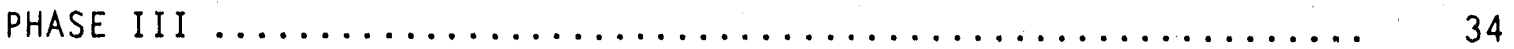

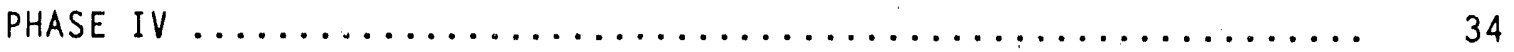

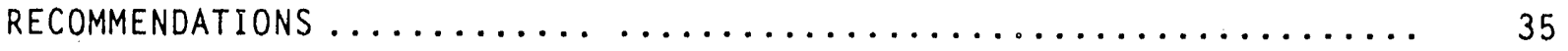

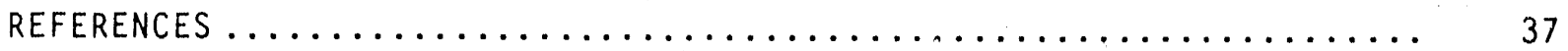

APPENDIX A - WORK PLAN............................ 


\section{EIGURES}

1. Yakima River Basin. Including Locations of the Westside Ditch and Wapato Canal Fish Screening Facilities and Other Fish

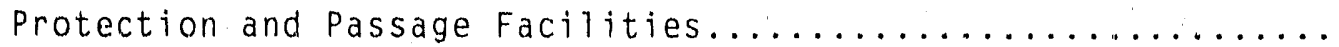

2. Yakima River Basin Showing Location of the Wapato Canal Fish Screening Facility in the Westside Ditch Canal Fish Screening

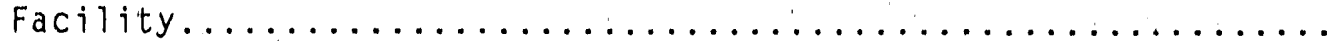

3. Flow Control Structure and Fish Bypass System in the Westside Ditch Canal Fish Screening Facility......................

4. Flow Control Structure and Fish Bypass System in the Wapato

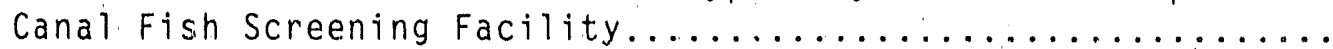

5. Inclined Plane Used at the Westside Ditch Canal Fish Screening

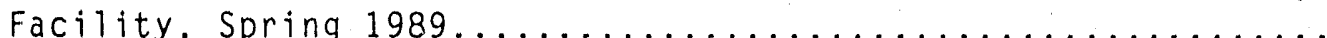

6. Fyke Net Used in Pipe Tests at the Wapato Screens. Spring 1989.

7. Fyke Nets Used in Integrity Tests at the Westside Ditch Screens.

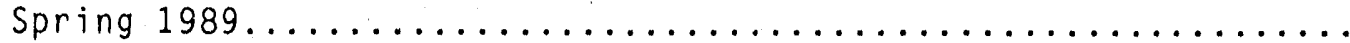

8. Movement of Steelhead Oncorhynchus mykiss Smolts Based on the Capture of Test Fish at the Westside Ditch Canal Fish

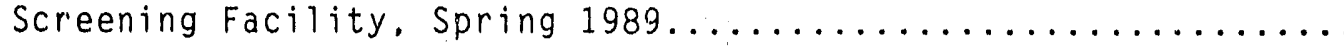

9. Movement of Spring Chinook Salmon Oncorhynchus tshawytscha Smolts Based on the Capture of Test Fish at the Westside Ditch

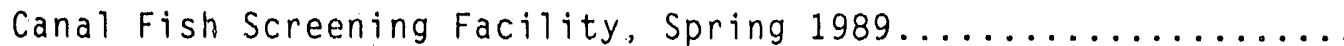

10. Movement of Rainbow Trout Oncorhynchus mykiss Fry Based on the Capture of Test Fish at the Westside Ditch Canal Fish Screening Facility, Spring 1989. 


\section{IABLES}

1. Descaling and Mortality Data from Release and Capture Tests with Steelhead Oncorhynchus mykiss and Spring Chinook Salmon 0 . tshawytscha Smolts at the Westside Ditch Fish

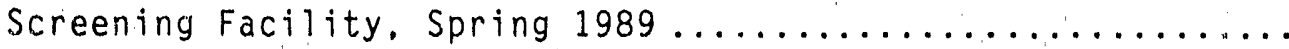

2. Estimated Time to Capture $50 \%$ of Steelhead Oncorhynchus mykiss and Spring Chinook Salmon 0 . tshawytscha Smolts

Released in Descaling Tests at Westside Ditch Fish Screening

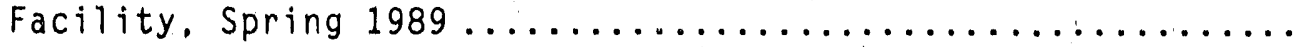

3. Percentage of Spring Chinook Salmon Oncorhynchus tshawytscha Smolts Descaled in Pipe Tests at the Wapato Canal Fish

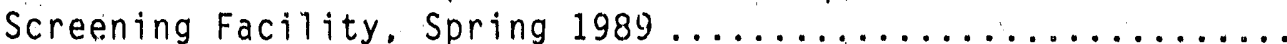

4. Capture Data for Rainbow Trout Oncorhynchus mykiss Fry Released During Screen Integrity Tests at the Westside Ditch Fish

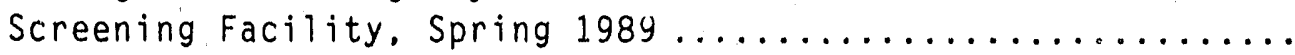

5. Capture Data for Chinook Salmon "11:or" "hus tshawytscha Fry Caught During Screen Integrity Tests at ihe Westside Ditch

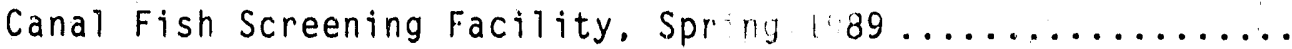

6. Capture Efficiency of the Inclined Plane and Fyke Nets Used During Screen Integrity Tests at the Westside Ditch Canal Fish Screening Facility. Spring $1989 \ldots \ldots \ldots \ldots \ldots \ldots \ldots \ldots$

B.1 Percentage of Coho Salmon Oncorhynchus kisutch Smolts Descaled or Killed During Tests of the Inclined Plane at Sunnyside Canal Fish Screening Facility, Spring $1985 \ldots . . . . . . . . . . .$.

B.2 Percentage of Steelhead Oncorhynchus mykiss and Chinook Salmon 0 . tshawytscha Smolts Descaled or Killed During Tests of the Fyke Net at Sunnyside Canal Fish Screening Facility. Spring 1985

B.3 Percentage of Steelhead Oncorhynchus mykiss Smolts Descaled Before Being Used in Tests at Sunnyside Canal Fish Screening Facility, Spring 1985

B.4 Percentage of Chinook Salmon Oncorhyrichus tshawytscha Smolts Descaled Before Being Used in Tests at Sunnyside Canal Fish

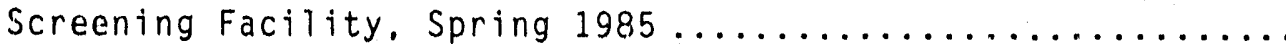

B.5 Percentage of Stetlhead Oncorhynchus mykiss Descaled Smolts or Killed in Each Test at Sunnyside Canal Fish Screening Facility, Spring 1985 
B.6 Percentage of Chinook Salmon Oncorhynchus tshawytscha Smolts Descaled or Killed in Each Test at Sunnyside Camal Fish

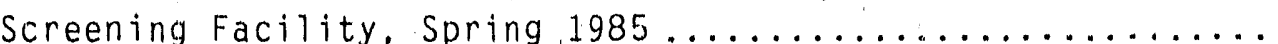

B.7 Scale Loss for Hatchery-Released and Native Fish Captured During Tests at Sunnyside Canal Fish Screening Facility. Spring 1985

B.8 Percentage of Chinook. Salmon Oncorhynchus tshawytscha Smolts Descaled or Killed During Tests of the Inclined Plane at Richlarld Canal Fish Screening Facility, Spring 1986 .........

B.9 Percentage of Chinook Salmon Oncorhynchus tshawytscha Smolts Descaled or Killed During Tests of the Fyke Net at Richland Canal Fish Screening Facility. Spring $1986 \ldots \ldots \ldots \ldots \ldots \ldots$

B.10 Percentage of Steelhead Oncorhynchus mykiss Smolts Descaled Before Being Used in Tests at Richland Canal Fish Screening

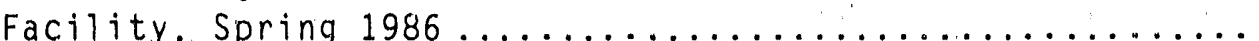

B.11 Percentage of Chinook Salmon Oncorhynchus tshawytscha Smolts Descaled Before Being Used in Tests at Richland Canal Fish Screening Facility, Spring 1986

B.12 Descaling and Mortality Data from Release and Capture Tests with Steelhead Oncorhynchus mykiss Smolts at Richland Canal

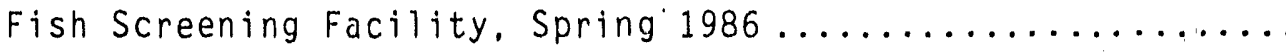

B.13 Descaling and Mortality Data from Release and Capture Tests with Spring Chinook Salmon Oncorhynchus tshawytscha Smolts at Richland Canal Fish Screening Facility. Spring $1986 . . .$. .

B.14 Estimated Time to Catch $50 \%$ and $95 \%$ of Test Fish Captured at Richland Canal Fish Screening Facility, Spring 1986 .......

B.15 Scale Loss for Hatchery-Released and Native Fish Captured During Tests at Richland Canal Fish Screening Facility. Spring 1986

B.16 Percentage of Steelhead Oncorhynchus mykiss Smolts Descaled Before Being Used in Tests at Toppenish/Satus Canal Fish Screening Facility. Spring 1986

B.17. Descaling and Mortality Data from Release and Capture Tests with Steelhead Oncorhynchus mykiss Smolts at Toppenish/Satus Canal Fish Screening Facility. Spring 1986 
B.18 Estimated Time to Catch $50 \%$ and $95 \%$ of Test Fish Captured at Toppenish/Satus Canal Fish Screening Facility.

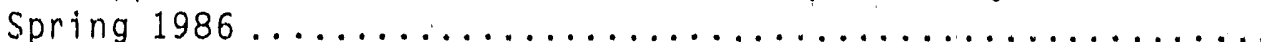

B.19 Scale Loss for Hatchery-Reared and Nature Fish Captured During Tests at Toppenish/Satus Canal Fish. Screening

Facility. Spring 1986

B.20 Peraentage of Spring Cliinook Salmon Oncorhynchus tshawytscha and Steelhead 0 . mykiss Smolts Descaled or Killed During Tests of the Inclined Plane at Wapato Canal Fish

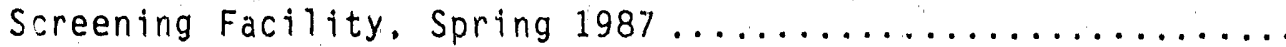

B.21 Percentage of Steelhead Oncorhynchus mykiss Smolts Descaled Before Being Used in Tests at Wapato Canal Fish Screening

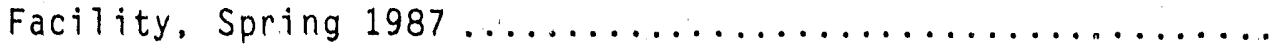

B.22 Percentage of Spring Chinook Salmon Oncorhynchus tshawytscha Smolts Descaled Before Being Used in Tests at Wapato Canal Fish Screening Facility, Spring $1987 \ldots \ldots \ldots \ldots \ldots \ldots \ldots \ldots \ldots$

B.23 Percentage of Steelhead Oncorhynchus mykiss Smolts Descaled or Killed in Each Test at Wapato Canal Fish Screening

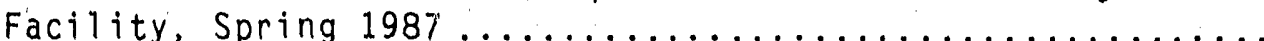

B.24 Percentage of Spring Chinook Salmon Oncorhynchus tshawytscha Smolts Descaled or Killed in Each Test at Wapato Canal Fish

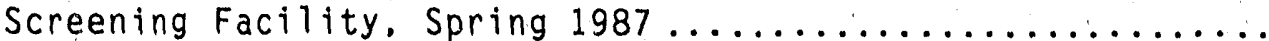

B.25 Scale Loss for Hatchery-Released and Native Salmonids During Tests at Richland Canal Fish Screening Facility.

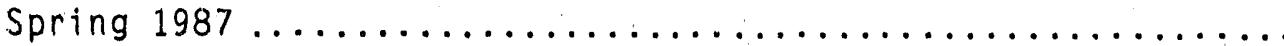

B.26 Scale Loss for Hatchery-Released and Native Salmonids Captured During Tests at the Wapato Canal Fish Screening Facility, Spring 1987

B.27 Percentage of Test Fish Descaled or Killed During Pipe Tests at Wapato Canal. Fish Screening Facility.

B.28 Estimated Time to Capture 50\% and 95\% of the Test Fish Released at Wapato Canal Fish Screening Facility. Spring 1987

B.29 Capture Data for Fall Chinook Salmon Oncorhynchus tshawytscha Fry Released at Richland Canal Fish Screening Facility.

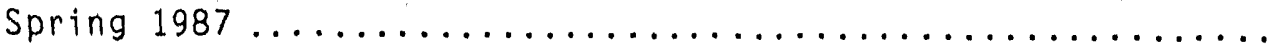


B.30 Capture Efficiencies of the Inclined Plane and Nets and Retention Efficiency of the Fyke Nets Used in Screen Integrity Tests at Wapato Canal Fish Screening Facility.

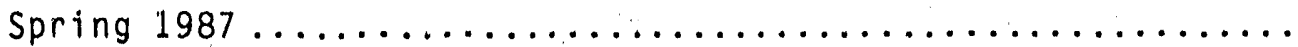

B.31 Capture Data for Fall Chinook Salmon Oncorhynchus tshawytscha Fry Released During Screen Integrity Tasts at Wapato Canal

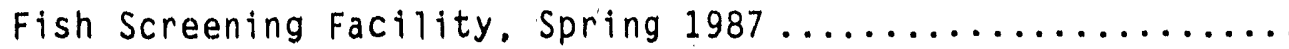

B.32 Estimated Time to Capture $50 \%$ and $95 \%$ of Fall Chinook Salmon Oncorhynchus tshawytscha Fry Released in Screen Integrity Tests at Wapato Canal Fish Screening Facility.

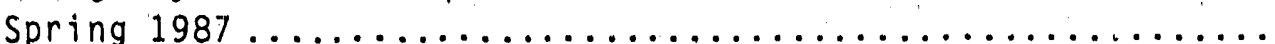

B.33 Percentage of Steelhead Oncorhynchus mykiss Smolts Descaled or Killed in Tests of the Inclined Plane at the Toppenish Creek Canal Fish Screening Facility. Spring $1988 \ldots \ldots \ldots \ldots \ldots$

B.34 Percentage of Steelhead Oncorhynchus mykiss Smolts Descaled Before Being Used in Tests at the Toppenish Creek Canal Fish

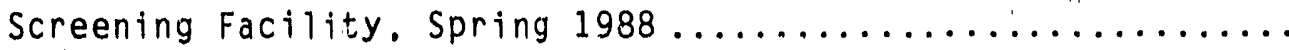

B.35 Descaling and Mortality Data from Release and Capture Tests with Steelhead Oncorhynchus mykiss Smolts at the Toppenish Creek Fish Screening Facility, Spring $1988 \ldots \ldots \ldots \ldots \ldots \ldots$

B.36 Estimated Time to Capture $50 \%$ of Steelhead Oncorhynchus mykiss Smolts Released in Descaling Tests at Toppenish

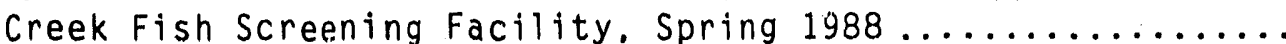

B.37 Estimated Time to Capture $50 \%$ of Rainbow Trout Oncorhynchus mykiss Fry Released in Screen Integrity Tests at Toppenish

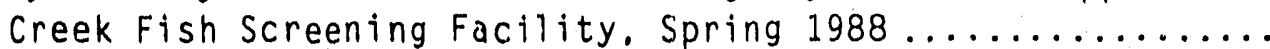

B.38 Percentage of Steelhead Oncorhynchus mykiss Smolts Descaled In Pipe Tests at the Toppenish Creek Fish Screening Facility.

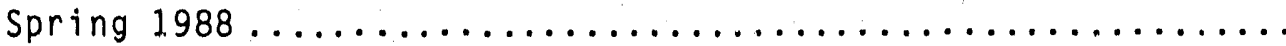

B.39 Capture Data for Rainbow Trout Oncorhynchus mykiss Fry Released During Screen Integrity Tests at the Toppenish Creek Fish Screening Facility, Spring $1988 \ldots \ldots \ldots \ldots \ldots \ldots$

B.40 Capture Efficiency of the Inclined Plane and Fyke Nets Used During Screen Integrity Tests at the Toppenish Creek Fish

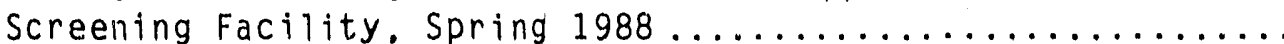


B.41 Estimated Time to Capture 50\% of Fall Chinook Salmon

Oncorhynchus tshawytscha Fry Released in Screen Integrity

Tests at the Wapato Fish Screening Facility. Spring 1988....

B.42 Capture Data for Spring Chinook Salmon Oncorhynchus tshawytscha

Fry Released During Screen Integrity Tests at the Wapato Canal

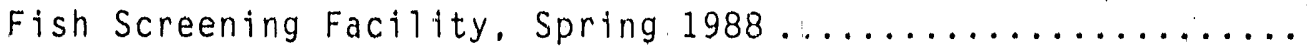

B.43 Capture Efficiency of the Inclined Plane and Nets and

Retention Efficiency for Fyke Nets Used During Screen

Integrity Tests at the Wapato Canal Fish Screening

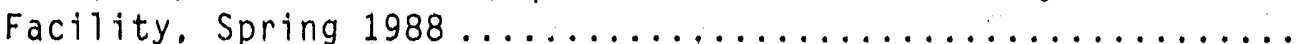

B.44 Capture Data from Fyke Nets Behind Selected Screens at the Wapato Canal Fish Screening Facility After the Release of Yakima Indian Nation Fall Chinook Salmon Oncorhynchus tshawytscha from Net Pens in the Wapato Screen Forebay.

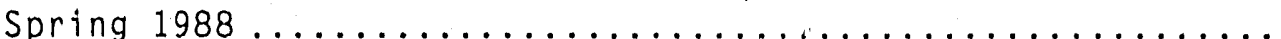

B.45 Estimated Tine to Capture $50 \%$ of Fall Chinook Salmon Oncorhynchus tshawytscha Fry Released in Screen Integrity Tests at the Sunnyside Fish Screening Facility. Spring $1988 \ldots$

B.46 Capture Data for Fall Chinook Salmon Oncorhynchus tshawytscha Fry Reléased During Screen Integrity Tests at the Sunnyside Fish Screening Facility. Spring $1988 \ldots \ldots \ldots \ldots \ldots \ldots \ldots \ldots \ldots$

B.47 Capture Efficiency of the Inclined Plane and Fyke Nets Used During Screen Integrity Tests at the Sunnyside Canal Fish Screening Facility. Spring $1988 \ldots \ldots \ldots \ldots \ldots \ldots \ldots \ldots \ldots$

B.48 Capture Data From Fyke Nets Behind Selected Screens at the Sunnyside Canal Fish Screening Facility After the Release of Yakima Indian Nation Fall Chinook Salmon Oncorhynchus tshawytscha Fingerlings from the Wapato Screens Forebay.

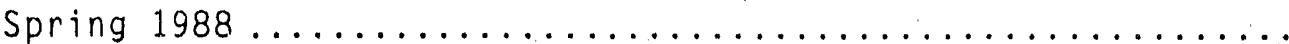

B.49 Descaling and Mortality Data from Release and Capture Tests with Steelhead Oncorhynchus mykiss and Spring Chinook Salmon 0 . tshawytscha Smolts at the Westside Ditch Fish

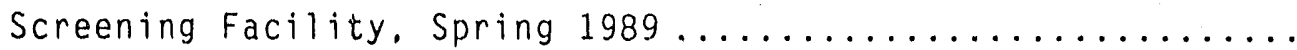

B.50 Estimated Time to Capture $50 \%$ of Steelhead Oncorhynchus mykiss and Spring Chinook Salmon 0. tshawytscha Smolts Released in Descaling Tests at Westside Ditch Fish Screening

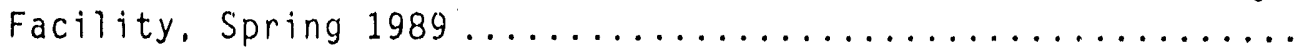


B.51 Percentage of Spring Chinook Salmon Oncorhynchus tshawytscha Smolts Descaled in Pipe Tests at the Wapato Canal Fish

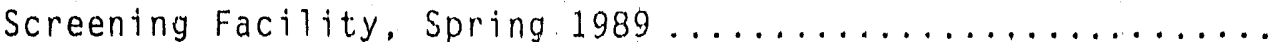

B.52 Capture Data for Rainbow Trout Oncorhynchus mykiss Fry Released During Screen Integrity Tests at the Westside Ditch Fish

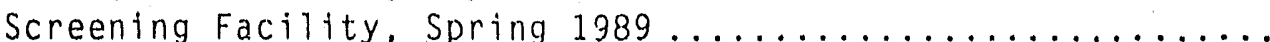

B.53 Capture Data for Chinook Salmon Oncorhynchus tshawytscha Fry Caught During Screen Irtegrity Tests at the Westside Ditch Canal Fish Screening Facility, Spring $1989 \ldots \ldots \ldots \ldots \ldots \ldots \ldots$

B.54 Capture Efficiency of the Inclined Plane and Fyke Nets Used During Screen Integrity Tests at the Westside Ditch Canal

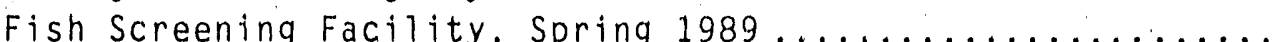




\section{INTRODUCTION}

The Yakima River Basin historically has supported significant runs of salmonids. During the late 1800 s, between 500,000 and 600,000 adult salmon and steelhead Oncorhynchus spp. returned to the Yakima River and its tributaries (Bureau of Reclamation 1984). Runs of salmon included several races: spring, summer, and fall chinook salmon 0 . tshawytscha, coho salmon 0 . kisutch, sockeye salmon 0 . nerka, and steelhead 0 . mykiss.

Some of the runs now are extinct or near extinction. Spawning escapement averaged about 2000 salmonids in the early 1980s (Bureau of Reclamation 1984). There is no sockeye run in the Yakima River Basin today, and only 37 coho salmon passed the Prosser Diversion Dam in 1983 (Hollowed 1984). Recent improvements in efforts to manage and enhance salmonid runs in the Yakima River increased the total spawning escapement to between 5.000 and 10.000 adults in the mid-1980s (Fast et al. 1986).

Reduced numbers of salmonids returning to the Yakima River Basin result from many factors. Spawning and rearing habitat is less because reduced in-stream flow downstream of irrigation diversion dams. Ineffective fish passage facilities for adults and juveniles at diversion dams cause high mortality during migration. Additionally, many Yakima River fish are killed while passing hydroelectric dams on the inainstem Columbia River.

The Pacific Northwest Electric Power Planning and Conservation Act (Public Law 96-501) was passed to enable preparation and implementation of a regional Conservation and Electric Power Plan. The Northwest Power Plannirg Council administers the Plan, and is charged with developing a prograin to protect and enhance fish and wildlife populations and to mitigate adverse effects from development, operation, and management of hydroelectric facilities.

The "akima River Basin was selected as one site for enhancement of salmon and iteelhead runs. Under the Plan, the Bonneville Power Administration (BPA) and the Bureau of Reclamation (BR) are funding the construction of fish passage and protection facilities at irrigation and hydroelectric diversions in the Yakima River Basin (Figure 1). BPA is also providing funds to the Yakima Indian Nation to increase production of spring chinook salmon in the Yakima River Basin.

The Westside Ditch and Wapato Canal Fish Screening Facilities (Westside and Wapato Screens) are part of the passage and protection facilities being constructed in the Yakima River Basin by BPA and BR. Construction of the Wapato and Westside Screens was completed in 1985 and 1989, respectively. BPA asked the Pacific Northwest Laboratory (PNL) to evaluate the effectiveness of these diversion facilities in returning to the river fish that had entered the canals. 
This report covers work by PNL fisheries staff at the Westside and Wapato Screens in 1989. It describes each screen facility, methods used to evaluate the effectiveness of the screens, and test results. Our findings are discussed and compared with results from previous tests at the Sunnyside Screens (Neitzel et al. 1985), at the Richland and Toppenish/Satus Screens (Neitzel et al. 1986), at the Richland and Wapato Screens (Neitzel et al. 1988), and at the Toppenish Creek. Wapato, and Sunnyside Screens (Neitzel et al. 1990). The report includes two appendices. Appendix $A$ is a description of the work plan prepared to guide the evaluations and to associate specific objectives with the methods used during the evaluations. Appendix $B$ lists tables of the data collected at the Sunnyside Screens in 1985, the Richland and Toppenish/Satus Screeris in 1986. the Richland and Wapato Screens in 1987, the Wapato. Sunnyside and Toppenish Creek screens in 1988, and the Westside and Wapato Screens in 1989. 


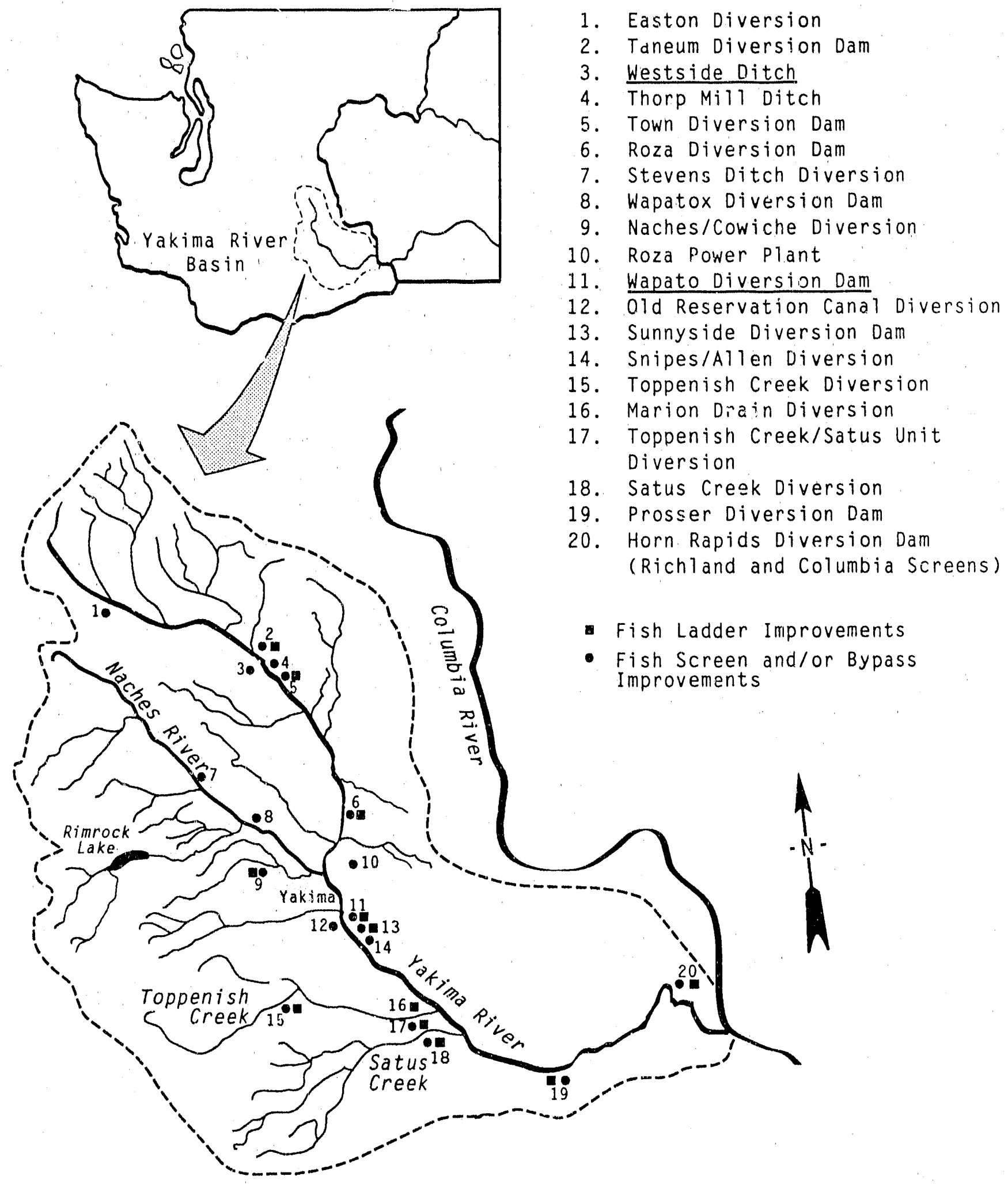

EIGURE 1. Yakima River Basin. Including Locations of the Westside Ditch and Wapato Canal Fish Screening Facilities and Other Fish Protection and Passage Facilities 
During 1989, studies were conducted at the Wapato arid Westside Ditch screening facilities. Tests were conducted on the fish return pipe at the Wapato Screens. The study area for the Westside Ditch Screens included the canal upstream of the screens, the screens forebay, and the canal behind the screens. Specific conditions tested during the evaluations are reported in the Results and Discussion sections.

\section{WESTSIDE DITCH CANAL}

The Westside Ditch Diversion is located on the Yakima River at river $\mathrm{km}$ 267.4 [river mile (RM) 166.2], near Thorpe. Washington. Water is diverted from the Yakima River into the Westside Ditch Canal. The carrying capacity of the canal is about $2.8 \mathrm{~m}^{3} / \mathrm{s}$ [100 cubic feet per second (cfs)]. Canal flow varies from 0.6 to $2.8 \mathrm{~m} 3 / \mathrm{s}$ ( 20 to $100 \mathrm{cfs}$ ) and is regulated at the canal head gates located about $0.5 \mathrm{~km}$ upstream of the Westside Ditch screens. The screening facility (Figures 2 and 3 ) diverts fish that have entered the canal and directs them back to the Yakima River. Trash racks

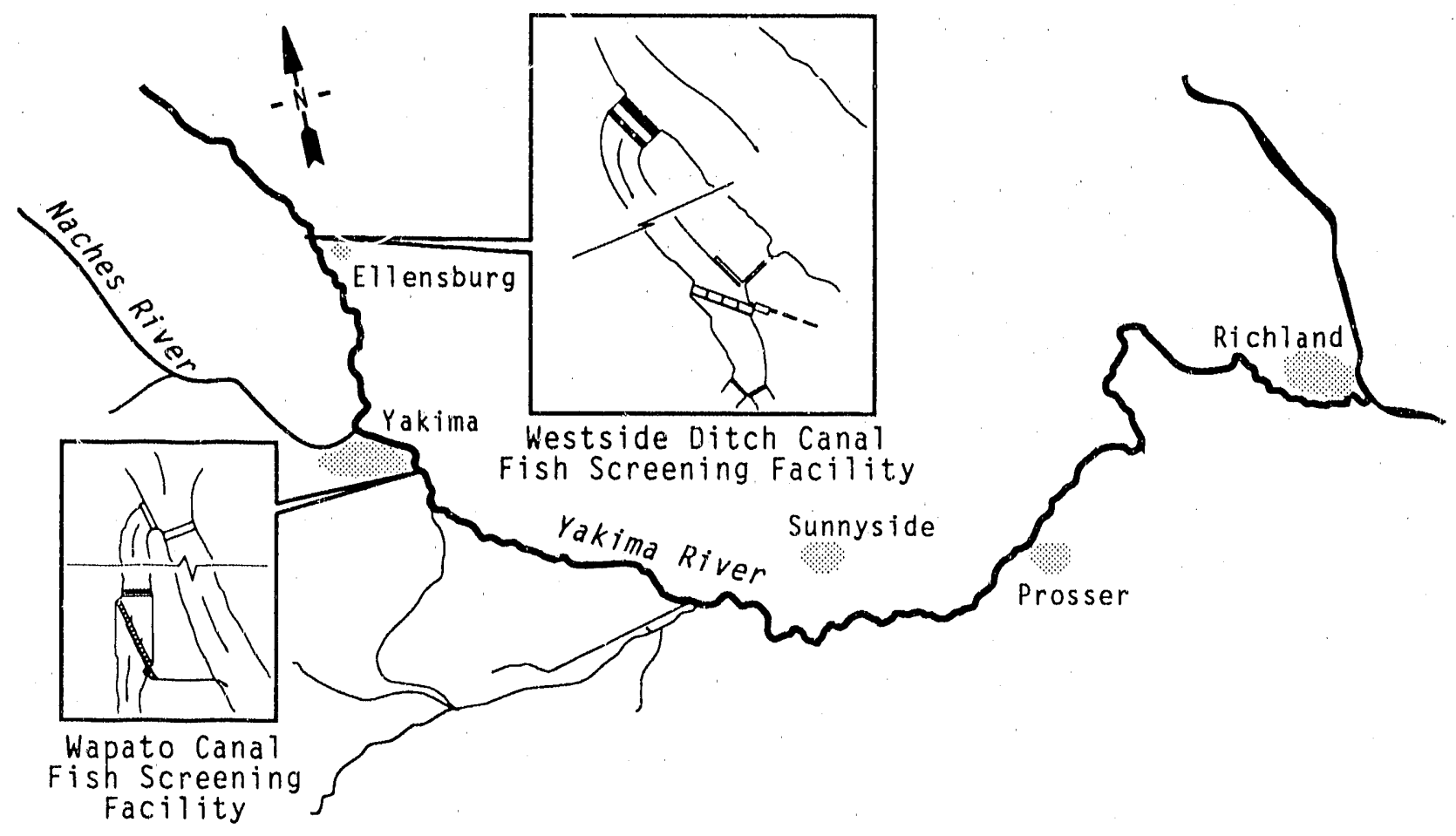

EIGURE 2. Yakima River Basin Showing Location of the Wapato Canal Fish Screening Facility anc the Westside Ditch Canal Fish Screening Facility 


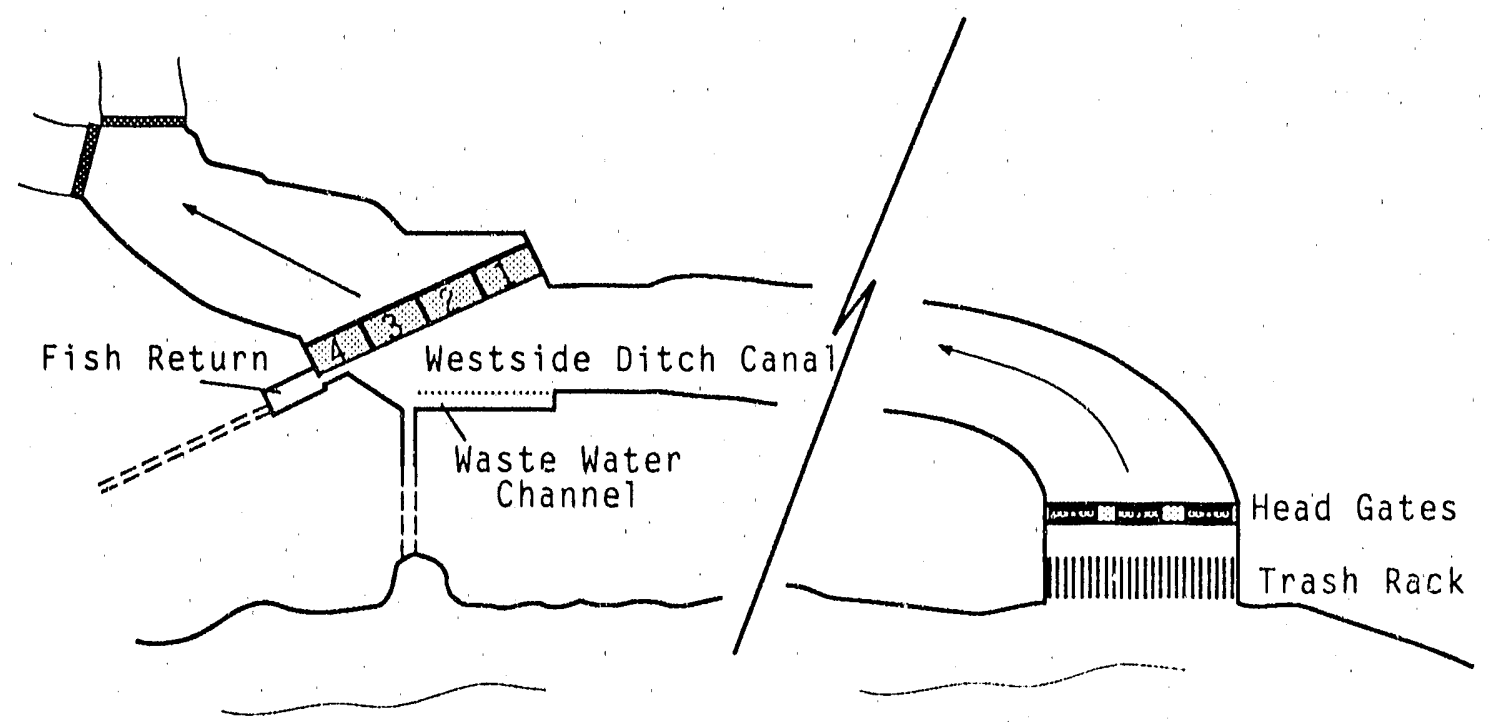

Yakima River

FIGURE 3. Flow Control Structure and Fish Bypass system in the Westside Ditch Canal Fish Screening Facility

located in front of the head gates "filter" out large debris that could damage the screens or interfere with flow control through the screen facility.

The screening facility (Figure 3 ) houses four rotary drum screens with axes parallel to the length of the structure. Each screen is about $3.7 \mathrm{~m}$ (12 $\mathrm{ft})$ long and $1.8 \mathrm{~m}(6 \mathrm{ft})$ in diaineter. Screen mesh openings are $3.2 \mathrm{~mm}$ $(1 / 8$ in.). Water depth at the screens is maintained at about $1.6 \mathrm{~m}$ ( $5 \mathrm{ft})$. The fish bypass is located in the flow control structure at the downstream end of the screening facility. Water and fish diverted past the front of the screens pass through the fish bypass slot and out the fish return pipe. Flow through the fish return is $0.6 \mathrm{~m} 3 / \mathrm{s}$ ( $20 \mathrm{cfs}$ ). A waste water channel is installed along the forebay wall opposite the drum screens to prevent flooding and canal bank erosion. No water flows out the waste water channel at normal canal forebay level.

The rotary screens are installed at an angle of $26^{\circ}$ to canal flow. This orientation is designed to provide a sweeping-velocity-to-approach-velocity ratio equal to or exceeding 2:1 (Easterbrooks 1984). The maximum allowable approach velocity is $0.15 \mathrm{~m} / \mathrm{s}$ ( $0.5 \mathrm{fps}$ ). Screen orientation and flow velocity differential help direct fish to the fish return pipe and back to the river. 


\section{WAPATO CANAL}

The Wapato Diversion (Figure 2) is located at river km 172 (RM 106.7) on the Yakima River. The diversion directs water from the Yakima River into the Wapato Canal. Canal operation begins in early March and continues through the irrigation season, usually until mid-October. Canal capacity is about $57 \mathrm{~m}^{3} / \mathrm{s}(2000 \mathrm{cfs})$.

The Wapato Canal Fish Screening Facility (Wapato Screens) is located about $1 \mathrm{~km}$ downstream of the head gates of the Wapato Canal. The screening facility (Figure 4) diverts fish entering the canal and directs them back to the Yakima River.

The trash racks from the old screening facility. immediately upstream of the new Wapato Screens, are used to "filter" out debris entering the canal. The screening facility houses 15 rotary drum screens (Figure 4 ) with axes parallel to the length of the structure. Each screen is about $7.3 \mathrm{~m}$ $(24 \mathrm{ft})$ long and $4.6 \mathrm{~m}(15 \mathrm{ft})$ in diameter. Water depth at the screens varies with canal flow; however, the depth across the face of the screens at full canal level is normally about $3.7 \mathrm{~m}(12 \mathrm{ft})$.

The flow control structure and the separation chamber (Figure 4 ) are located at the downstream end of the screen facility. Two fish bypass pipes and the terminal bypass, each with a flow of about $1.4 \mathrm{~m}^{3} / \mathrm{s}$ ( $50 \mathrm{cfs}$ ). feed into the separation chamber. During normal operation, about $4.2 \mathrm{~m} 3 / \mathrm{s}$ ( $150 \mathrm{cfs}$ ) of water enter the separation chamber. About $0.9 \mathrm{~m} 3 / \mathrm{s}$ ( $30 \mathrm{cfs}$ ) of water and all fish that are diverted in front of the screens pass through the flow control structure and out the fish return pipe. Two bypass water return pumps, each with a pumping capacity of $1.4 \mathrm{~m} 3 / \mathrm{s}$ (50 cfs), are located behind traveling screens near the terminus of the separation chamber. The traveling screens are equipped with screen washers to prevent fish and debris from being entrained in the pumpback system.

The pumpback system is not used during normal operation. Adequate flows are maintained in the fish bypass by discharging $3.4 \mathrm{~m} 3 / \mathrm{s}$ (120 cfs) of water back to the Yakima River over adjustable weirs in the pump basin. When the pumps are operating. flow over the weirs is reduced. Thus, bypass flows are achieved by adjusting weirs in each fish bypass (Gates 1. 2. and 3 ). the fish return (Gate 4 ), and the two weirs behind the pump intakes (Gates 5 and 6 ). 


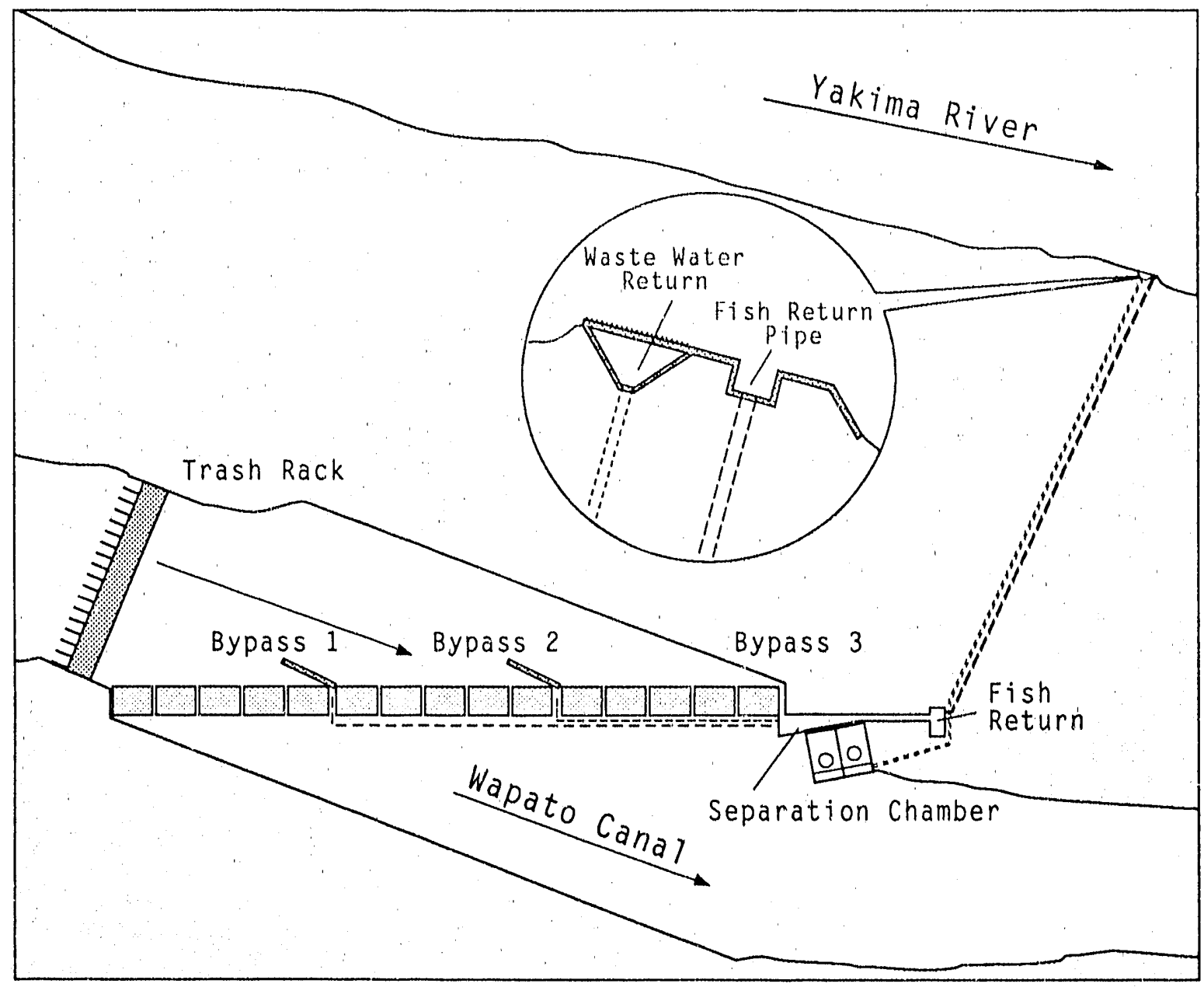

FIGURE 4. Flow Control Structure and Fish Bypass System in the Wapato Canal Fish Screening Facility 


\section{METHODS}

Two types of tests were conducted in 1989: descaling (Phase II) tests and screen integrity (Phase IV) tests. In Phase IIb tests at the Wapato Screens. fish were released at the head of the fish return pipe and captured at the terminus of the pipe. In Phase IIa tests at the Westside Ditch. fish were released in the canal upstream of the screening facility and captured as they entered the fish return. Some test fish were held for post-test observation. Native salmonids entering the Westside Ditch Canal were monitored during release/capture tests. In Phase IV tests at the Westside Ditch Canal, fish were released both in front of and behind the screens and were captured as they appeared in the primary fish return or in fyke nets mounted behind the drum screens.

\section{TEST FISH}

The species of fish selected for tests were recommended by fisheries biologists from the Washington State Department of Fisheries (WDF). U.S. Fish and Wildlife Service (USFWS), and the Yakima Indian Nation (YIN). The species were selected based on the potential impact of an irrigation diversion on specific salmonid populations likely to encounter each screening facility during the rearing and outmigration period. Therefore. the selection was dependent on the species, race, and size of salmonids occurring in the Yakima River drainage upstream of each diversion.

Spring chinook salmon smolts were used in Phase II tests at the wapato Screens. The pipe tests repeated previous work conducted at the wapato Screens (Neitzel et al.. 1988). Spring chinook salmon, resident rainbow trout, and possibly steelhead utilize the Yakima river upstream of the Westside Ditch diversion. Spring chinook salmon and steelhead smolts were selected for Phase II tests and rainbow trout fry $(<50 \mathrm{~mm})$ were used in Phase IV tests at the Westside Ditch Screens.

\section{Steelhead}

Juvenile steelhead were obtained from the Washington Department of Wildiife (WDW) Yakima Trout Hatchery in Yakima. Washington. The steelhead were progeny of native steelhead captured at the Prosser fish trap on the Yakima River. The fish were transported to PNL in November, 1988, and were reared throughout the winter in a mixture of ambient Columbia River water and well water. Fish were branded and acclimated to temperatures expected at the Westside Ditch Screens at least 1 week before release. The fish weighed about 22 fish/kg (10 fish/lb) when released in out tests. 


\section{Rainbow Irout}

Rainbow trout fry. used in the Westside Ditch Screens integrity tests, were obtained from PNL brood stock spawned in December 1988. Eggs were hatched in vertical flow incubators supplied with $10^{\circ} \mathrm{C}$ well water. Fry were transferred to troughs and reared at $10^{\circ} \mathrm{C}$ unt 11 testing commenced. Ralnbow trout fry used in tests at the Westside Ditch Screens averaged $49 \mathrm{~mm}$ fork length $(F L)$ and were branded at least one week prior to release.

\section{spring Chinook Salmon}

Yearling spring chinook salmon were obtained from the Leavenworth National Hatchery in Leavenworth. Washingtion. The fish were transported to PNL in February 1988, and held in ambient Columbla River water until used in pipe tests at the Wapato Screens. Fish used in Phase IIa tests at the Westside Ditch Screens were branded at least 1 week before release. The fish weighed about $35 \mathrm{fish} / \mathrm{kg}(16 \mathrm{fish} / 1 \mathrm{~b})$ when released.

\section{SAMPLING EOUIPMENT}

Fish were captured within the screening facility, at the terminus of the primary fish return pipe, and in the canal behind the screens, based on the objectives of each test. An inclined plane was custom-built to fit the fish bypass structure at the Westside Ditch Screens. A fyke net was used to collect fish at the terminus of the wapato Screens fish return pipe. and fyke nets were mounted in stoplog slots behind the rotary drum screens to collect fish at the Westside Ditch Screens. Temporary fish-holding facilities were installed at the Westside Ditch Screens to acclimate and hold test fish.

\section{Inclined Plane}

Fish were captured by placing an inclined plane in the fish return between the last rotary drum screen and the head of the fish return pipe. The inclined plane used at the Westside Ditch Screens (Figure 5) was $2.1 \mathrm{~m}$ $(7.0 \mathrm{ft})$ long and $1.0 \mathrm{~m}(3.3 \mathrm{ft})$ wide. The front face of the plane was hinged so that the slope of the plane could be changed to adjust the flow of water reaching the fish live box. Solid walls, tapering from $0.9 \mathrm{~m}$ $(3 \mathrm{ft})$ at the entrance to $0.41 \mathrm{~m}(1.3 \mathrm{ft})$ at the live box, acted as splash guards to reduce fish loss from the plane. A 1 ive box $[0.38 \mathrm{~m}(1.3 \mathrm{ft})$ long by $1.0 \mathrm{~m}(3.3 \mathrm{ft})$ wide, 1001 ( $26 \mathrm{gal})$ volume] was fastened at the end of the inclined plane. The inclined plane had an aluminum frame covered with a perforated aluminum sheet $[0.32-\mathrm{cm}-(1 / 8-i n,-)$ diameter holes. staggered centers, $40 \%$ oper.]. Flow was directed over the plane surface by inserting dam boards in the upstream stoplog slot in the fish bypass slot. The height of the dam boards relative to the water depth determined the water volume through the fish bypass. 


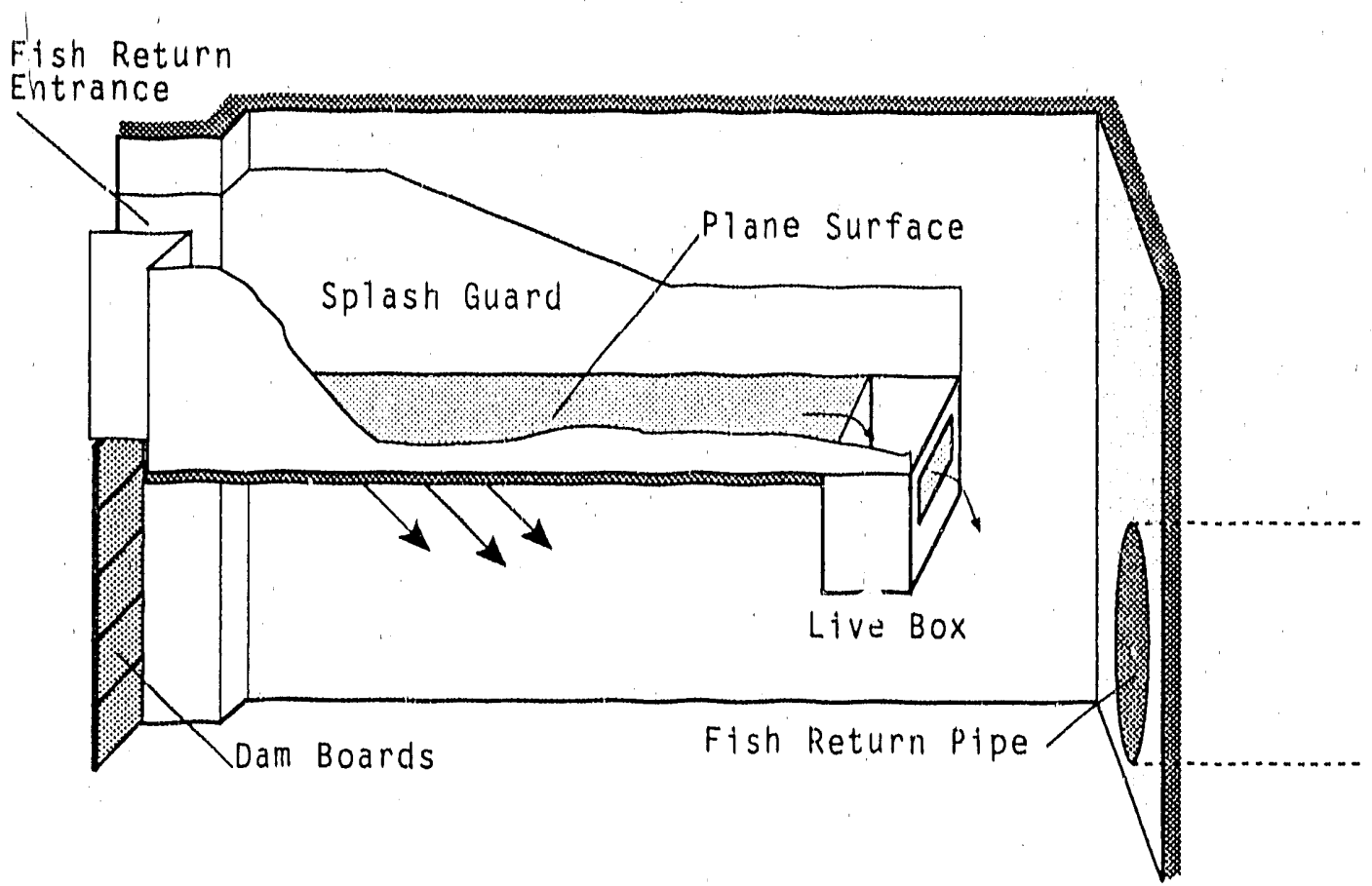

EIGURE 5. Inclined Plane Used at the Westside Ditch Canal Fish Screening Facility, Spring 1989

\section{Fyke Nets}

The fyke net used for pipe tests at the Wapato Screens was attached to a frame that fit into slots in the concrete structure at the terminus of the fish return pipe (Figure 6 ). The frame was equipped with an adjustable solid metal wing that deflected flow from the waste water return and the Yakima River around the flow from the fish return pipe. The deflector was also used as an anchor point to prevent entangiement of the fyke net and to ensure that fish would not be harmed when exiting the fish return pipe. The net mouth was $1.0 \mathrm{~m}(3.3 \mathrm{ft})$ wide and $1.4 \mathrm{~m}(4.5 \mathrm{ft})$ tall and tapered to a $0.5-\mathrm{m}$-square cod end over a length of $4.9 \mathrm{~m}$. A hoop net ( $1 \mathrm{~m}$ diameter. $4 \mathrm{~m}$ long) was fastened to the cod end net to provide additional holding area for fish, extending the length of the net to about $8 \mathrm{~m}$ $(25 \mathrm{ft})$. The portion of the net attached to the deflector wing was constructed of solid vinyl sheeting to protect fish from net abrasion as they exited the fish return pipe.

Fyke nets were used behind each of the four drum screens in integrity tests at the Westside Ditch Screens. The mouths of the nets were $3.7 \mathrm{~m}$ (12 ft) wide and $1.8 \mathrm{~m}$ ( $6 \mathrm{ft}$ ) deep. The tops of the nets were above the water surface, and the bottoms of the nets settled into the mud on the canal floor. The net mouth tapered down to the $0.91 \cdot \mathrm{m}-(3-\mathrm{ft})$ square mouth of the cod net over a length of $4.6 \mathrm{~m}(15 \mathrm{ft})$. The two sides of the net were 


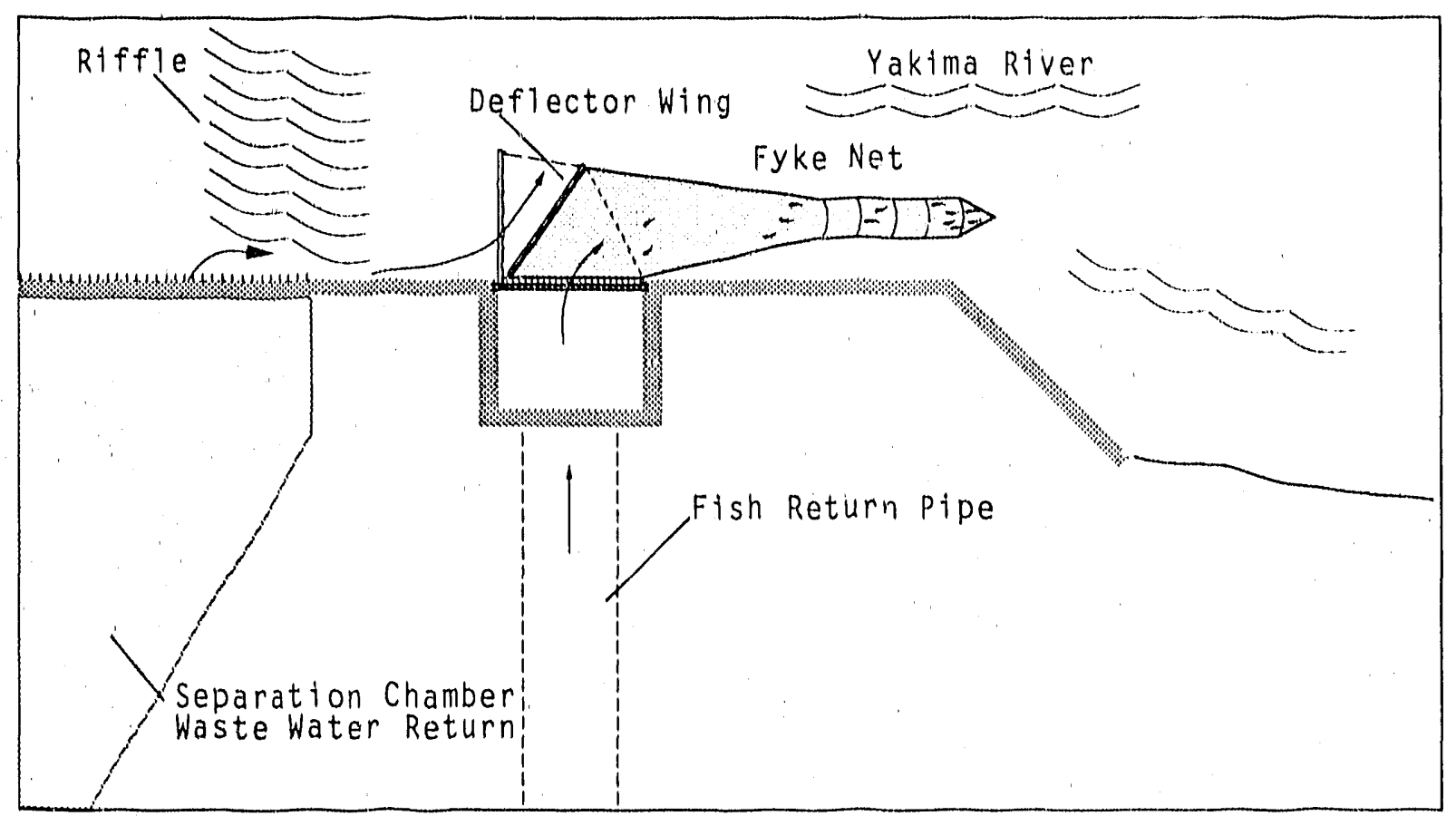

EIGURE 6. Fyke Net Used in Pipe Tests at the Wapato Screens, Spring 1989

of different lengths so that the net would hang parallel to canal flow without billowing on one side (Figure 7$)$. The cod net was $1.8 \mathrm{~m}(6 \mathrm{ft})$ long, resulting in an overall net length of $6.4 \mathrm{~m}(21 \mathrm{ft})$. The end of the cod net was tled shut. The nets were fished continuously during screen integrity tests, except for about $1 \mathrm{~h}$ intervals at the termination of each test, when the nets were iaised from the water for fish retrieval and net cleining.

\section{HOLDING FACILITIES}

Temporary factlities were installed at the Westside Ditch Screens to hold fish during descaling evaluation and to retain some fish for $96 \mathrm{~h}$ after capture. A mobile laboratory containing three fiberglass troughs [ $3 \mathrm{~m}$ ( 10 $\mathrm{ft}$ ) long by $0.6 \mathrm{~m}(1.8 \mathrm{ft})$ wide, $0.3 \mathrm{~m}(0.8 \mathrm{ft})$ deep, and 5401 (140 gal) in volume], and two fiberglass circular tanks $[1.22 \mathrm{~m}$ ( $4 \mathrm{ft}$ ) in diameter by $0.6 \mathrm{~m}(2 \mathrm{ft})$ deep] was moved onto the site. All tanks were supplied with canal water that was pumped from behind the screens. The moblle lab was equipped with fluorescent lighting so that fish captured during both the day and night could be evaluated for descaling under similar light conditions. 


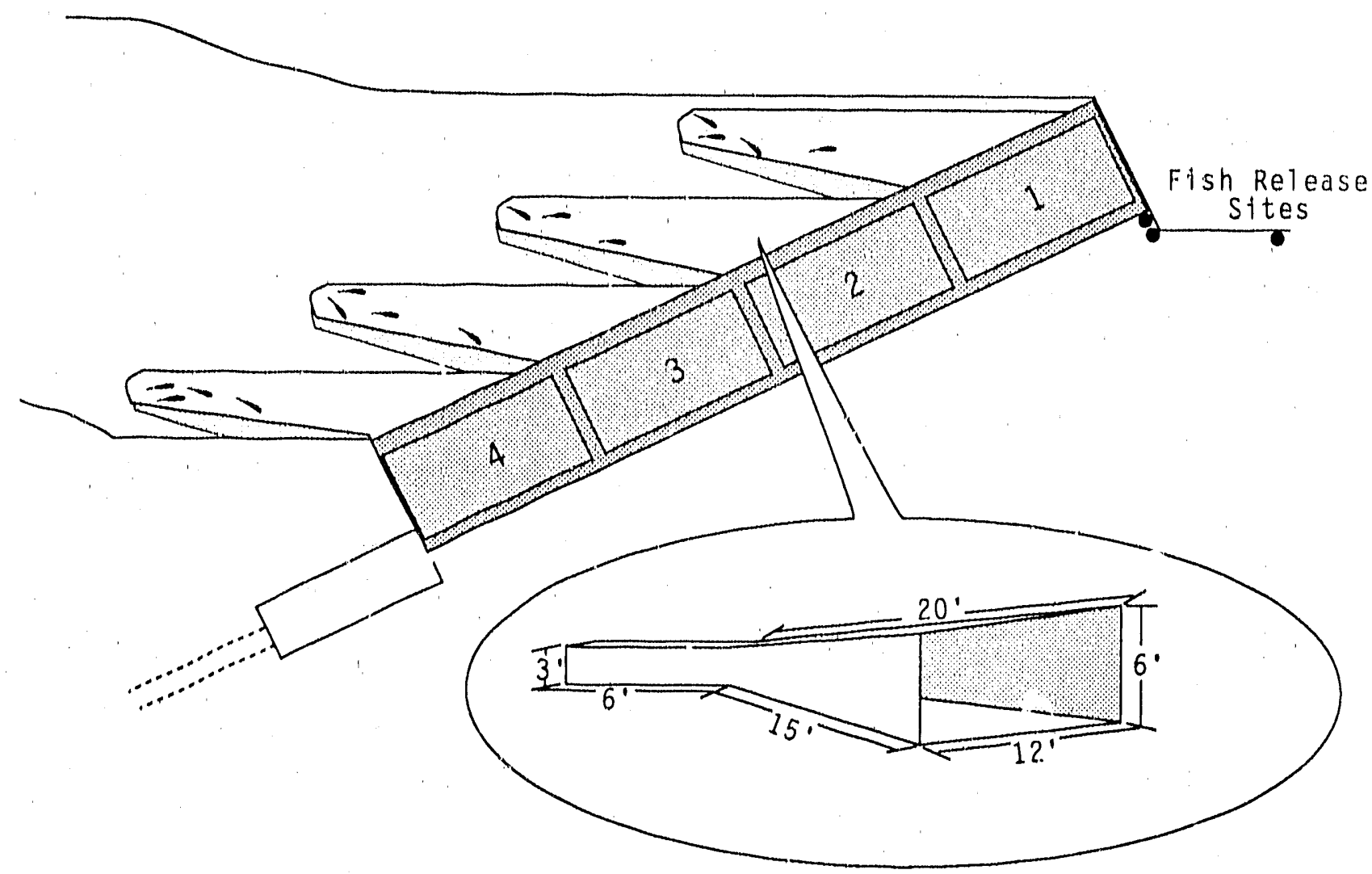

EIGURE 7. Fyke Nets Used in Integrity Tests at the Westside Ditch Screens. Spring 1989

\section{DESCALING EVALUATION}

An evaluation system developed by the U.S. Army Corps of Engineers (Basham et a 1. 198? 1 was used to monitor the condition of fish at both sites. Evaluation criteria included modifications established in 1985 (Neitzel et a1. 1985). Baseline descaling condition was determined by randomly sampling groups of test fish before their release. Descaling was evaluated in each of 10 areas. 5 on each side of the fish. When $40 \%$ or more scale loss was observed in any 2 areas on one side of a fish. the fish was classified as descaled.

\section{IEST PROCEOURE}

Pipe tests at the Wapato Screens were accomplished by releasing spring chinook salmon smolts at the head of the fish return pipe and capturing them in a fyke net mounted on the terminus of the fish return pipe. The tests were conducted during the daytime when movement of native salmonids would not interfere with collection. 
Descaling evaluations at the Westside Ditch Screens were made by introducing branded groups of steelhead and spring chinook salmon smolts into the canal upstream of the screenting facility and capturing the fish when they appeared on the inclined plane in the primary fish return. (Phase IIa. Appendix A). Tests were conducted during the last week in April. Flows were set and maintained near maximum canal flow. Native salmonid populations were monitored during tests at the Westside Ditch Screens (Phase IVa. Appendix A). Screen integrity tests were conducted at the Westside Ditch Screens by releasing branded groups of rainbow trout in front of and behind the rotary screens (Phase IVD. Appendix A). Fish were collected as they appeared either on the inclined plane in the fish return or in fyke nets placed in the canal behind the screens.

\section{Iest Stock Identification}

Test fish were cold branded to identify specific test groups. Steelhead and spring chinook salmon were marked either in the right anterior or the right dorsal. The brands were applied at least 1 week before release. The brands used in our studies, approved by the National Marine Fisheries Service (NMFS), were distinguishable from all other brands used in the Columbia River Basin. Spring chinook salmon used in pipe tests at the Wapato Screens were not marked.

\section{Eish Iranspert and Release}

Test fish were transported at acclimation temperature in an insulated tank [400 1 (125 gal) in volume] supplied with oxygen. Transit times from PNL to the Westside Ditch and Wapato screens were $2.5 \mathrm{~h}$ and $1.3 \mathrm{~h}$. respectively. Loading densities did not exceed $120 \mathrm{~g}$ of $\mathrm{fish} / 1$. Water temperature in the transporter changed less than $1^{\circ} \mathrm{C}$ during transit. Test fish were netted from the transporter and placed in holding tanks at the facility for acclimation before release into the canal for tests at the Westside Ditch Screens. Test fish used in pipe tests at the Wapato Screens were netted from the transport tank into buckets and poured directiy into the head of the fish return pipe. No losses were attributable to transporting stress.

\section{Eish Release Lecations}

Test fish for descaling evaluation at the Westside Ditch Screens were released from the north bank of the canal about $150 \mathrm{~m}$ upstream of the screening facility. Rainbow trout used in Phase IV tests at the Westside Ditch Screens were released just upstream of the first rotary screen near the structure wall (Figure 7) and uniformly across the mouth of the fyke nets positioned on the downstream side of the rotary screens. Fish were also released at the entrance to to the inclined plane to test gear efficiency and effect. In Phase IIb tests at the Wapato Screens, fish were released at the head of the fish return pipe. where the water falls over 
Gate 4 in the terminus of the fish return slot, and in the mouth of the fyke net mounted at the terminus of the fish return pipe.

\section{Release Controls}

The condition of test fish at the time of release (baseline condition) for fish used in Phase IIb tests at the Wapato Screens and in Phase IIa tests at the Westside Ditch Screens was estimated by sampling each group of test fish before release. Baseline condition evaluations were conducted under natural light conditions at the Wapato Screens, and inside the mobile laboratory under artificial light for Phase IIa tests at the Westside Ditch Screens. For Phase IIb tests at the Wapato Screens, 110 spring chinook salmon smolts were evaluated for baseline condition. $105 \mathrm{fish}$ were evaluated to measure descaling caused by collection gear, and 150 were released at the head of the fish return pipe. For Phase II tests at the Westside Ditch Screens, 100 steelhead and 100 spring chinook salmon smolts were sampled for baseline condition, 60 steelhead and 70 spring chinook salmon were evaluated to measure descaling caused by collection gear. and 750. steelhead and 755 spring chinook salmon wer released in front of the screens.

\section{Eish Capture and Evaluation}

Spring chinook salmon used in Phase IIb tests were recovered from the fyke net at the mouth of the Wapato Screens fish return 15 min after their release at the head of the fish return pipe. The cod end of the net was removed srom the water, and the fish were transferred to a bucket and anesthetized in MS-222. The fish were examined to determine scale loss, then placed in another bucket to recover before being released into the Yakima River.

Fish captured during Phase II a tests at the Westside Ditch Screens were netted from the live box of the inclined plane and placed in a holding tank before evaluation. Evaluations were made at half-hour intervals. The fish were anesthetized in MS-222, examined to determine the extent of scale loss, and returned to another holding tank. After fish recovered from the anesthetic, they were released into the fish return pipe. About 100 steelhead and 200 spring chinook salmon smolts were held for $96 \mathrm{~h}$ to monitor delayed mortality.

The purpose of Phase IVb tests was to determine the effectiveness of screening facilities in preventing fish from entering the canal behind the screens, and to monitor the rate at which fish moved through the fish bypass. Thus, fish captured in Phase IVb tests were not evaluated for descaling. Fish were identified by brand group and enumerated as they appeared on the inclined plane in the fish return. The brands identified when and where the fish were released within the screening facility. 
The inclined plane was fished continuously during our tests at the Westside Ditch Screens. Groups of fish for Phase IVb tests ware released in front cif and behind the screens during the morning. The fyke nets were fished continuously for about $23 \mathrm{~h}$ following the release of test fish and then were raised for about $1 \mathrm{~h}$ to retrieve fish and to clean the nets. The nets were repositioned before the initiation of each test.

\section{STATISTICAL ANALYSIS}

Estimates are given for the percent of fish killed or descaled during the screen evaluations. The amount of time for test fish to move from their release point to the inclined plane is estimated from the hours required to capture $50 \%$ of a test group. The capture efficiency of the inclined plane and the fyke nets used during screen integrity tests are estimated using the nurber of fish captured during a test. The efficiency data are used to estimate the efficiency of the screen in preventing fish from passing from the screen forebay to the canal downstream of the screens.

\section{Descaling and Mortality Estimates}

Estimates of the percentage of fish descaled or killed were based on the number of test fish caught. Descaled fish were considered dead for evaluation of the results. The lower and unper confidence intervals. respectively, are estimated as

$$
L C I=\frac{B}{B+(n-B+1) F}
$$

and

$$
U C I=1-\frac{n-B}{n-B[n-(n-B)+1] F}
$$

where $B$ equais the number of dead or descaled fish, $n$ the number of fish caught. and $F$ a ratio of the estimates for the mean sample variance and the individual sample variance. The estimates were calculated from Mainland's Tables (Mainland et al. 1956)

Data for replicate tests were combined to obtain a mean estimate. The estimate assumes each fish behaved independently (i.e.. fish within a test did not behave more similarly than fish between tests and there were no interactions among fish within a test). Although some interaction is expected among fish, the assumption is necessary for the analytical methods used. All tests were conducted in the same manner to reduce nonindependent behavior of fish.

\section{Screen Efficiency Estimates}

Three tests with four groups of fish were conducted at Westside Ditch. screen efficiency estimates were computed for each test in addition to an 
overall estimate. Fyke nets were in place behind each screen for each test.

Two quantities are computed to estimate screen efficiency. They are inclined plane efficiency (EFFip) and net capture efficiency (EFFnc). Net retention is assumed to be equal to net efficiency at Westside Ditch. Thus, net retention equals 1. Given this, the formula for computating of screen efficiency (EFFSC) is

$$
E F F_{S C}=1-\frac{X_{\text {net }}}{E F F_{n C}}
$$

where $X_{\text {net }}$ equals the number of fish released upstream of the screens and caught in the nets, and $N$ is defined as:

$$
N=\frac{x_{n e t}}{E F F_{n c}}+\frac{x_{i p}}{E F F_{i p}}
$$

where $x_{i p}$ equals the number of fish released upstream of the screens and caught in the inclined plane. N represents of the total number of fish released into the section being estimated. For some estimates and the overall estimate, some fish are still not accounted for after the efficiencies (EFFip and $E F F_{n c}$ ) have been considered. To avoid making assumptions about what might have happened to these, an effective $N$ has been computed that is smaller than the actual number released. It must be noted that $N$ is not an actual accounting of all fish caught in different locations (inclined plane, fyke nets, bypass), but an estimate based on the actual numbers, adjusted by efficiencies for net losses and human error.

The efficiencies per set must now be defined. The input data for each section are as were explained, combining across relevant tests. The general forms are

$$
E F F_{i p}=\frac{n_{i p}}{N_{i p}} \text { and } \quad E F F_{n c}=\frac{n_{n c}}{N_{n c}}
$$

where $n_{i p}$ is the number of fish released in the bypass and caught in the inclined plane for the section being estimated. Nip is the number releaced in the bypass. $n_{n c}$ the number released in the net mouth and caught in the net, and $N_{n c}$ the number released in the net mouth.

For the overall efficiency, it should be noted that individual test efficiencies are not simply averaged: rather, the efficiency is computed by combining all data. Averaging the separate tests would assume equal numbers were released in each test and weight them as such. By computing the overall estimates from all data lumped as one test, the varying $\mathrm{N}$ values are incorporated and differences in test size are compensated. 
The confidence intervals were computed using the standard normal approximation method (Mond et a1. 1974). For a $95 \%$ confidence interval

$$
P\left[E F F_{S C}-1.96 \sqrt{\operatorname{var}\left(E F F_{S C}\right)} \leq \operatorname{true}\left[E F F_{S C}\right] \leq E F F_{S C}+1.96 \sqrt{\operatorname{var}\left(E F F_{S C}\right)}\right]=0.95 \text {. }
$$

Here EFFsc indicates our estimate while true [EFFsc] indicates the true or actual value of the screen efficiency. EFFSC is a binomial proportion, and the form for its variance is EFFSC $\left(1-E F F_{S C}\right) / N$. However, because we used efficiencies (EFFip. EFFnc. EFFnr) in the computation of EFFsc with their own inherent errors, these errors must be propagated and incorporated into the variance of EFFSC. If EFFncr is defined to be the combined catch and retain efficiency (EFFnc $\times E\left(F_{n r}\right)$, then the variance of EFFsc is

$$
\operatorname{var}\left[E F F_{S C}\right]=\left(\frac{\partial E F F_{S C}}{\partial E F F_{i p}}\right)^{2} \operatorname{var}\left[E F F_{i p}\right]+\left(\frac{\partial E F F_{S C}}{\partial x_{n e t}}\right)^{2} \operatorname{var}\left[x_{n e t}\right]
$$

where all variables are as previously defined. This formula is the first term of a Taylor's series expansion (Holman 1971). Second-order and higher order effects have been neglected. The assumption is made that EFFip and $x_{n e t}$ are independent of each other, which is reasorable in this case.

The variances of EFFip and EFFnc were computed by assuming them to be binomial proportions and using the appropriate $N$ for the section in the EFF(1-EFF)/N formula as stated previously. The variable $x_{n e t}$, the number of fish caught in the nets that were released upstream of the screens, is distributed binomial (N,EFFSC), making its variance equal to N[EFFSC (1$\left.\left.E F F_{S C}\right)\right]$. 
RESULTS

Fish that passed through the fish return pipe at the Wapato Screens or the fish bypass system at the Westside Ditch Screens were not descaled or killed. Fish were not "flushed" from the screen forebay at the westside Ditch Screens, but moved out of their own volition. The angled rotary drum screen design prevented most fish from entering the canal behind the screens at Wapato. At Westside Ditch, chinook salmon fry were able to pass through, over, or around the screens. Data are presented as they relate to the objectives of each phase outlined in the work plan (Appendix A). A detailed summary of the catch data and estimates for percentage of test fish that were descaled or killed are presented in Appendix B.

\section{PHASE I}

Phase I tests are designed to evaluate components within the fish diversion system other than the rotary drum screens. The Westside Ditch Screens fish bypass system contains no structures other than the drum screens: therefore, no Phase I tests were conducted at the Westside Ditch Screens.

\section{PHASE II}

Phase II tests evaluated either the entire fish bypass system from the trash racks through the fish return pipe (Phase IIa) or specific components of the fish return system (Phase IIb). We initiated our evaluations with Phase IIa testing at the Westside Ditch Screens. We released fish into the canal upstream of the screening facility and captured them in the inclined plane before they entered the fish return pipe. In addition to collecting fish descaling and mortality data. we determined how long released iish remained upstream of or within the Westside Ditch Screens. Phase II a and IIb tests were completed at the Wapato Screens in 1987 (Neitzel et al. 1988). Phase IIb tests were repeated at the Wapato Screens in 1989.

\section{Phase II}

Tests at the Westside Ditch Screens were conducted in late April. Two groups of branded steelhead and two groups of spring chinook salmon smolts were released in the canal upstream of the screens forebay. One group of steelhead and one group of spring chinook salmon ( 375 fish per group) were released during the morning, and two groups of fish ( 375 steelhead and 380 spring chinook salmon) were released in the evening. Of the groups released in the morning. 304 steelhead (81.1\%) and 371 spring chinook salmon (98.9\%) were captured on the inclined plane in the fish return during the next $96 \mathrm{~h}$. Of the fish released in the evening. 321 steelhead $(85.6 \%)$ and 379 spring chinook salmon. (99.7\%) were caught in the following $75 \mathrm{~h}$. A total of 625 steelhead and 750 spring chinook salmon were examined for descaling, and 11 steelhead (1.8\%) and 2 spring chinook salmon (0.3\%) were descaled (Table 1 ). The descaling rates of $1.8 \%$ for steelhead 
and $0.3 \%$ for spring chinook salmon were we1l within the $95 \%$ confidence intervals for the condition controls (Appendix B). None of 104 steelhead and 204 spring chinook salmon held for $96 \mathrm{hr}$ to monitor delayed mortality died.

The downstream movement of steelhead and spring chinook salmon released for descaling evaluations was monitored each half-hour as the fish appeared on our sampling plane in the fish return. The movement rate for steelhead (Figure 8. Table 2) indicates that salmonid smolts are not flushed from the Westside Ditch Screens forebay: rather. they move through the screen forebay of their own volition. Spring chinook salmon exited the screens forebay quickly (Figure 9, Table 2).

\section{Phase IIb}

Because test fish were more easily captured at the flow control structure, the potential effect of passage through the fish return pipe was evaluated separately at the Wapato Canal. Because this was a test of a specific component of the fish return system. test results are presented as Phase I Ib data.

Three groups of 50 spring chinook salmon were released at the head of the Wapato Screens fish return pipe. All of the fish were captured and evaluated for descaling, and none of the fish were descaled (Table 3 ).

\section{PHASE III}

Phase III tests at the Wapato Screens were completed in 1987 (Neitzel et al. 1988) and were repeated this year. Tests at the Westside Ditch Screens were conducted about 1 week after the canal was filled, and flows were al ready near the maximum for the canal. No Phase III tests were conducted at the Westside Ditch Screens. Because operating criteria have not been formally submitted. we decided that the most meaningful data would result from tests where the canal is operated at near capacity.

\section{PHASE IY}

The inclined plane was used during release and capture tests to note the presence of predatory fish and the occurrence and condition of native salmonids. The drum screens were monitored to determine if fish were impinged. Rainbow trout fingerlings were released at the Westside Ditch Screens to test for possible passage through, around, or over the rotary drum screens. Additionally. passage of native chinook salmon fry was monitored. 


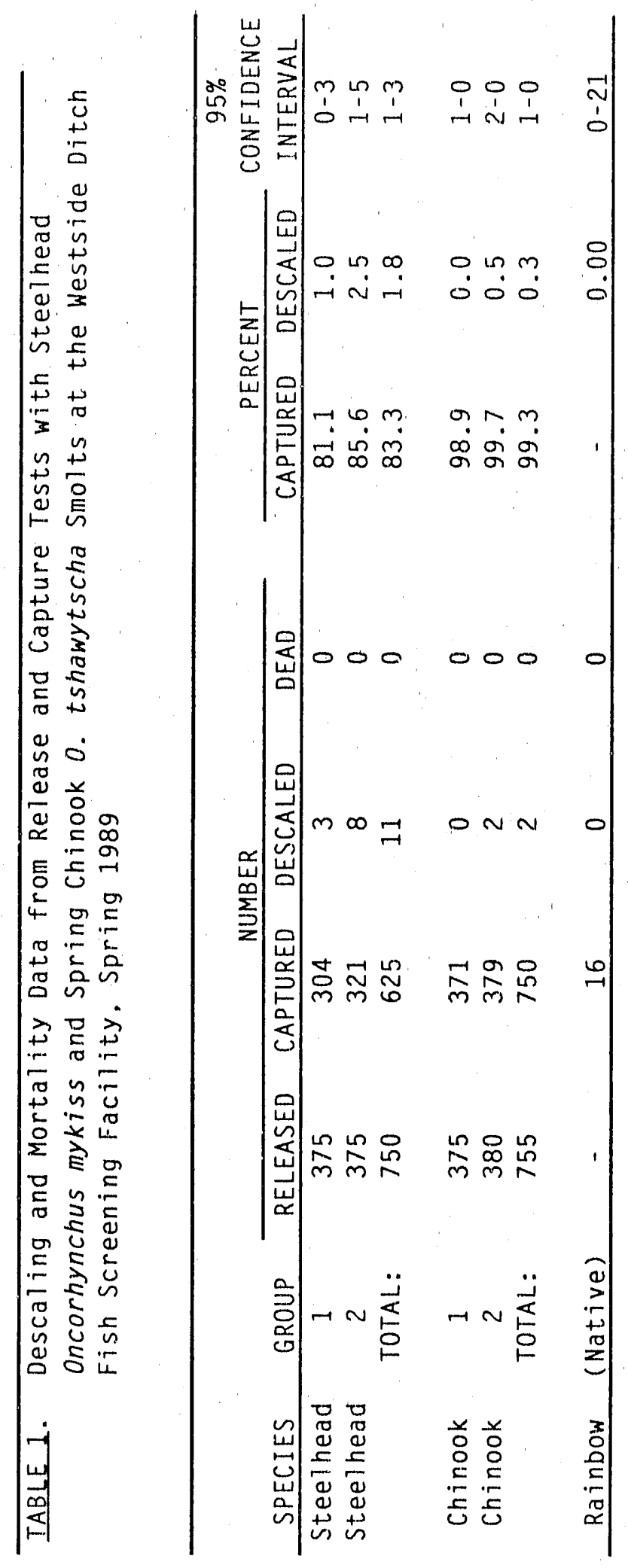




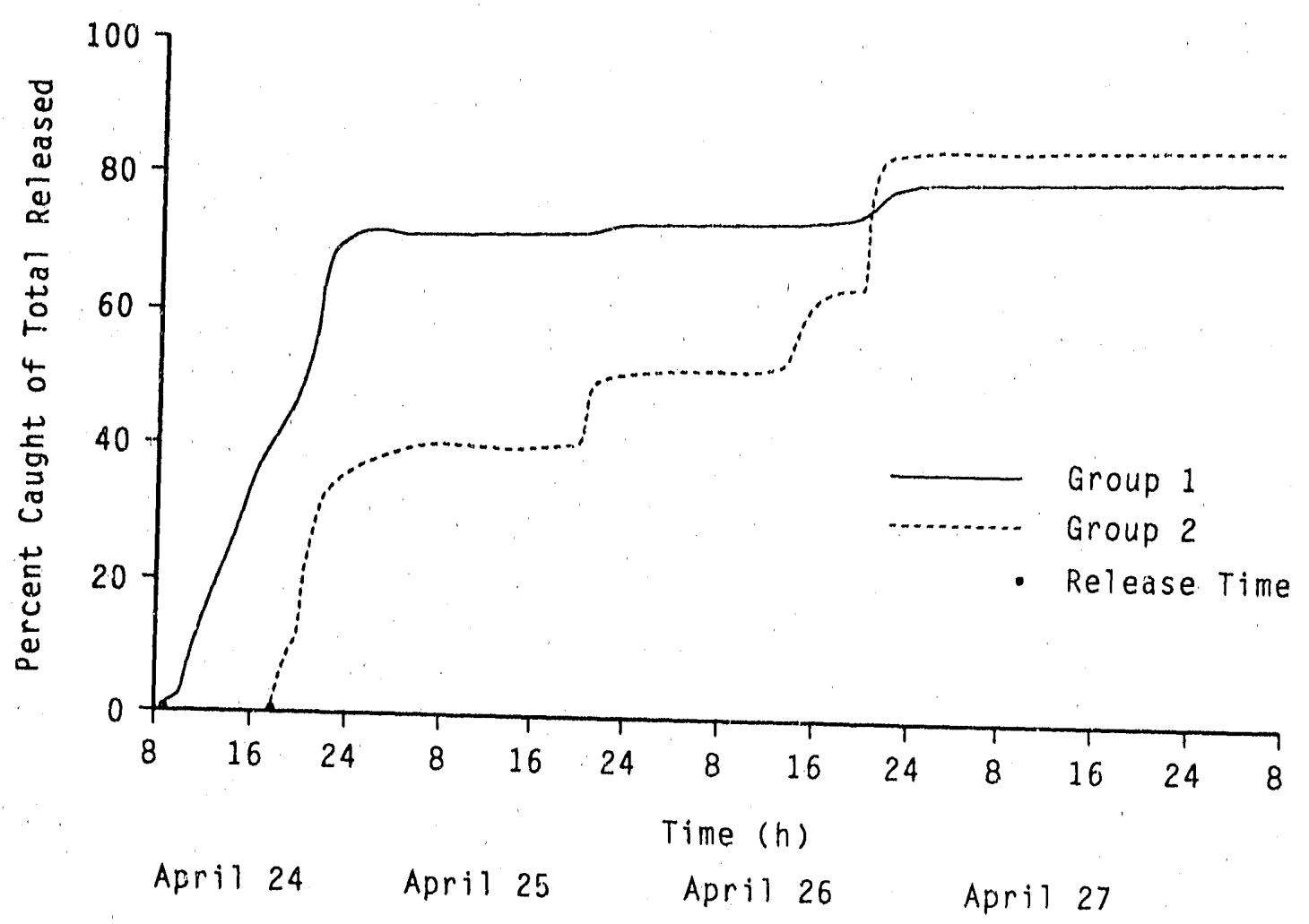

EIGURE 8. Movement of Steelhead Oncorhynchus mykiss Smolts Based on the Capture of Test Fish at the Westside Ditch Canal Fish Screening Facility. Spring 1989

\begin{tabular}{|c|c|c|c|c|c|}
\hline$\triangle A B L E 2$. & $\begin{array}{l}\text { Estimated T } \\
\text { and Spring } \\
\text { Descaling Te } \\
\text { Facility. Sp }\end{array}$ & $\begin{array}{l}\text { O Capture } \\
\text { ok Salmori } \\
\text { at the Wes } \\
1989\end{array}$ & $\begin{array}{l}\text { Steel } \\
\text { hawytsc } \\
\text { Ditch }\end{array}$ & $\begin{array}{l}\text { Oncorhyr } \\
\text { nolts Rel } \\
\text { I Fish So }\end{array}$ & $\begin{array}{l}\text { 1s mykiss } \\
\text { sed in } \\
\text { aning }\end{array}$ \\
\hline \multirow[b]{2}{*}{ SPECIES } & \multirow[b]{2}{*}{ GROUP } & \multicolumn{2}{|c|}{ NUMBER } & \multirow{2}{*}{$\begin{array}{r}\text { PERCENT } \\
\text { CAUGHT }\end{array}$} & \multirow{2}{*}{$\begin{array}{l}\text { TIME (h) } \\
\text { TO CATCH } \\
50 \%\end{array}$} \\
\hline & & RELEASED & CAUGHT & & \\
\hline Steel head & $\begin{array}{l}1 \\
2\end{array}$ & $\begin{array}{l}375 \\
375\end{array}$ & $\begin{array}{l}304 \\
321\end{array}$ & $\begin{array}{l}81.1 \\
85.6\end{array}$ & $\begin{array}{l}12.5 \\
28.1\end{array}$ \\
\hline $\begin{array}{l}\text { Chinook } \\
\text { Chinook }\end{array}$ & $\begin{array}{l}1 \\
2 \\
\end{array}$ & $\begin{array}{l}375 \\
380 \\
\end{array}$ & $\begin{array}{l}371 \\
379 \\
\end{array}$ & $\begin{array}{l}98.9 \\
99.7 \\
\end{array}$ & $\begin{array}{l}3.3 \\
7.8 \\
\end{array}$ \\
\hline
\end{tabular}




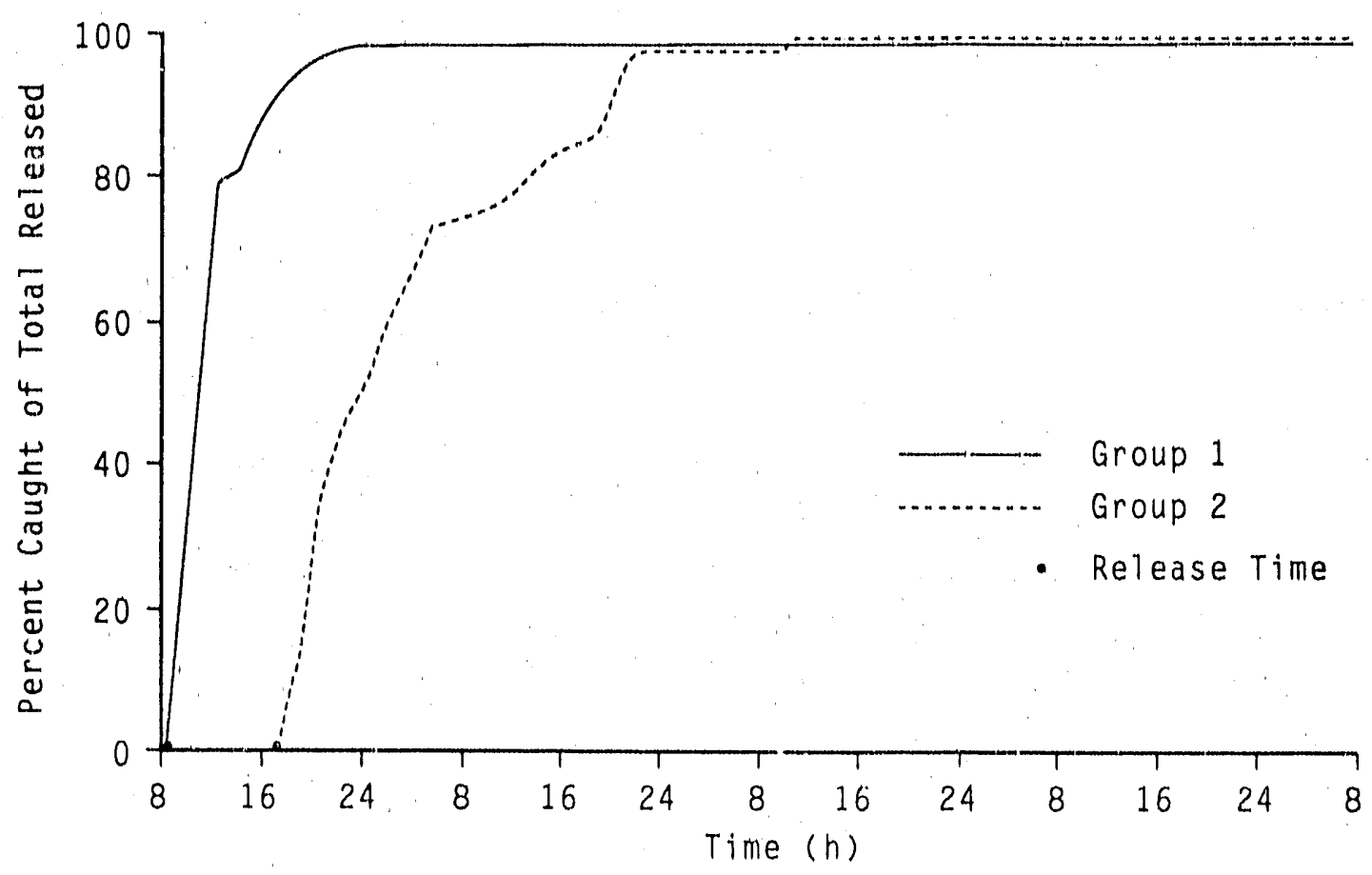

$\begin{array}{llll}\text { April } 24 & \text { April } 25 & \text { April } 26 & \text { April } 27\end{array}$

EIGURE 9. Movement of Spring Chinook Salmon Oncorhynchus tshawytscha Based on the Capture of Test Fish at the Westside Ditch Canal Fish Screening Facility. Spring 1989

TABLE 3. Percentage of Spring Chinook Salmon Oncorhynchus tshawytscha Smolts Descaled In Pipe Tests at the Wapato Canal Fish Screening Facility, Spring 1989

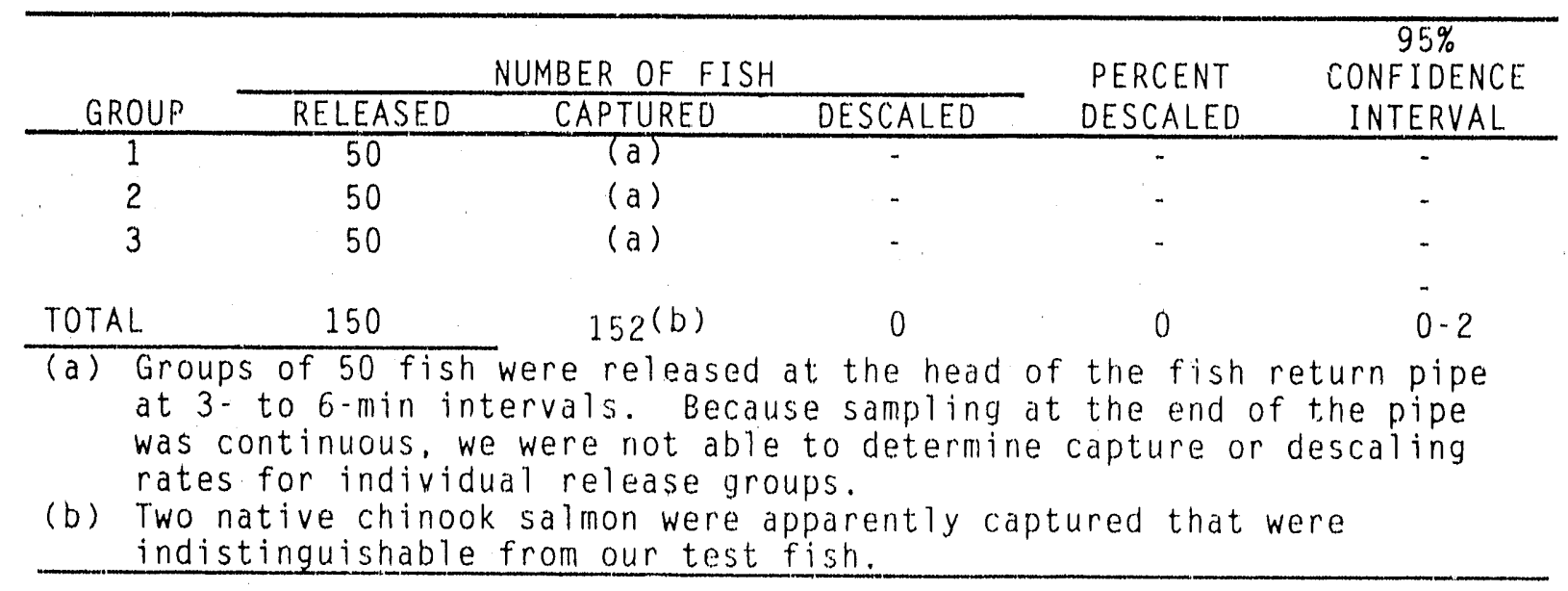




\section{Phase IVa}

Few native juventle salmonids were captured durtng tests at the westside Ditch Screens: however, chinook salmon fry $(<A O \mathrm{~mm} F L)$ were common. None of the 16 juventle rainbow trout and/or steelhead and 1 sping chinook smolt we caught were descaled. The rainbow trout had not developed typical smolt characteristics and probably were not stenlhead. Northern squawfish Ptychocheilus oregonensis and one yellow perch Perca flavescens were caught on the inclined plane during our tests, but no fish were found in their stomach contents.

\section{Phase IVb}

A total of 3143 rainbow trout fry $(49.3 \mathrm{~mm} F L)$ were released in front of the screens and 2000 fry were released in the fyke nets behind the screens to evaluate screen effectiveness in preventing fish from entering the canal behind the screens. Of $3143 \mathrm{fish}$ released in front of the screens, 508 $(16.2 \%)$ were recovered in the fish return and $22(0.8 \%)$ were recovered in fyke nets (Table 4). Of the 1200 branded rainbow trout fry $(49.3 \mathrm{~mm} F L$ ) and 800 unmarked fry $(36.6 \mathrm{~mm} F L)$ released in fyke nets behind the drum screens, $714(59.5 \%)$ and $523(65.4 \%)$, respectively, were recovered from the fyke nets.

In addition to our test fish. 133 chinook salmon fry were caught in fyke nets behind the screens, compared to 650 fry caught on the inclined plane in the fish return during the same periad (Table 5). Most of the chinook salmon fry caught on the inclined plane were captured at night. Fry were captured in fyke nets behind all four drum screens (Table 5).

The unmarked rainbow trout fry released in the mouths of fyke nets for the last two screen integrity tests were similar in girth but shorter than the chinook salmon fry. Capture rates for the small rainbow was similar to capture rates for the larger marked rainbow trout. Capture efficiency of the fyke nets varied from $56 \%$ to $79 \%$ (Table 6 ).

Based on the number of fish caught on the inclined plane and the capture efficiency of the fyke nets, about $6.0 \%( \pm 0.35)$ of the rainbow trout released in front of the drum screens passed over, around, or through the drum screens. The 133 fall chinook fry captured in the fyke nets represented $17.0 \%$ of the total number of fry observed during our sampling period. When the fyke net capture efficiency for rainbow trout is applied to the chinook salmon capture data, we estimate $24.8 \%( \pm 0.35)$ of chinook salmon fry in Westside Ditch passed over, around, or through the drum screens.

Approximately $83 \%$ of the rainbow trout fry that we planted in front of the screens were not recovered. Rainbow trout fry were not flushed from the Westside Ditch Screens forebay. Most of the fry held in the screens 


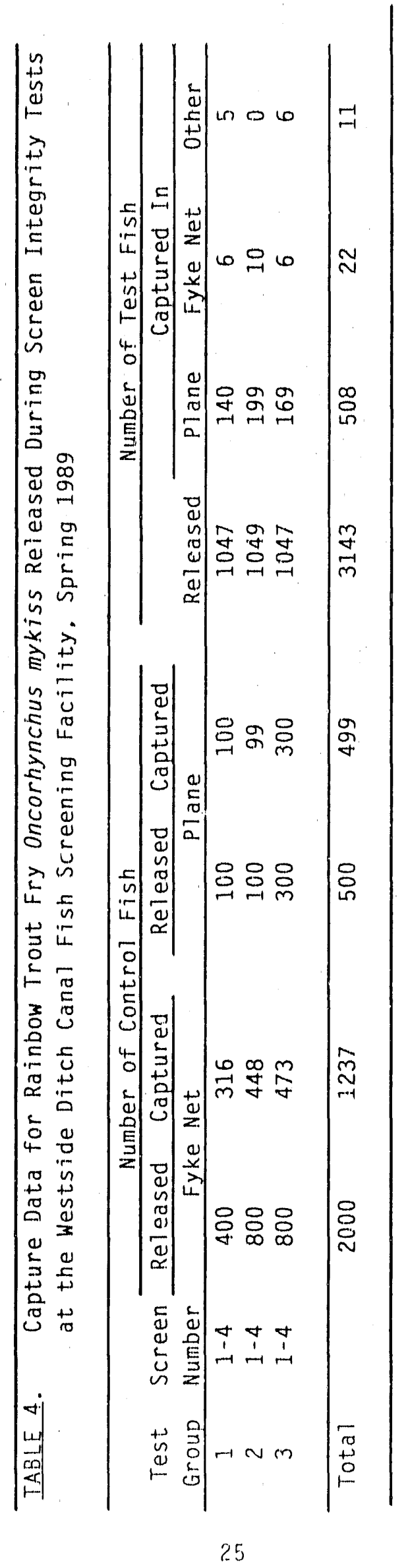




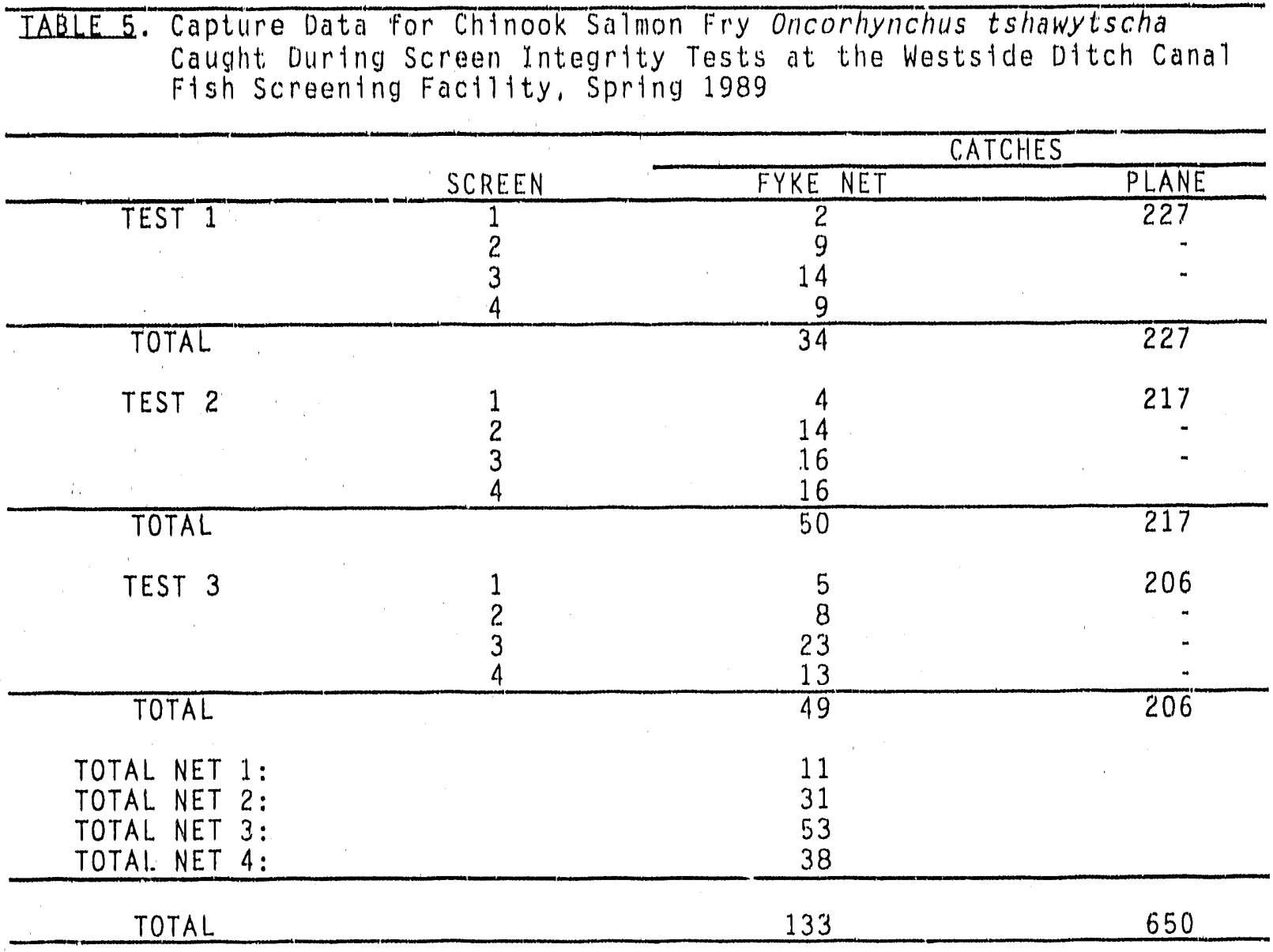

\begin{tabular}{|c|c|c|c|c|}
\hline $\begin{array}{r}\text { TABLE 6. Capt } \\
\text { Durt } \\
\text { Scre }\end{array}$ & $\begin{array}{l}\text { ture Efficiency } \\
\text { ing Screen Integ } \\
\text { eening Factitty. }\end{array}$ & $\begin{array}{l}\text { the Incline } \\
\text { ty Tests at } \\
\text { pring } 1989\end{array}$ & $\begin{array}{l}\text { ane and FJ } \\
\text { Weststde }\end{array}$ & $\begin{array}{l}\text { ts Used } \\
\text { Canal Fish }\end{array}$ \\
\hline TEST & $\frac{\text { CAPTURE PROBAB }}{\text { INCLINED PLANE }}$ & $\frac{\text { ITY ESTIMATE }}{\text { FYKE NET }}$ & $\begin{array}{c}\text { SCREEN } \\
\text { EFFICIENCY }\end{array}$ & $\begin{array}{c}95 \% \\
\text { CONFIDENCE } \\
\text { INTERVAL }\end{array}$ \\
\hline $\begin{array}{l}\text { Rainbow } \\
1 \\
2 \\
3\end{array}$ & $\begin{array}{r}\text { Trout } \\
1.000 \\
0.990 \\
1.000\end{array}$ & $\begin{array}{l}0.790 \\
0.560 \\
0.591\end{array}$ & $\begin{array}{l}0.949 \\
0.918 \\
0.943\end{array}$ & $\begin{array}{l}0.91-0.99 \\
0.86-0.98 \\
0.89-1.00\end{array}$ \\
\hline Total & 0.998 & 0.619 & 0.935 & $0.90-0.97$ \\
\hline $\begin{array}{l}\text { Chinook } \\
1 \\
2 \\
3\end{array}$ & $\begin{array}{r}\text { Sa } 1 \mathrm{mon} \\
1.000 \\
0.990 \\
1.000\end{array}$ & $\begin{array}{l}0.790 \\
0.560 \\
0.591\end{array}$ & $\begin{array}{l}0.841 \\
0.711 \\
0.713\end{array}$ & $\begin{array}{l}0.79-0.89 \\
0.65-0.78 \\
0.65-0.78\end{array}$ \\
\hline Total & 0.998 & 0.619 & 0.752 & $0.72-0.79$ \\
\hline
\end{tabular}


forebay: however, some fish were lost to predation by our test fish. Fish from each of the three release groups were caught throughout the duration of sampling. with movement increasing at suriset (Figure 10).

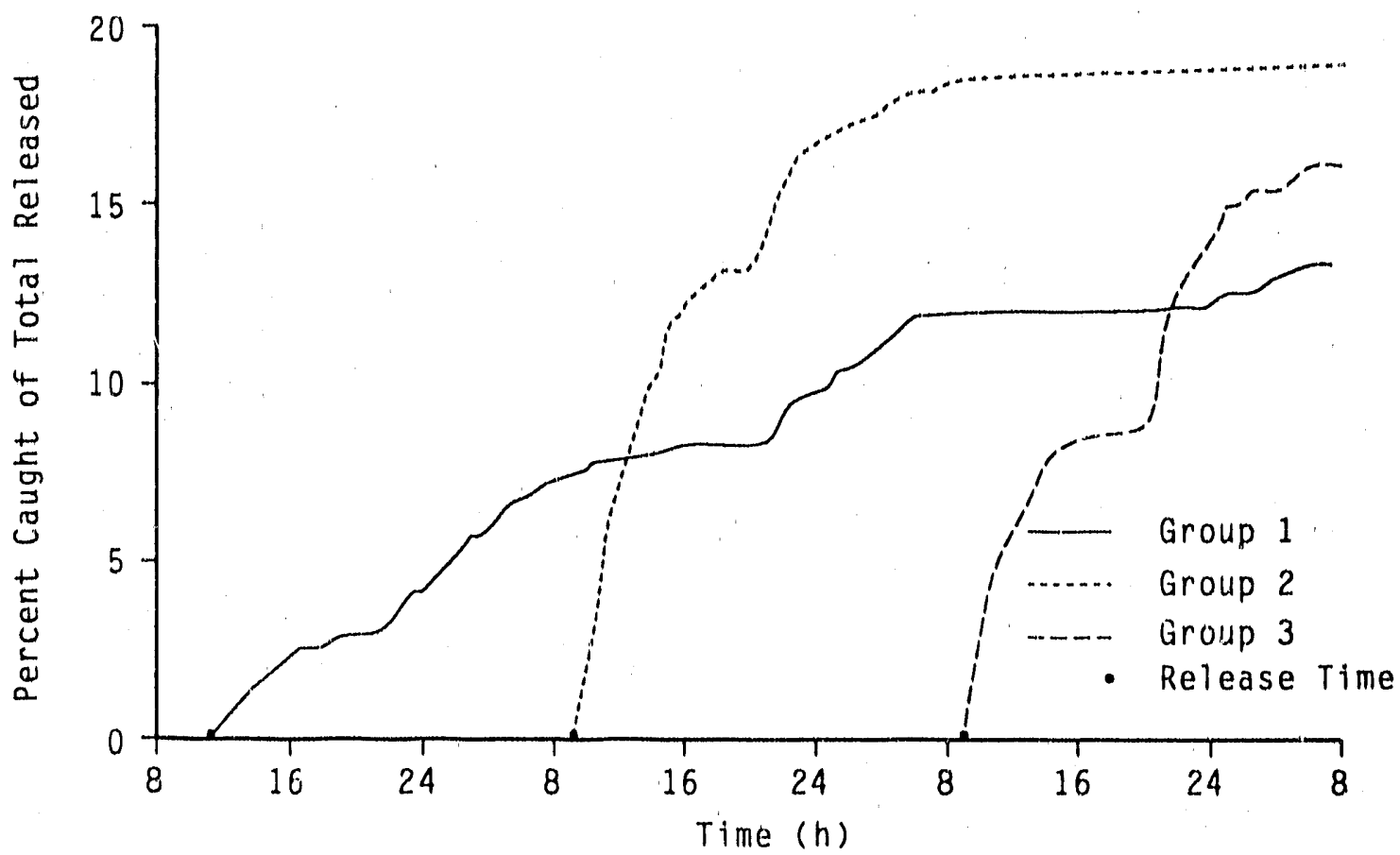

Apri1 25

April 26

April 27

EIGURE 10. Movement of Rainbow Trout Oncorhynchus mykiss Fry Based on the Capture of Test Fish in the Bypass During Screen Integrity Tests at the Westside Ditch Canal Fish Screening Facility. Spring 1989 


\section{DISCUSSION}

Fish screenting factlittes in the Yaktma Basin are destgned to direct fish that have been diverted from the river into irrigation canals back to the river without klliing or injuring them or delaying their migration. The work plan for this study was destgned to determine if the diverted fish can be safely and expeditiously returned to the river. Tests following the work plan were conducted to: 1) evaluate the conditions or clrcumstances that affect fish survival as the fish pass through the screening facflity. 2) determine if a screening factlity provides conditions under which diverted fish may become more susceptible to predation. 3 ) evaluate whether fish are delayed at or upstream of the screenting factlities, and 4) determine if fish pass through, around, or over rotary drum screens and become trapped in the irrigation canal.

\section{EISH SURVIVAL AT SCREENING FACILITIES}

Based on release/capture tests at six screening factlities, fish are not descaled or kllled during passage in front of the rotary drum screens or through the fish bypass systems. As in previous descaling evaluations at the Sunnyside, Richland. Toppenish/Satus, Toppenish Creek, and Wapato Screens, the descaling rate for test fish at the Westside Ditch Screens within the confidence limits for control fish.

Fish were not injured from passing through the fish return pipe at the Wapato Canal Fish Screening Facility. The small descaling rate observed in previous tests of the fish return pipe (Neitzel et al. 1988) was the product of the collection technique and equipment. No descaling was observed due to passage through the pipe or from the collection equipment in tests conducted this year.

\section{POTENTIAL FOR PREDATION AT SCREENING FACILITIES}

On the basis of the samples we have collected. loss to predation does not appear to be a problem at screening facilities when only native species are involved. However, hatchery-released salmonids that take up temporary residence in a screens forebay may increase predation pressure at screen sites. Screening facilities could affect the predator/prey relationship if the screens concentrate prey or increase the exposure of prey to predators because of stress, injury. or delay in migration.

\section{Weststde Ditch Screens}

No predation was observed at the Westside Ditch Screens, although some rainbow trout fry released for Phase IVb tests were consumed by steelhead smolts we released for Phase IIb tests. Predation, therefore, appeared to 
be related to the artifictal and temporary predator/prey population structure created by the release of our test fish. Although many chinook salmon fry were caught during tests at the Westside Ditch Screens, few smolt-size salmonids were caught. indicating that the smolts had already migrated from the reach of the Yakima River upstream of the Westside Ditch Canal or that juventle salmon do not overwinter in the reach. Regardless. the natural predator/prey population structura in the screens forebay should be similar to that in the Yakima River because fish movement through the screens forebay is not impaired when adequate bypass flows are provided.

\section{POTENIIAL FOR FISH DELAY AI SCBEENING FACILITIES}

One of the basic objectives of redesigning and constructing new screens is to provide factlities that safely and rapidly return fish from diversion canals to the river (Easterbrooks 1984). Fish are not "flushed" from the screen forebay back to the river. although the screening facllitiles do not impede voluntary movement and migration under normal operating conditions. Conversely. inadequate bypass flows resulting from improper operation. inoperable components in the bypass system. low canal flows or forebay elevations, or blockages in the fish return can impair the movement of fish through the fish bypass system and contribute to delays in migration.

Flow through the fish return pipe at the westside Ditch Screens was severely restricted before we initiated our tests. Normal fish bypass flows were not attainable because the fish return slot was backed up with water. In the week preceding our tests, we observed several small chinook salmon fry holding in the fish return slot. The head of the fish return pipe was plugged with debris that either washed into the fish return slot when the canal was filled or was not removed before startup. Besides restricting water flow and fish movement, a partially plugged pipe would injure fish.

\section{EISH PASSAGE THROUGH OR OVER ROTARY DRUM SCREENS}

The sweeping to approach velocity ratio designed into the facilities helps to guide fish into the fish bypass, and screen mesh openings $(3.2 \mathrm{~mm}, 1 / 8$ in.) are small enough to prevent most salmonid fry from passing through the drum screens. Tests were designed and accomplished at the westside Ditch Screens to determine if any fish might be impinged by or passed over. around or through the drum screens.

\section{Westoide Ditch Screens}

Fish released in the screens forebay were caught in fyke nets behind all four of the drum screens. Some of the fish caught behind the screens were the result of "rollover" of fish released at the water surface near the 
screen face. However, rollover accounced for only a sinall percentage of the total number of fish caught behind the screens. The passage rate for chinook salmon fry. was four times greater than for our test fish. and was due either to the smaller size of the chinook saimon or to a difference in behavior. No rollover was observed for chinook salmon fry. However, the fish moved at night when rollover observations are difficult.

The 1/8-in. screen mesh used in the construction of the drum screens at the Westside Ditch Canal and most other screening facilities is believed to be small enough to prevent salmonid fry from passing through the mesh. However, the smaller chinook salmon fry captured in the fyke nets behind the drum screells could be "pushed" through the mesh without apparent injury. Chinook salmon fry 32 to $40 \mathrm{~mm}$ in length could not pass through a 5/32-in. screen opening (Fisher 1978): however, the tests were conducted with perforated plate, and not with the coarse woven wire mesh used in the construction of ine drum screens.

Fish potentially can pass around the drum screens at Westside Ditch. Although the seals around the circumference at each end of the screens appear tight. small gaps around the end frames of the drum screens are evident. 
Release and capture tests and other monitoring studies have been conducted at six diversion screen facilities in the Yakima Basin: the Sunnyside Screens (Neitzel et al. 1985), the Richland and Toppenish/Satus Screens (Neitzel et al. 1986), the Wapato Screens (Neitzel et al. 1988), the Toppenish Creek Screens (Neitzel et 21. 1989), and the Westside Ditch Screens. The objective of our evaluations was to determine whether or not fish that have entered a irrigation canal are safely diverted back to the river. The objective was met by determining if: 1) fish that pass through the diversion are killed, injured, or eaten by predators; 2 ) fish migratio! is delayed at the screen structure; and 3 ) fish are prevented from passing through or over the screens. These objectives are addressed in the various phases of the work plan.

\section{PHASE I}

Phase I tests conducted at the Sunnyside Screens in 1985 used chinook salmon and steelhead smolts. The test data indicated that fish safely pass through all components of the fish bypass system. No Phase I tests have been conducted at the Richland. Toppenish/Satus. Toppenish Creek, or Westside Ditch Screens, because the fish bypass systems did not incorporate intermediate and terminal bypasses, traveling screens, or fish water pumpback systems in their designs. No Phase I tests were conducted at the Wapato Screens, because none of the components of the fish passage facility differed significantly from components at the Sunnyside Screens, which were proven safe for fish passage.

\section{PHASE II}

Phase IIa tests have been completed at all six screening facilities. At the Sunnyside Screens, fish were released either at the trash racks or the head gates. Fish captured after moving through the screen forebay and diversion system were not injured or killed. At the Richland. Toppenish/Satus, Wapato, and Toppenish Creek Screens, fish were released only at the trash racks, and fish were released in the canal upstream of the screens at the Westside Ditch Screens. Captured fish were not killed or injured. Tests at the Sunnyside. Wapato. Richland, and Westside Ditch Screens were conducted with chinook salmon and steelhead smolts. Tests at the Toppenish/Satus and Toppenish Creek Screers were conducted with steelhead smolts only.

Phase IIb tests have been conducted at the Sunnyside. Richland. Toppenish Creek, and Wapato Screens. At Sunnyside, tests were conducted to evaluate the intermediate bypass system, the terminal bypass system, the secondary separation chamber, and the primary fish return pipe. At the Richland. 
Toppenish Creek, and Wapato Screens, the fish return pipe was evaluated. Fish successfully passed through each of the components without injury or delay.

\section{PHASE III}

Phase III tests have been conducted at the Richland. Toppenish Creek, and Wapato screens. Pipe tests were conducted under two bypass flows at the Richland Screens. Fish were not injured or killed at either bypass flow. Evaluations at the Toppenish Creek and Wapato Screens were conducted during low and full canal flow conditions. Fish were not injured or killed in either test; however. movement rate was slower during low canal flow conditions. Opportunities to conduct tests under different canal flows have been limited because of delays in construction and startup at the Sunnyside, Richland, and Toppenish/Satus Screens. The Sunnyside, Toppenish/Satus, and Westside Ditch Screens were evaluated only at full canal flow conditions and the Richland Screens only at minimum flow conditions.

\section{PHASE IV}

Native fish were collected during all bypass tests and the gut contents of predacious fish were examined. Predacious bird activity was also monitored in the vicinity of each screening facility. Increased predation does not occur at screening facilities, except that hatchery-released salmonids sometimes congregate in the screens forebay and prey on salmonid fry.

Rotary drum screens were examined during bypass tests to determine if any fish were impinged on or passed over the screens. Successful screen integrity tests have been completed at the Richland. Toppenish Creek. Sunnyside. Wapato, and Westside Ditch Screens. The Richland Screens are effective at preventing fish from entering the irrigation canal: however, some fish passed over the screens and through faulty screen seals at the Toppenish Creek, Sunnyside, Wapato, and Westside Ditch Screens. Screen integrity tests initiated at the Toppenish/Satus Screens were not completed because we did not have nets to capture fish downstream of the rotary screens. 


\section{RECOMMENDATIONS}

Fisheries evaluations have been conducted at six diversion screen facilities: the Sunnyside, Richland. Toppenish/Satus, Wapato, Toppenish Creek, and Westside Ditch Screens. Data were collected to address five areas of concern: fish survival, predation, migration delays, screen passage, and effects of operating conditions. The results of tests addressing each concern were integrated to evaluate the effectiveness of the screens.

The data indicate that fish are not descaled or killed as they are diverted by the screening facilities; however, descaling tests should continue at future diversion sites to assess potential site-specific problems. Emphasis should be placed on correlating descaling to canal operations (Phase III). The periods when canal operating conditions are of greatest concern are 1) during canal startup and 2) during peak migration of native salmonid stocks in the vicinity of each screening facility.

Increased predation does not seem to occur at screening facilities, except when hatchery-released salmonids sometimes congregate in the screens forebay, and prey on salmonid fry. The potential impact of predation in the screen forebays can only be assessed if predation in the screen forebay is compared to predation in the river.

Fish successfully pass through the screen facilities of their own volition. Fish are not "flushed" from the screen forebays and can remain in the forebays. The potential impact of migration delay in the screen forebays can only be assessed when migration timing through the screen forebays is compared to migration timing in the river.

Tests to evaluate screen integrity should continue to have high priority. The screen integrity tests we completed at the Toppenish Creek. Sunnyside, Wapato, and Westside Ditch Screens indicate that screen seals play a vital role in preventing fish from entering the irrigation canal. Annual inspection and replacement of screen seals might reduce losses; however, a new seal design may be necessary if the present loss rate is not acceptable.

Monitoring of chinook salmon fry should be conducted at the Westside Ditch Screens after the problems with end seals have been resolved. The Department or Fisheries has suggested that the frames be "crowded" upstream in the structure blockouts and wedged to close the gaps before the canal is filled.

The wire mesh used for the construction of drum screens should be tested to verify that fish can not pass through the mesh. Chinook salmon fry captured in future screen evaluations could be used as test fish. 
The fish bypass systems are operated following criteria for flows through the flow control gates, fish return pipes, and other bypass structures. These operating conditions are set to protect fish that move through the system. It is imperative that the operating conditions are adhered to when fish are moving through the diversions. Operating conditions need to be published and should cover all operating conditions for each facility. Facility structures, such as water elevation markers, must be installed at all facilities so operating criteria can be properly implemented.

The fish bypass system should be thoroughly checked and calibrated at each screening facility at the beginning of each irrigation season. Operating criteria should stress that fish bypass flow is very important in achieving effective fish bypass. Fish are not involuntarily delayed at or within the screening facilities when bypass flows are set according to the operating criteria and properly maintained. Debris that blocked the head of the fish return pipe at the Westside Ditch Screens resulted in reduced bypass flows and was a potential site for injury to fish. 


\section{REFERENCES}

Basham, L. R., M. R. Delarm, J. B. Athern, and S. W. Pettit. 1982. Fish Iransportation oversight Team Annual Report. FY 1981: Transport operations on the Snake and Columbia Rivers. Technical Services Division. Northwest Regional Office. National Oceanic and Atmospheric Administration. National Marine Fisheries Service, Portland, Oregon.

Bureau of Reclamation. 1984. Einding of No Significant Impact: Fish Passage and Protective Facilities, Yakima Biver Basin. Washinaton. Bureau of Reclamation. Pacific Northwest Region, Boise. Idaho.

Easterbrooks. J. A. 1984. Juvenile Fish Screen Destgn Criteria: A Review of the Objectives and Scientific Data Base. State of Washington Department of Fisheries, Habitat Management Division, Yakima. Washington.

Fast, D., J. Hubble, and B. Watson. 1986. Yakima River Spring Chinook Enhancement Study Fisheries Resources Management. Yakima Indian Nation. Prepared by the Division of Fisheries, Yakima Indian Nation, for the Bonneville Power Administration. Portiand, Oregon.

Fisher. D. W. 1978. Protection of of King Salmon and American Shad with Perforated Plate and Wire Mesh Screens. California Fish and Game, 78 " 18. Sacramento, California.

Hollowed. J. J. 1984. 1983 Yakima River Fall Fish Counts at Prosser Dam. Yakima Indian Nation. Fisheries Resource Management Technical Report No. 84-11, Yakima Indian Nation. Toppenish. Washington.

Holman. J. P. 1971. Experimental Methods for Engineers. McGraw-Hi11. New York.

Mainland, D., L. Herrera, and M. I. Sutcliffe. 1956. Tables for Use with Binomial Samples. Mainland. Herrera, and Sutcliffe, New York.

Mood. A. M., F. A. Graybill, and D. C. Boes. 1974. Introduction te the Iheory of Statistics. McGraw-Hill, New York.

Neitze1, D. A., C. S. Abernethy, and E. W. Lusty. 1990. A Fisheries Evaluation of the Toppenish Creek. Wapate and Sunnyside Fish Screening Eacilities Spring 1988. Prepared by the Pacific Northwest Laboratory. Richland. Washington, for the Division of Fish and Wildlife. Bonneville Power Administration. Portland, Oregon.

Neitze1, D. A., C. S. Abernethy, E. W. Lusty, and S. J. Wampler. 1988. A Eisheries Evaluation of the Richland and Wapato Canal Fish Screenina Facilities. Spring 1987. Prepared by the Pacific Northwest Laboratory. Richland. Washington, for the Division of Fish and Wildiife. Bonneville Power Administration. Portland, Oregon. 
Nettze1, D. A., C. S. Abernethy, and E. W. Lusty. 1986. Afisheries Evaluation of the Richland and Toppenish/Satus Canal Fish Screening Eacilities. Spring 1986. Prepared by the Pactfic Northwest Laboratory. Richland, Washington for the Division of Fish and Wildlife, Bonneville Power Administration. Portland, Oregon.

Neitze1, D. A., C. S. Abernethy, E. W. Lusty, and L. A. Prohammer. 1985. A Fisheries Evaluation of the Sunnyside Canal Eish Screening Facility. Spring 1985. Prepared by the Pacific Northwest Laboratory. Richland. Washington, for the Division of Fish and Wildlife, Bonneville Power Administration, Portland, Oregon. 
APPENDIX A

WORK PLAN

The work plan for all BPA funded screen evaluations includes four phases. Phases I through III are mark/release studies to determine changes in fish condition and transit time through the screen factlities. Phase IV is a monitoring study to determine presence of predators near the screen facilities, passage through the diversions into the canals, and arrival times at the screen facilities for migrating populations of fish.

The work plan addresses a generic facility (i.e.. head gates, trash rack, screens, fish-water-pumpbark system, separation chamber, and fish return pipe). Some of the facility components may be different or not used at a given facllity; however, the four-phase concept wl11 be applied as much as possible. Additionally, it is not always possible to implement all phases at all sites. The most important data needed to evaluate a specific screen site are determined by the fisheries management agencies in the Yakima Basin. This decision then determirles the phase of the work plan to be implemented first at a site.

\section{PHASE I}

Phase I tests are conducted to determine the condition of fish after passage through the fish diversion components of the screen facility. Phase I is accomplished by releasing branded fish at the entry to the fish bypass system. Released fish are collected near the terminus of the fish return pipe. The percentage of descaling, the number of fish killed (both immediately and after 4 days), and the rates and extent of injuries are recorded.

Several collection systems are considered, including a net at the terminus of the primary fish return pipe and a modified inclined plane or net near the terminus of the diversion system. The collection system is chosen after a site-specific evaluation of the screen facility. Collection systems are tested to determine their effectiveness and to make sure collected fish are not being injured or stressed by the system. These tests are conducted by releasing fish in and near the collection system. Effictency and handling tests are conducted throughout the evaluation tests.

Collection of released fish begins immediately on release. Collection duration and interval varies with the site and the test objective. Where the primary objective is to estimate the proportion of the released fish that are killed or descaled. we fish until we get a $95 \%$ confidence interval estimate that is acceptable. When we are estimating the travel time through a component of the screen facility, we use a similar criterion for 
developing a sample duration. Samples are collected continuously. If possible, during the first 24 to 48 h after release. If a higher catch total is required after $48 \mathrm{~h}$, collection will be made to the period of highest probable catch for the next $48 \mathrm{~h}$.

A hypothesis as to the fate of the noncollected fish for each release will be developed on the basis of the catch efficiency data that we collect during the control tests, the duration of the sample effort, and data from replicate tests when available.

Expected results from Phase I data include 1) the percentage of fish that are killed or descaled during passage through the fish bypass system in the screen diversion, 2) the change in condition for the fish that survive passage through the bypass. 3) a hypothesis as to the fate of the noncollected fish, 4) the potential effects of sampling equipment, and 5) the handling effects of the mark, release, and capture techniques.

\section{PHASE IL}

Phase II tests are conducted to determine the condition of fish after passage from upstream of the trash racks through the bypass system (Phase IIa) or after passage through individual fish passage components of the screen facility (Phase IIb). The choice of which test to use depends on whether or not fish are killed or injured during Phase I. If there are no mortalities or injuries after passage through the bypass system during Phase I. Phase Ila follows Phase I. If there are mortalities or injurtes during Phase I. Phase IIb follows Phase I.

Phase IIa.

If no effect is observed in Phase I. the condition of fish that pass through the screen facility (from upstream of the trash racks through the bypass) is determined. The spectes tested is the same as used in Phase I, if possible.

Fish are released at the trash rack. Fish are collected at the terminus of the fish return pipe. The percent descaling, the number killed (immediately and after 4 days), and the rates and extent of injuries are noted. Releases are made in and near the collection system to determine collection efficiency and handing effects.

Study objectives addressed are 1) the condition of fish that enter the headworks of the canal and are subsequently returned to the river through the primary fish return pipe and 2) transit time from the trash racks to the river discharge.

Expected results from these data include 1) the change in condition for fish that pass through the entire fish diversion and are returned to the 
river, 2) a hypothesis as to the fate of noncollected fish. 3) the transit time for fish through the facllity, and 4) collection efflctency and handling effects.

Phase IIb.

If an effect is observed in Phase $I$, the condition of fish that pass through individual components of the fish bypass system. including the intermediate bypass pipe, the secondary separation chamber, the traveling screens, and the primary fish return pipe. will be determined. The specie!s tested are the same as used in Phase I. if possible. The number released are determined by using the same criteria used in Phase I.

Fish are released in individual components of the bypass system. The fish are collected at the terminus of the component or at the terminus of the primary fish return pipe, depending on the data needed and the possibility of sampling within the component.

Study objectives addressed are condition of fish at the discharge. condition of fish through the bypass and secondary separation chamber. transit time across the facllity, and transit time through the secondary separation chamber.

Expected results from these data include identification of 1 ) a hypothesis as to the fate of noncollected fish. 2) the bypass components that adversely affect the condition of fish passing through the fish screen facility, and 3 ) possible changes to the screen facllity to reduce identified effects.

\section{PHASE ILI}

Phase III tests are conducted to determine screen operating conditions and canal flow changes that may affect the efficiency of the screens. The test design, test organisms, and most study objectives are the same as those in Phases I and IIa. Study objectives addressed are operational conditions that maximize screen efficiency, effectiveness of the screens over a range of flows, and factors that affect fish transit time through the facilities.

Expected results from these data include 1) determination of any change in the effectiveness of the facility over a range of canal flows, and 2) examination of factors that may change the transit time through the facility. 


\section{PHASE IV}

Phase IV monttoring is conducted to determine if pisctvorous predators are present near the screen factlity and if fish can pass through or over the screen factlity thto the canal.

Phase IV has two parts; both are monttoring studles. Phase IVa is destgned to examine presence and temporal distribution of predators near the screens, and Phase IVb is designed to examine rates of impingement on the screens.

Phase IVa.

Phase IVa includes use of an inclined plane, fyke nets, beach seines, or electroshocker to monitor presence and tempora? distribution of natural fish populations in the area of the facility. Proposed locations for monttoring are downstream of the headworks. in the canal downstream of the factlity, and in the river downstream of the discharge.

The collection equipment are used at predesignated times. Sample duration is determined by consultation with BPA and Yakima Basin fisheries agencies and the priority of the Phase IV work. Phase IVa monttoring at the inclined plane continue during every mark/release test. The presence and quantity of any predators are noted.

Study objectives addressed are the presence of fish populations near the factlity and fish passage through the factitty.

Expected results from these data include 1) a qualitative determination of the fish predator populations in the area of the facility, 2) an evaluation of effectiveness of the screens in keeping fish from entering the canal downstream of the screens, and 3 ) the arrival time at the screen factlity for salmonid populations.

Phase IVb.

Phase IVb monitoring examines the rotating screens and the vertical traveling screens.

If necessary. Phase IVb objectives may be met with a task other than monitoring. For example, marked fish may have to be released in front of the screers, and subsequent monttoring behind the screens will indicate whether or not fish are able enter the canal through or over the screens.

The study objective is to address the rates of impingement on the rotating and traveling screens. 
Expected results from these data Anclude 1) the rate of impingement on the rotating screens, 2) the rate of tmptngement on the traveling screens, and 3 ) the operational conditions that result in increased impingement.

This task will not be necessary if impingement does not occur during operation of the facllity. This is evaluated durting Phase I and II. 


\section{APPENDIX B}

RELEASE AND CAPTURE DATA EROM SUNNYSIDE. RICHLAND. TOPPENISH/SATUS. WAPATO. TOPPENISH CREEK. AND WESTSIDE DITCH CANAL FISH SCREENING FACILIIIES

This appendix contains data collected during 1985 through 1989 at Sunnyside (Neitzel et al. 1985, 1990), Richland (Nettzel et al. 1986, 1988), Toppenish/Satus (Neitzel et a1. 1986). Wapato (Neitzel et al. 1988, 1990) and Toppenish Creek (Neitzel et al. 1990) Canal Fish Screening Facilities. Additionally, the data collected during 1989 at Westside Ditch and Wapato Screens are presented. Data presented in the Results sections are sometimes combined (i.e.. individual trials within a test series were combined for a single estimate). In this appendix we are trying to present the data from each of the individual trials that were conducted. Descaled fish were considered dead for the estimates presented here, as they were in the Results sections of each of the annual reports. Dead and descaled fish were combined to evaluate screen performance.

Data from the Sunnyside Screens (Neitzel et al. 1985) indicate that fish are safely diverted from the canal to the river. Data are presented in Tables B.1 through B.7. The data in Tables B.1 and B.2 represent evaluation of the inclined plane and fyke net. Both samplers collected fish without killing or descaling the fish. Data in Tables B.3 and B.4 are evaluations of the condition of test fish before release in the canal or screen facility. Test fish were in good condition before their release. Data in Tables B.5 and B.6 are the results of the screening factifty evaluations. Descaling data from upriver hatchery and native fish are presented in Table B.7. Data in Table B.45 are the estimated times for test fish to move through the Sunnyside Screen facility. The screen integrity tests indicate that iess than $2 \%$ of test fish pass through or over the screens. The screen integrity data are presented in Tables $B .46$ through B. 48 .

Data from the Richland Screens (Neitzel et a1. 1986, 1988) evaluation indicate that fish are safely diverted from the canal to the river. Data from the 1986 evaluation are presented in Tables B.8 through B.15 and from the 1987 evaluation in Tables B.25 and B.29. Data in Tables B.8 and B.9 are from the evaluation of the inclined plane and the fyke net. The inclined plane safely collected fish. The fyke net descaled too many fish to be used as an effective collection device at the terminus of the Richland Canal fish return pipe during flows of $0.6 \mathrm{~m} 3 / \mathrm{s}$ ( $20 \mathrm{cfs}$ ). Therefore, we used an electroshocker to collect fish during the evaluation of the fish return pipe. Data in Tables B.10 and B.11 are evaluations of the condition of the test fish before their release into the canal. Fish were in good condition before release. Data in Tables B.12 and B.13 are the results of screening facility evaluations. Data in Table B.14 are the estimated times for test fish to move through the Richland Screen Facility. 
Descaling data from upriver hatchery and native fish are presented in Table B.15 (1986 data) and Table B.25 (1987 data). The screen integrlty data collected at Richland Canal in 1987 are presented in Table B.29.

Data from the Toppenish/Satus Screens evaluation indicate that fish are safely diverted from the canal to the river. Data are presented in Tables B.16 through B.19. Data in Table B.16 are evaluations of the condition of the test fish before release in the canal. The fish were in marginal condition before testing. The water temperature at the canal during testing was near $20^{\circ} \mathrm{C}$; therefore we acclimated the test fish to near $20^{\circ} \mathrm{C}$. The scales were loose on the test fish and many of them became descaled during acclimation and transport; however, the test data are useful. The condition of the test fish as a population was not degraded by passage through the screen diversion. This conclusion is based on the change of condition between test and control populations. Data in Table B.17 are the results of screening facility evaluations. Data in Table B.18 are the estimated times for test fish to move through the Toppenish/Satus Screen Facllity. Descaling data from upriver hatchery-released and native fish are presented in Table B.19.

Data from the Wapato Screens evaluation indicate that fish are safely diverted from the canal to the river. The evaluation of the potential for screen passage at wapato indicates that few fish pass through and over the screens: the estimated number based on tests with fall chinook salmon fry is less than 2\%. Data from the tests at the Wapato Screens are presented in Tables B.20 through B.24, B.26 through B.28, and B.30 through B.32. Data in Tables B.20 are from the evaluations of the inclined plane and nets used to capture fish at the Wapato Screens. The plane and nets safely collected fish. Data in Table B.21 and B.22 are evaluations of the condition of the test fish before release in the canal. Fish were in good condition before release. Data in Tables B.23 and B.24 are the results of the screening facility evaluations. Table B.26 presents the descaling data collected from upriver native and hatchery salmonids captured during the evaluation tests. Tables B.2.7 and B.51 presents data from a test of the fish return pipe at the Wapato Screens. Tables B.28, B.32, and B.41 give data used to estimate the migration time through the screen facility for test fish. Tables B.30, B.31, B.42, B.43, and B.44 give the data from the screen integrity tests at the Wapato Screens.

Data from the Toppenish Creek Screens indicate that fish are safely diverted from the canal to the river. Data are presented in Tables B.33 through B.40. The data in Table B.33 represent evaluation of the inclined plare. The plane collected fish without killing or descaling the fish. Data in Table B.34 are evaluations of the condition of test fish before release in the canal or screen facllity. Test fish were in good condition before their release. The data for the descaling evaluations are in Tables B.35 and B.38. Data in Table B.36 are the estimated times for test fish to move through the Toppenish Creek Screen Factlity. Data in Table B.39 and 40 are the results of the screen integrity evaluations. The screen 
integrity tests indicate that less than $1 \%$ of test fish pass through or over the screens.

Data from Westside Ditch indicate that fish are not descaled at the screen facility. Zero-age chinook salmon can pass through, over or around the screens. Data are presented in Tables B.49, B.50 and B.52 through B. 54 . The data for the descaling evaluations are in Table B.49. Data in Table B.50 are the estimated times for test fish to move through Westside Diich. Data in Table B.52 through B.54 are the results of the screen integrity evaluations. 
IABLE B.1. Percentage of Coho Salmon Oncorhynchus kisutch Smolts Descaled or Killed During Tests of the Inclined Plane at Sunnyside Canal Fish Screening Facility. Spring 1985

\begin{tabular}{|c|c|c|c|c|c|}
\hline \multirow[b]{2}{*}{$\begin{array}{c}\text { TEST } \\
\text { REPLICATE } \\
\end{array}$} & \multicolumn{3}{|c|}{ NUMBER OF FISH } & \multirow{2}{*}{$\begin{array}{c}\text { PERCENT } \\
\text { DESCALED OR } \\
\text { KILLED }\end{array}$} & \multirow{2}{*}{$\begin{array}{c}95 \% \\
\text { CONFIDENCE } \\
\text { INTERVAL }\end{array}$} \\
\hline & $\begin{array}{l}\text { PLACED ON } \\
\text { PLANE }\end{array}$ & CAPTURED & $\begin{array}{c}\text { DESCALED OR } \\
\text { KILLED }\end{array}$ & & \\
\hline 1 & 10 & 7 & 0 & 0 & $0-41.0$ \\
\hline 2 & 10 & 9 & 0 & 0 & $0-33.6$ \\
\hline 3 & 10 & 10 & 0 & 0 & $0-30.8$ \\
\hline 4 & 10 & 10 & 0 & 0 & $0-30.8$ \\
\hline 5 & 10 & 10 & 0 & 0 & $0-30.8$ \\
\hline 6 & 10 & 8 & 0 & 0 & $0-37.0$ \\
\hline 7 & 10 & 10 & 0 & 0 & $0-30.8$ \\
\hline 8 & 10 & 10 & 0 & 0 & $0-4.8$ \\
\hline TOTAL & 80 & 74 & 0 & 0 & $0-4.8$ \\
\hline
\end{tabular}

TABLE B.2. Percentage of Steelhead Oncorhynchus mykiss and Chinook Salmon 0 . tshawytscha Smolts Descaled or Killed During Tests of the Fyke Net at Sunnyside Canal Fish Screening Facility. Spring 1985

\begin{tabular}{|c|c|c|c|c|c|}
\hline SPECIES \& & & MBER OF $F$ & & PERCENT & $95 \%$ \\
\hline $\begin{array}{c}\text { TEST } \\
\text { REPLICATE }\end{array}$ & $\begin{array}{l}\text { PLACED ON } \\
\text { PLANE }\end{array}$ & CAPTURED & $\begin{array}{c}\text { DESCALED OR } \\
\text { KILLED }\end{array}$ & $\begin{array}{c}\text { DESCALED OR } \\
\text { KILLED }\end{array}$ & $\begin{array}{l}\text { CONFIDENCE } \\
\text { INTERVAL }\end{array}$ \\
\hline Steelhead 1 & 50 & 8 & 0 & 0 & $0-36.0$ \\
\hline Steelhead 2 & 50 & 28 & 0 & 0 & $0-12.3$ \\
\hline Steel head 3 & 55 & 21 & 0 & 0 & $0-16.1$ \\
\hline TOTAL & 155 & 57 & 0 & 0 & $0-6.3$ \\
\hline $\begin{array}{l}\text { Chinook } \\
\text { Salmon } 1 \\
\end{array}$ & 50 & 21 & 0 & 0 & $0-16.1$ \\
\hline
\end{tabular}


IABLE B.3. Percentage of Steelhead Oncorhynchus mykiss Smolts Descaled Before Being Used in Tests at Sunnyside Canal Fish Screening Facility, Spring 1985

\begin{tabular}{|c|c|c|c|c|}
\hline $\begin{array}{l}\text { TEST } \\
\text { SITE } \\
\end{array}$ & $\begin{array}{r}\text { NUMBE } \\
\text { EVALUATED } \\
\end{array}$ & $\begin{array}{l}\text { FISH } \\
\text { DESCALED }\end{array}$ & $\begin{array}{l}\text { PERCENT } \\
\text { DESCALED }\end{array}$ & $\begin{array}{c}95 \% \\
\text { CONFIDENCE } \\
\text { INTERVAL }\end{array}$ \\
\hline $\begin{array}{c}\text { Intermediate } \\
\text { Bypass }\end{array}$ & 24 & 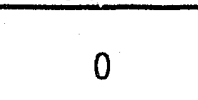 & 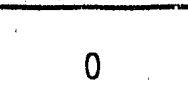 & $0-14.3$ \\
\hline $\begin{array}{c}\text { Terminal } \\
\text { Bypass }\end{array}$ & 13 & 0 & 0 & $0-24.7$ \\
\hline $\begin{array}{l}\text { Trash } \\
\text { Rack }\end{array}$ & 19 & 0 & 0 & $0-17.7$ \\
\hline $\begin{array}{c}\text { Canal Head } \\
\text { Gates }\end{array}$ & 20 & 0 & 0 & $0-16.8$ \\
\hline
\end{tabular}

IABLE B.4. Percentage of Chinook Salmon Oncorhynchus tshawytscha Smolts Descaled Before Being Used in Tests at Sunnyside Canal Fish Screening Facility. Spring 1985

\begin{tabular}{|c|c|c|c|c|}
\hline $\begin{array}{l}\text { TEST } \\
\text { SITE }\end{array}$ & $\frac{\text { NUMB: }}{\text { EVALUATED }}$ & $\frac{\text { FISH }}{\text { DESCALED }}$ & $\begin{array}{l}\text { PERCENT } \\
\text { DESCALED }\end{array}$ & $\begin{array}{c}95 \% \\
\text { CONFIDENCE } \\
\text { INTERVAL }\end{array}$ \\
\hline $\begin{array}{l}\text { Primary Fish } \\
\text { Return Pipe }\end{array}$ & 36 & 0 & 0 & $0-9.7$ \\
\hline $\begin{array}{c}\text { Intermediate } \\
\text { Bypass }\end{array}$ & 20 & 0 & 0 & $0-16.8$ \\
\hline $\begin{array}{c}\text { Terminal } \\
\text { Bypass }\end{array}$ & 20 & 0 & 0 & $0-16.8$ \\
\hline $\begin{array}{l}\text { Trash } \\
\text { Rack }\end{array}$ & 20 & 0 & 0 & $0-16.8$ \\
\hline $\begin{array}{c}\text { Canal Head } \\
\text { Gates }\end{array}$ & 32 & 0 & 0 & $0-9.7$ \\
\hline
\end{tabular}


IABLE B.5. Percentage of Steelhead Oncorhynchus mykiss Smolts Descaled or killed in Each Test at Sunnyside Canal Fish Screening Facility, Spring 1985

\begin{tabular}{|c|c|c|c|c|c|c|}
\hline \multirow[b]{2}{*}{$\begin{array}{l}\text { RELEASE } \\
\text { SITE }\end{array}$} & \multirow[b]{2}{*}{$\begin{array}{c}\text { TEST } \\
\text { REPLICATE } \\
\end{array}$} & \multicolumn{3}{|c|}{ NUMBER OF FISH } & \multirow{2}{*}{$\begin{array}{l}\text { PERCENT } \\
\text { DESCALED } \\
\text { OR KILLED }\end{array}$} & \multirow{2}{*}{$\begin{array}{c}95 \% \\
\text { CONFIDENCE } \\
\text { INTERVAL }\end{array}$} \\
\hline & & RELEASED & CAPTURED & $\begin{array}{l}\text { DESCALED } \\
\text { OR KILLED }\end{array}$ & & \\
\hline $\begin{array}{l}\text { Primary Fish } \\
\text { Return Pipe }\end{array}$ & 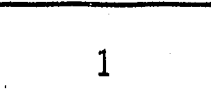 & 50 & 8 & 0 & 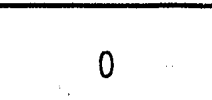 & $0-36.8$ \\
\hline & 2 & 50 & 16 & 0 & 0 & $0-20.6$ \\
\hline & 3 & 72 & 6 & 0 & 0 & $0-45.9$ \\
\hline $\begin{array}{l}\text { Intermediate } \\
\text { Bypass }\end{array}$ & 1 & 275 & 139 & 0 & 0 & $0-2.6$ \\
\hline $\begin{array}{l}\text { Terminal } \\
\text { Bypass }\end{array}$ & 1 & 200 & 112 & 0 & 0 & $0-3.2$ \\
\hline Trash Rack & 1 & 500 & 126 & 0 & 0 & $0-2.9$ \\
\hline $\begin{array}{l}\text { Canal Head } \\
\text { Gates }\end{array}$ & 1 & 500 & 100 & 0 & 0 & $0-3.6$ \\
\hline
\end{tabular}


IABLE B.6. Percentage of Chinook Salmon Oncorhynchus tshawytscha Smolts Descaled or Killed in Each Test at Sunnyside Canal Fish Screening Facility. Spring 1985

\begin{tabular}{|c|c|c|c|c|c|c|}
\hline \multirow[b]{2}{*}{$\begin{array}{l}\text { RELEASE } \\
\text { SITE }\end{array}$} & \multirow[b]{2}{*}{$\begin{array}{c}\text { TEST } \\
\text { REPLICATE }\end{array}$} & \multicolumn{3}{|c|}{ NUMBER OF FISH } & \multirow{2}{*}{$\begin{array}{l}\text { PERCENT } \\
\text { DESCALED } \\
\text { OR KILLED }\end{array}$} & \multirow{2}{*}{$\begin{array}{c}95 \% \\
\text { CONFIDENCE } \\
\text { INTERVAL }\end{array}$} \\
\hline & & RELEASED & CAPTURED & $\begin{array}{l}\text { DESCALED } \\
\text { OR KILLED }\end{array}$ & & \\
\hline \multirow[t]{5}{*}{$\begin{array}{l}\text { Primary Fish } \\
\text { Return Pipe }\end{array}$} & 1 & 100 & 83 & 0 & 0 & $0.0-4.4$ \\
\hline & 2 & 100 & 64 & 2 & 3.1 & $0.4-10.8$ \\
\hline & 3 & 100 & 75 & 0 & 0 & $0.0-4.8$ \\
\hline & 4 & 100 & 60 & 1 & 1.7 & $0.0-8.9$ \\
\hline & 5 & 100 & 89 & 0 & 0 & $0.0-4.1$ \\
\hline \multirow[t]{5}{*}{$\begin{array}{l}\text { Intermediate } \\
\text { Bypass }\end{array}$} & 1 & 100 & 82 & 2 & 2.4 & $0.3-8.5$ \\
\hline & 2 & 100 & 95 & 0 & 0 & $0.0-3.8$ \\
\hline & 3 & 100 & 99 & 0 & 0 & $0.0-3.7$ \\
\hline & 4 & 100 & 95 & 2 & 2.1 & $0.3-7.4$ \\
\hline & 5 & 100 & 97 & 0 & 0 & $0.0-3.7$ \\
\hline \multirow[t]{5}{*}{$\begin{array}{l}\text { Terminal } \\
\text { Bypass }\end{array}$} & 1 & 100 & 98 & 2 & 2 & $0.3-7.2$ \\
\hline & 2 & 100 & 96 & 1 & 1 & $0.0-5.7$ \\
\hline & 3 & 100 & 98 & 0 & 0 & $0.0-3.7$ \\
\hline & 4 & 100 & 98 & 3 & 3.1 & $0.6-8.7$ \\
\hline & 5 & 92 & 86 & 1 & 1.2 & $0.0-6.3$ \\
\hline Trash Rack & 1 & 1000 & 856 & 20 & 2.3 & $1.4-3.6$ \\
\hline \multirow[t]{2}{*}{$\begin{array}{l}\text { Canal Head } \\
\text { Gates }\end{array}$} & 1 & 1000 & 729 & 6 & 0.8 & $0.2-1.6$ \\
\hline & 2 & 1000 & 725 & 21 & 2.9 & $2.0-4.7$ \\
\hline
\end{tabular}


IABLE B.7. Scale Loss for Hatchery-Released and Native Fish Captured During Tests at Sumnside Canal Fish Screening Facility. Spring 1985

\begin{tabular}{|c|c|c|c|c|}
\hline SPECIES & CAPTURED & $\begin{array}{l}\text { FISH } \\
\text { DESCALED } \\
\text { OR KILLED }\end{array}$ & $\begin{array}{l}\text { PERCENT } \\
\text { DESCALED } \\
\text { OR KILLED }\end{array}$ & $\begin{array}{c}95 \% \\
\text { CONFIDENCE } \\
\text { INTERVAL }\end{array}$ \\
\hline $\begin{array}{l}\text { Chinook } \\
\text { Salmon }\end{array}$ & 214 & 9 & 4.2 & $2.0-7.7$ \\
\hline Steelhead & 36 & 1 & 2.8 & $0.2-14.7$ \\
\hline
\end{tabular}

IABLE B.8. Percentage of Chinook Salmon Oncorhynchus tshawytscha Smolts Descaled or Killed During Tests of the Inclined Plane at Richland Canal Fish Screening Facility. Spring 1986

\begin{tabular}{|c|c|c|c|c|c|c|}
\hline \multirow[b]{2}{*}{ SPECIES } & \multirow[b]{2}{*}{$\begin{array}{l}\text { TEST } \\
\text { REP. }\end{array}$} & \multicolumn{3}{|c|}{ NUMBER OF FISH } & \multirow{2}{*}{$\begin{array}{l}\text { PERCENT } \\
\text { DESCALED } \\
\text { OR KILLED }\end{array}$} & \multirow{2}{*}{$\begin{array}{c}95 \% \\
\text { CONFIDENCE } \\
\text { INTERVAL }\end{array}$} \\
\hline & & RELEASED & CAPTURED & $\begin{array}{l}\text { DESCALED } \\
\text { OR KILLED }\end{array}$ & & \\
\hline \multirow[t]{2}{*}{ Spring } & 1 & 25 & 21 & 0 & 0 & $0-16.1$ \\
\hline & Control & & 19 & 0 & 0 & $0-17.7$ \\
\hline \multirow[t]{3}{*}{$\mathrm{Fall}$} & 1 & 25 & 16 & 0 & 0 & $0-20.6$ \\
\hline & Control & & 20 & 0 & 0 & 0.16 .8 \\
\hline & 2 & 500 & 156 & 0 & 0 & 0.2 .3 \\
\hline
\end{tabular}

IABLE B.2. Percentage of Chinook Salmon Oncorhynchus tshawytscha Smolts Descaled or Killed During Tests of the Fyke Net at Richland Canal Fish Screening Facility. Spring 1986

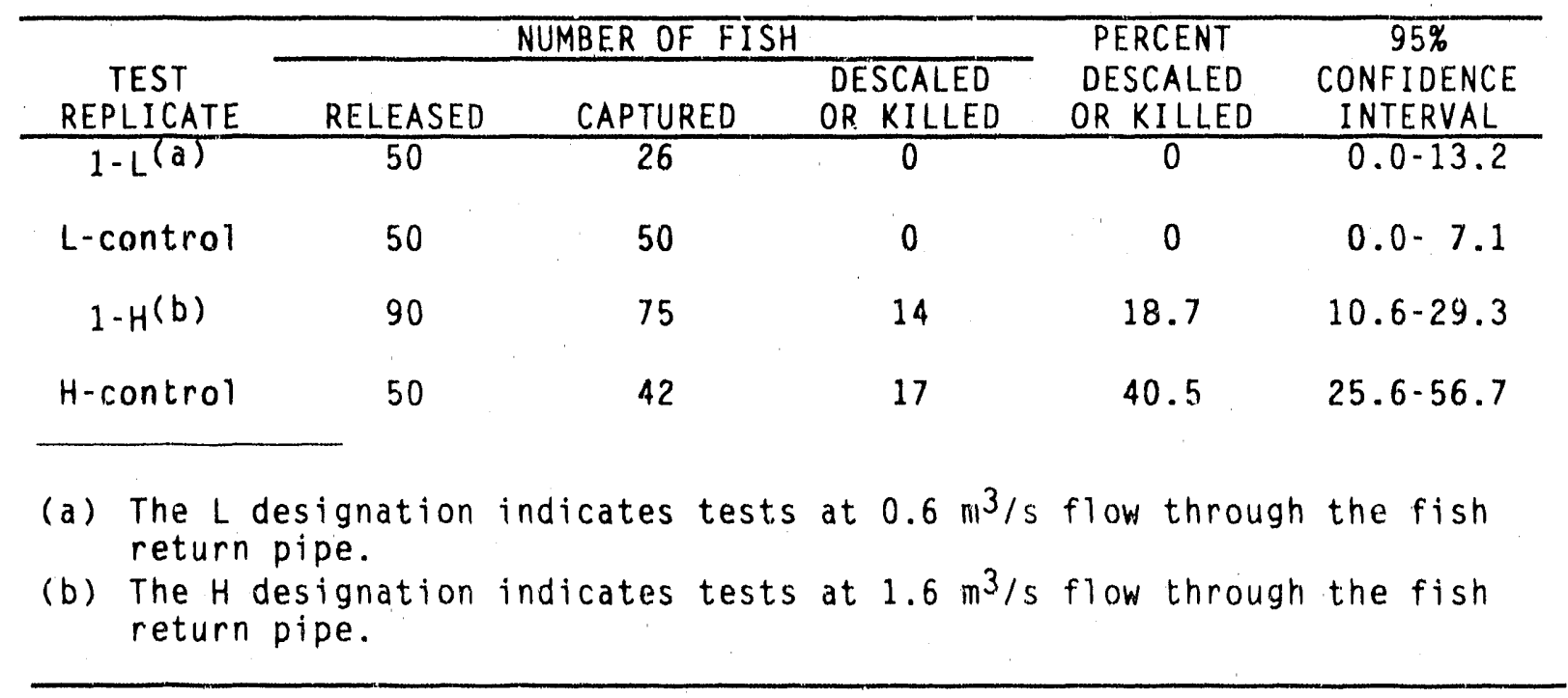


IABLE B.10. Percentage of Steelhead Oncorhynchus mykiss Smolts Descaled Before Being Used in Tests at Richland Canal Fish Screening Facility. Spring 1986

\begin{tabular}{|c|c|c|c|c|c|}
\hline \multirow[b]{2}{*}{$\begin{array}{c}\text { TEST } \\
\text { REPLICATE }\end{array}$} & \multicolumn{3}{|c|}{ NUMBER OF FISH } & \multirow{2}{*}{$\begin{array}{l}\text { PERCENT } \\
\text { DESCALED } \\
\text { OR KILLED }\end{array}$} & \multirow{2}{*}{$\begin{array}{c}95 \% \\
\text { CONFIDENCE } \\
\text { INTERVAL }\end{array}$} \\
\hline & RELEASED & CAPTURED & $\begin{array}{l}\text { DESCALED } \\
\text { OR KILLED }\end{array}$ & & \\
\hline 1 & 100 & 100 & 0 & 0 & $0-3.6$ \\
\hline 2 & 100 & 100 & 0 & 0 & $0-3.6$ \\
\hline 3 & 101 & 101 & 1 & 1 & $0-5.4$ \\
\hline TOTAL & 301 & 301 & 1 & 0.3 & $0-1.8$ \\
\hline
\end{tabular}

IABLE B.11. Percentage of Chinook Salmon Oncorhynchus tshawytscha Smolts Descaled Before Being Used in Tests at Richland Canal Fish Screening Facility. Spring 1986

\begin{tabular}{|c|c|c|c|c|c|}
\hline \multirow[b]{2}{*}{$\begin{array}{c}\text { TEST } \\
\text { REPLICATE }\end{array}$} & \multicolumn{3}{|c|}{ NUMBER OF FISH } & \multirow{2}{*}{$\begin{array}{l}\text { PERCENT } \\
\text { DESCALED } \\
\text { OR KILLED }\end{array}$} & \multirow{2}{*}{$\begin{array}{c}95 \% \\
\text { CONFIDENCE } \\
\text { INTERVAL }\end{array}$} \\
\hline & RELEASED & CAPTURED & $\begin{array}{l}\text { DESCALED } \\
\text { OR KILLED }\end{array}$ & & \\
\hline 1 & 100 & 100 & 0 & 0 & $0-3.6$ \\
\hline 2 & 100 & 100 & 0 & 0 & $0-3.6$ \\
\hline 3 & 102 & 102 & 0 & 0 & $0-3.6$ \\
\hline TOTAL & 302 & 302 & 0 & 0 & $0-1.2$ \\
\hline
\end{tabular}

TABLE B.12. Descaling and Mortality Data from Release and Capture Tests with Steelhead Oncorhynchus mykiss Smolts at Richland Canal Fish Screening Facility. Spring 1986

\begin{tabular}{|c|c|c|c|c|c|}
\hline \multirow[b]{2}{*}{$\begin{array}{c}\text { TEST } \\
\text { REPLICATE }\end{array}$} & \multicolumn{3}{|c|}{ NUMBER OF FISH } & \multirow{2}{*}{$\begin{array}{l}\text { PERCENT } \\
\text { DESCALED } \\
\text { OR KILLED }\end{array}$} & \multirow{2}{*}{$\begin{array}{c}95 \% \\
\text { CONFIDENCE } \\
\text { INTERVAL }\end{array}$} \\
\hline & RELEASED & CAPTURED & $\begin{array}{l}\text { DESCALED } \\
\text { OR KILLED }\end{array}$ & & \\
\hline 1 & 200 & 129 & 1 & 0.8 & $0.2-4.2$ \\
\hline 2 & 200 & 132 & 2 & 1.5 & $0.2-5.4$ \\
\hline 3 & 200 & 102 & 1 & 1.1 & $0.3-2.8$ \\
\hline TOTAL & 600 & 363 & 4 & 1.1 & $0.3-2.8$ \\
\hline
\end{tabular}




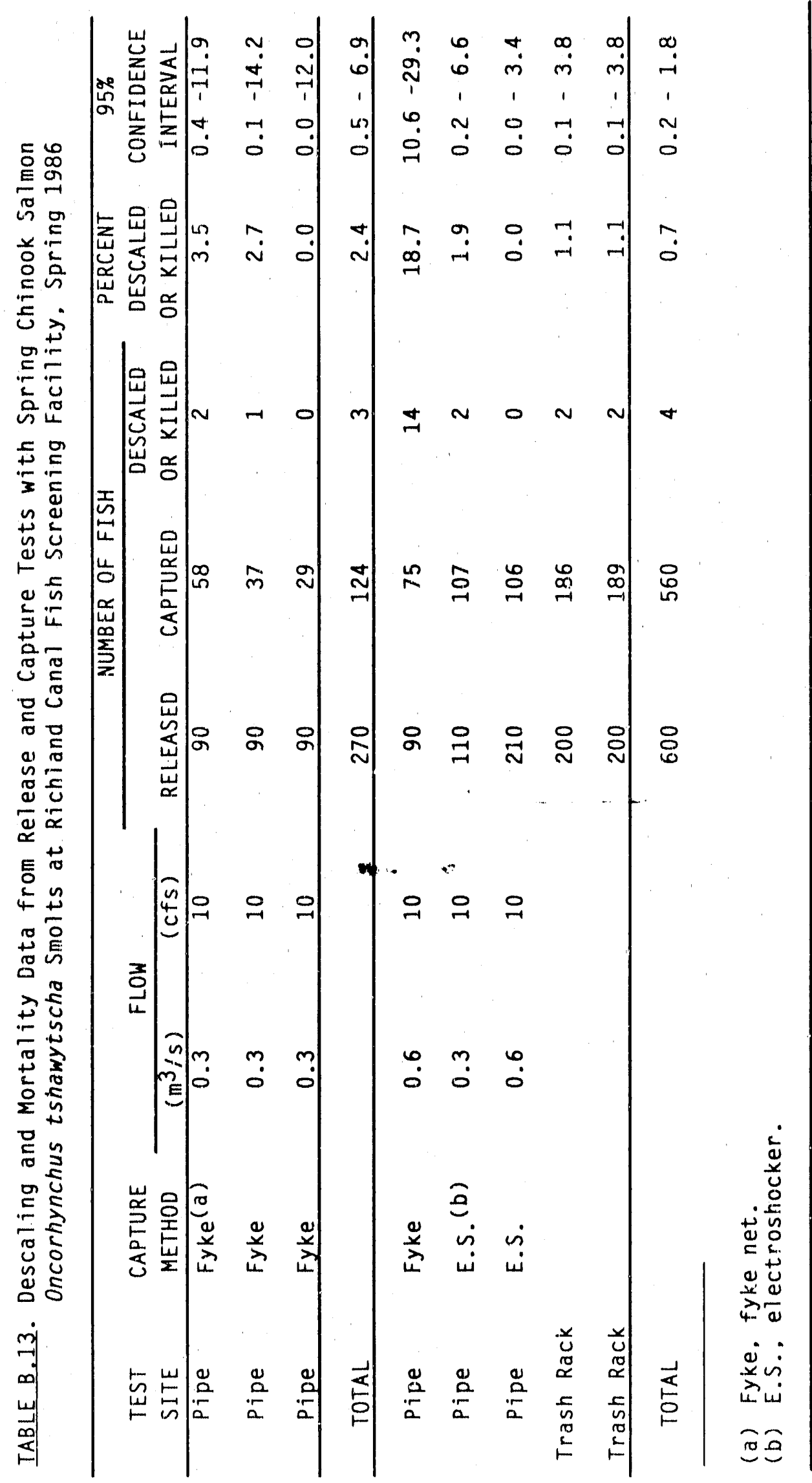


IABLE B.14. Estimated Time ( $h$ ) to Catch $50 \%$ and $95 \%$ of Test Fish Captured at Richland Canal Fish Screening Facllity. Spring 1986

\begin{tabular}{|c|c|c|c|c|c|c|}
\hline \multirow[b]{2}{*}{ SPECIES } & \multicolumn{3}{|c|}{ TIME TO CATCH } & \multicolumn{2}{|c|}{ NUMBER OF FISH } & \multirow{2}{*}{$\begin{array}{l}\text { PERCENT } \\
\text { CAPTURED }\end{array}$} \\
\hline & GROUP & $50 \%$ & $90 \%$ & RELEASED & CAPTURED & \\
\hline Steelhead & 1 & 18.0 & 52.5 & 200 & 129 & 64.5 \\
\hline Steelhead & 2 & 21.0 & 48.0 & 200 & 134 & 67.0 \\
\hline Steelhead & 3 & 29.0 & 54.5 & 200 & 102 & 51.0 \\
\hline $\begin{array}{l}\text { Spring } \\
\text { Chinook }\end{array}$ & 1 & 0.5 & 6.5 & 200 & 186 & 93.0 \\
\hline $\begin{array}{l}\text { Spring } \\
\text { Chinook }\end{array}$ & 2 & 1.0 & 5.0 & 200 & 188 & 94.0 \\
\hline $\begin{array}{l}\text { Spring } \\
\text { Chinook }\end{array}$ & 3 & 1.0 & 3.5 & 200 & 185 & 92.5 \\
\hline $\begin{array}{c}\text { Fall } \\
\text { Chinook }\end{array}$ & 1 & 9.5 & 34.5 & 1000 & 638 & 63.8 \\
\hline $\begin{array}{c}\text { Fal1 } \\
\text { Chinook }\end{array}$ & 2 & 8.5 & 32.0 & 1150 & 682 & 59.3 \\
\hline $\begin{array}{c}\text { Fal1 } \\
\text { Chinook }\end{array}$ & 3 & 7.0 & 31.0 & 1150 & 809 & 70.3 \\
\hline
\end{tabular}

IABLE B. 15. Scale Loss for Hatchery-Released and Native Fish Captured During Tests at Richland Canal Fish Screening Facility. Spring 1986

\begin{tabular}{|c|c|c|c|c|}
\hline & \multicolumn{2}{|c|}{ NUMBER OF FISH } & \multirow{2}{*}{$\begin{array}{c}\text { PERCENT } \\
\text { DESCALED } \\
\text { OR KILLED }\end{array}$} & \multirow{2}{*}{$\begin{array}{c}95 \% \\
\text { CONFIDENCE } \\
\text { INTERVAL } \\
\end{array}$} \\
\hline SPECIES & CAPTURED & $\begin{array}{l}\text { DESCALED } \\
\text { OR KILLED }\end{array}$ & & \\
\hline $\begin{array}{l}\text { Chinook } \\
\text { Salmon (a) }\end{array}$ & 64 & 3 & 4.7 & $1.0-11.0$ \\
\hline Coho Salmon & 17 & 3 & 17.7 & $3.8-48.0$ \\
\hline Steelhead & 51 & 3 & 5.9 & $1.3-18.9$ \\
\hline $\begin{array}{l}\text { (a) Primarti } \\
\text { fall chi } \\
\end{array}$ & $\begin{array}{l}\text { spring chinook } \\
\text { ok salmon }(<10\end{array}$ & $\begin{array}{l}\text { salmon }(>10 \mathrm{~cm} \\
\mathrm{cm} F L) .\end{array}$ & $F($ ) but including & some \\
\hline
\end{tabular}


IABLE B.16. Percentage of Steelhead Oncorhynchus mykiss Smolts Descaled Before Being Used in Tests at Toppentsh/Satus Canal Fish Screenting Factlity, Spring 1986

\begin{tabular}{|c|c|c|c|c|c|}
\hline \multirow[b]{2}{*}{$\begin{array}{c}\text { TEST } \\
\text { REPLICATE } \\
\end{array}$} & \multicolumn{3}{|c|}{ NUMBER OF FISH } & \multirow{2}{*}{$\begin{array}{l}\text { PERCENT } \\
\text { DESCALED } \\
\text { OR KILLED } \\
\end{array}$} & \multirow{2}{*}{$\begin{array}{c}95 \% \\
\text { CONFIDENCE } \\
\text { INTERVAL }\end{array}$} \\
\hline & RELEASED & CAPTURED & $\begin{array}{l}\text { DESCALED } \\
\text { OR KILLED }\end{array}$ & & \\
\hline 1 & 103 & 103 & 37 & 35.9 & $26.7-46.0$ \\
\hline 2 & 103 & 103 & 29 & 28.2 & $19.7-37.9$ \\
\hline 3 & 105 & 105 & 16 & 15.2 & $22.0-32.9$ \\
\hline TOTAL & 311 & 311 & 82 & 26.4 & $22.0-32.9$ \\
\hline
\end{tabular}

IABLE B.17. Descaling and Mortaltty Data from Release and Capture Tests with Steelhead Oncorhynchus mykiss Smolts at Toppenish/Satus Canal Fish Screening Facility. Spring 1986

\begin{tabular}{cccccc}
\hline & \multicolumn{3}{c}{ NUMBER OF FISH } & PERCENT & $\begin{array}{c}\text { 95\% } \\
\text { TEST }\end{array}$ \\
\cline { 2 - 6 } REPLICATE & RELEASED & CAPTURED & OR KCALED & DESCALED & CONFIDENCE \\
\hline 1 & 520 & 462 & 120 & 26.0 & $23.1-31.3$ \\
2 & 520 & 463 & 102 & 22.0 & $19.4-27.1$ \\
3 & 520 & 463 & 40 & 8.6 & $0.2-11.6$ \\
\hline TOTAL & 1560 & 1388 & 262 & 18.9 & $17.4-21.6$ \\
\hline
\end{tabular}


TABLE B.18. Estimated Time $(h)$ to Catch $50 \%$ and $95 \%$ of Test Fish Captured at Toppenish/Satus Carlal Fish Screening Facllity. Spring 1986

\begin{tabular}{|c|c|c|c|c|c|c|}
\hline \multirow[b]{2}{*}{ SPECIES } & \multicolumn{3}{|c|}{ TIME TO CATCH (h) } & \multicolumn{2}{|c|}{ NUMBER OF FISH } & \multirow{2}{*}{$\begin{array}{l}\text { PERCENT } \\
\text { CAPTURED }\end{array}$} \\
\hline & GROUP & $50 \%$ & $95 \%$ & RELEASED & CAPTURED & \\
\hline Steelhead & 1 & 12.5 & 41 & 520 & 462 & 88.8 \\
\hline Steel head & 2 & 12 & 46.5 & 520 & 464 & 89.2 \\
\hline Steelhead & 3 & 10 & 42.5 & 520 & 463 & 89.0 \\
\hline $\begin{array}{l}\text { Spring } \\
\text { Chinook }\end{array}$ & 1 & 0.5 & 1.5 & 360 & 356 & 98.9 \\
\hline $\begin{array}{l}\text { Spring } \\
\text { Chinook }\end{array}$ & 2 & 0.5 & 1.5 & 335 & 329 & 98.2 \\
\hline $\begin{array}{l}\text { Spring } \\
\text { Chinook }\end{array}$ & 3 & 0.5 & 1.5 & 335 & 314 & 93.7 \\
\hline $\begin{array}{l}\text { Fall } \\
\text { Chinook }\end{array}$ & 1 & 0.5 & 0.5 & 1000 & 728 & 72.8 \\
\hline $\begin{array}{l}\text { Fall } \\
\text { Chinook }\end{array}$ & 2 & 0.5 & 0.5 & 1000 & 702 & 70.2 \\
\hline $\begin{array}{l}\text { Fal1 } \\
\text { Chinook }\end{array}$ & 3 & 0.5 & 0.5 & 460 & 330 & 71.7 \\
\hline
\end{tabular}

IABLE B.19. Scale Loss for Hatchery-Released and Native Fish Captured During Tests at Toppenish/Satus Canal Fish Screening Facility. Spring 1986

\begin{tabular}{lcccc}
\hline & NUMBER OF FISH & PERCENT & 95\% \\
\cline { 2 - 5 } SPECIES & CAPTURED & $\begin{array}{c}\text { DESCALED } \\
\text { OR KILLED }\end{array}$ & $\begin{array}{c}\text { DESCALED } \\
\text { OR KILLED }\end{array}$ & $\begin{array}{c}\text { CONFIDENCE } \\
\text { INTERVAL }\end{array}$ \\
\hline Steelhead (1-age) & 20 & 0 & 0 & $0.0-16.8$ \\
Steelhead (0-age) & 69 & 0 & 0 & $0.0-05.2$ \\
Coho Salmon (1-age) & 29 & 0 & 0 & $0.0-12.0$ \\
Chinook Salmon & 25 & 1 & 4 & $0.1-20.4$ \\
\hline
\end{tabular}


IABLE B.20. Percentage of Spring Chtnook Salmon Oncorhynchus tshawytscha and Steelhead Oncorhynchus mykiss Smolts Descaled or Killed During Tests of the Inclined Plane at Wapato Canal Fish

Screening Factlity, Spring 1987

\begin{tabular}{|c|c|c|c|c|c|}
\hline SPECIES & \multicolumn{2}{|c|}{ NUMBER OF FISH } & \multicolumn{2}{|r|}{ PERCENT } & $\begin{array}{c}95 \% \\
\text { CONFIDENCE } \\
\text { INTERVAL }\end{array}$ \\
\hline Steelhead & 10 & 9 & 0 & 0 & 0.33 .6 \\
\hline Steel head & 10 & 9 & 0 & 0 & $0-33.6$ \\
\hline TOTAL & 20 & 18 & 0 & 0 & 0.17 .7 \\
\hline $\begin{array}{l}\text { Spring } \\
\text { Chinook }\end{array}$ & 10 & 10 & 0 & 0 & 0.30 .8 \\
\hline $\begin{array}{c}\text { Spring } \\
\text { Chinook }\end{array}$ & 10 & 10 & 0 & 0 & $0-30.8$ \\
\hline TOTAL & 20 & 20 & 0 & 0 & $0-16.8$ \\
\hline$I A B \perp E B .21$. & $\begin{array}{l}\text { Percentage } \\
\text { Before Bei } \\
\text { Facility. }\end{array}$ & $\begin{array}{l}\text { Steelhead } \\
\text { Used in Te } \\
\text { ing } 1987\end{array}$ & $\begin{array}{l}\text { ncorhynchus } \\
\text { at Wapato }\end{array}$ & $\begin{array}{l}\text { nykiss Smo } \\
\text { ianal Fish }\end{array}$ & $\begin{array}{l}\text { s Descaled } \\
\text { creening }\end{array}$ \\
\hline & CANAL & & & & $95 \%$ \\
\hline TEST & FLOW & NUMBEF & F FISH & PERCENT & CONFIDENCE \\
\hline$\frac{\text { REPLICATE }}{1}$ & $\frac{(C F S)}{800}$ & $\frac{\text { EXAMINED }}{65}$ & $\frac{\text { DESCALED }}{0}$ & $\frac{\text { DESCALED }}{0}$ & $\frac{\text { INTERVAL }}{0.5 .5}$ \\
\hline 2 & 800 & 67 & 1 & 1.5 & $0.0-8.0$ \\
\hline 3 & 800 & 68 & 0 & 0 & 0.5 .3 \\
\hline TOTAL & & 200 & 1 & 0.5 & $0.0-2.8$ \\
\hline 1 & 2000 & 35 & 0 & 0 & $0-10.0$ \\
\hline 2 & 2000 & 32 & 0 & 0 & 0.10 .9 \\
\hline 3 & 2000 & 33 & 0 & 0 & 0.10 .6 \\
\hline TOTAL & & 100 & 0 & 0 & $0-3.6$ \\
\hline 1 & 2000 & 38 & 0 & 0 & $0-9.3$ \\
\hline 2 & 2000 & 36 & 0 & 0 & 0.9 .7 \\
\hline 3 & 2000 & 26 & 0 & 0 & $0-13.2$ \\
\hline TOTAL & & 100 & 0 & 0 & 0.3 .6 \\
\hline TOTAL & & 400 & 1 & 0.3 & $0.0-1.4$ \\
\hline
\end{tabular}


IABLE B.22. Percentage of Spring Chinook Salmon Oncorhynchus tshawytischa Smolts That Were Descaled Before Being Used in Tests at Wapato Canal Fish Screening Facilities, Spring 1987

\begin{tabular}{|c|c|c|c|c|c|}
\hline $\begin{array}{c}\text { TEST } \\
\text { RFPI }\end{array}$ & $\begin{array}{l}\text { CANAL } \\
\text { FLOW } \\
\text { (CfS) }\end{array}$ & $\begin{array}{c}\text { NUMBEF } \\
\text { FXAMINFD }\end{array}$ & $\frac{F \text { FISH }}{D F S C A I F D}$ & $\begin{array}{l}\text { PERCENT } \\
\text { DFSCAIFD }\end{array}$ & $\begin{array}{c}95 \% \\
\text { CONFIDENCE }\end{array}$ \\
\hline 1 & 800 & 74 & 0 & 0 & 0.4 .86 \\
\hline 2 & 800 & 59 & 0 & 0 & 0.6 .06 \\
\hline 3 & 800 & 67 & 0 & 0 & 0.5 .36 \\
\hline TOTAL & & 200 & 0 & 0 & $0-1.83$ \\
\hline 1 & 2000 & 35 & 0 & 0 & 0.10 .00 \\
\hline 2 & 2000 & 35 & 0 & 0 & 0.10 .00 \\
\hline 3 & 2000 & 30 & 0 & 0 & 0.11 .57 \\
\hline TOTAL. & & 100 & 0 & 0 & 0.3 .62 \\
\hline 1 & 2000 & 33 & 0 & 0 & 0.10 .58 \\
\hline 2 & 2000 & 28 & 0 & 0 & $0-12.34$ \\
\hline 3 & 2000 & 39 & 0 & 0 & $0-9.03$ \\
\hline TOTAL & & 100 & 0 & 0 & $0-3.62$ \\
\hline TOTAL & & 400 & 0 & 0 & $0-0.92$ \\
\hline
\end{tabular}




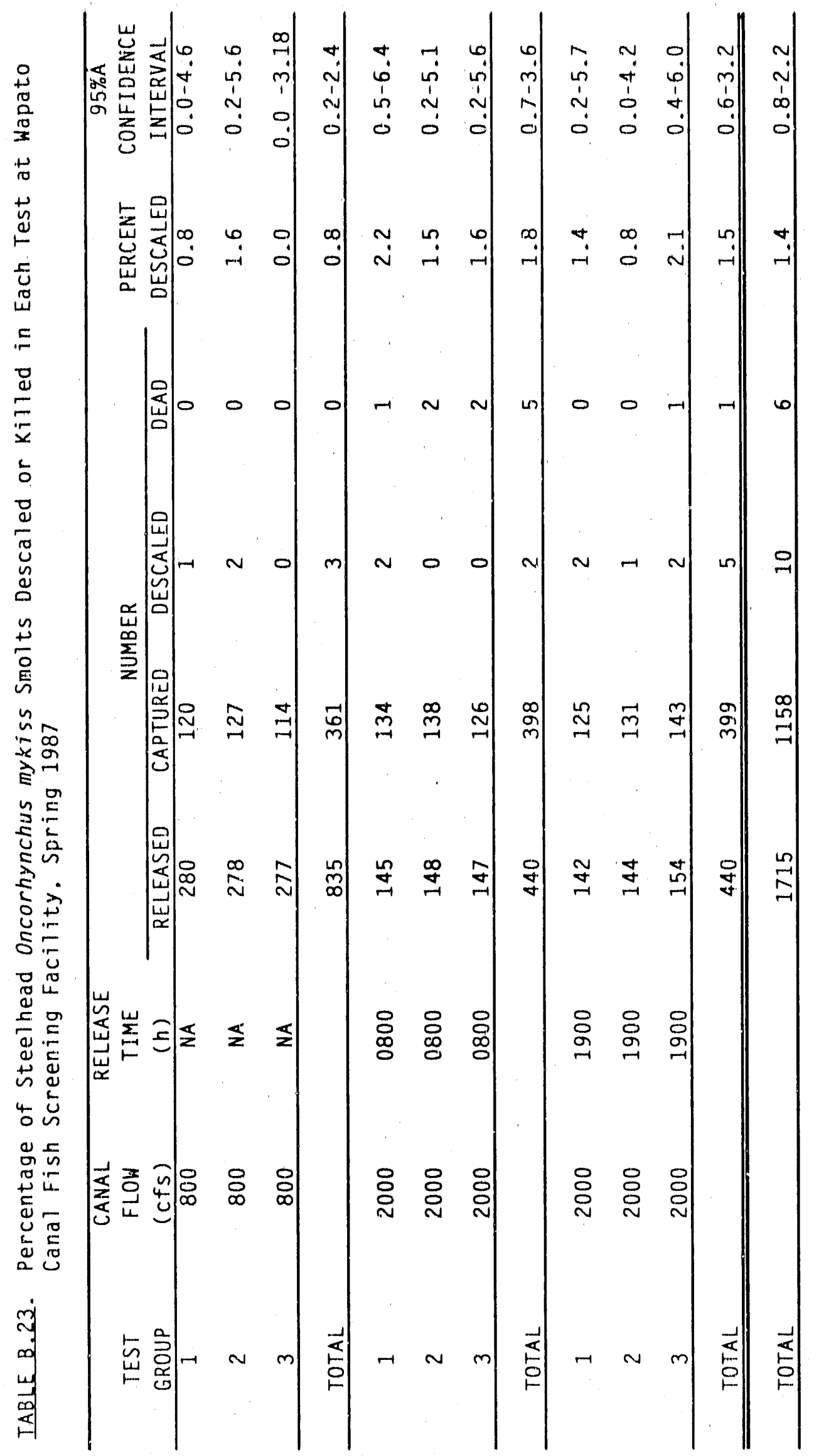




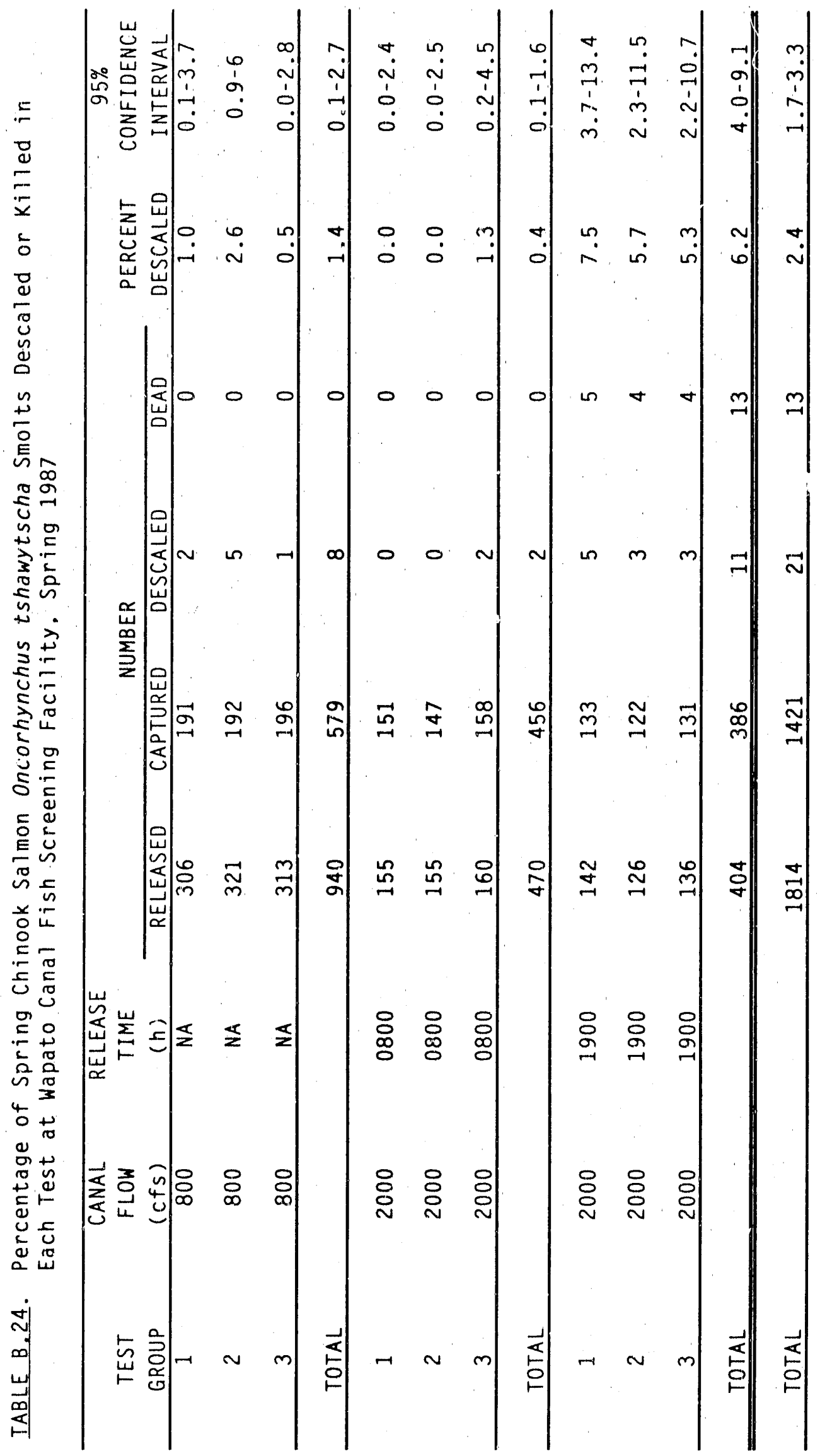

B. 17 
IABLE B.25. Scale Loss for Hatchery-Released and Native Salmonids Duririg Tests at Richland Canal Fish Screening Facility. Spring 1987

\begin{tabular}{|c|c|c|c|c|}
\hline \multirow[b]{2}{*}{ SPECIES } & \multicolumn{2}{|c|}{ NUMBER } & \multirow{2}{*}{$\begin{array}{l}\text { PERCENT } \\
\text { DESCALED }\end{array}$} & \multirow{2}{*}{$\begin{array}{l}95 \% \\
\text { CONFIDENCE } \\
\text { INTERVAL }\end{array}$} \\
\hline & CAUGHT & DESCALED & & \\
\hline Steelhead & 11 & 0 & 0.0 & 0.28 .5 \\
\hline Spring Chinook & 28 & 0 & 0.0 & $0-12.3$ \\
\hline Fall Chinook & 44 & $\ldots(a)$ & $\ldots(a)$ & $\ldots(a)$ \\
\hline (a) Not evalua & for desc & & & \\
\hline
\end{tabular}




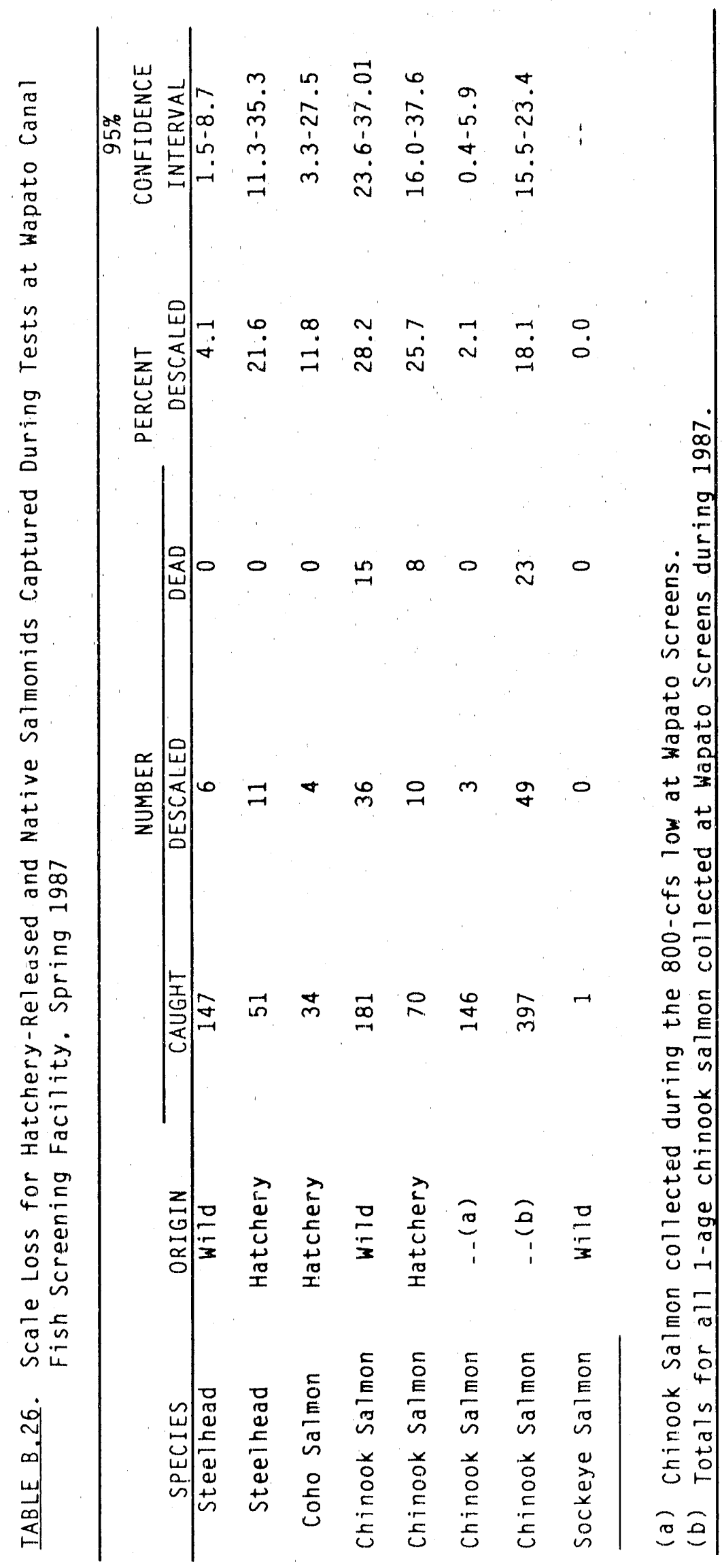

B. 19 
IABLE B.27. Percentage of Test Fish Descaled or Killed During Pipe Tests at Wapato Canal Fish Screening Facility, Spring 1987

\begin{tabular}{cccccc}
\hline & & NUMBER & & 95\% \\
SPECIES & RELEASED & CAPTURED & DESCALED & $\begin{array}{c}\text { PERCENT } \\
\text { DESCALED }\end{array}$ & $\begin{array}{c}\text { CONFIDENCE } \\
\text { INTERVAL }\end{array}$ \\
\cline { 2 - 6 } Spring Chinook & 150 & 135 & 8 & 5.9 & $2.6-11.3$ \\
Steelhead & 100 & 65 & 1 & 1.5 & $0.0-5.5$ \\
\hline
\end{tabular}




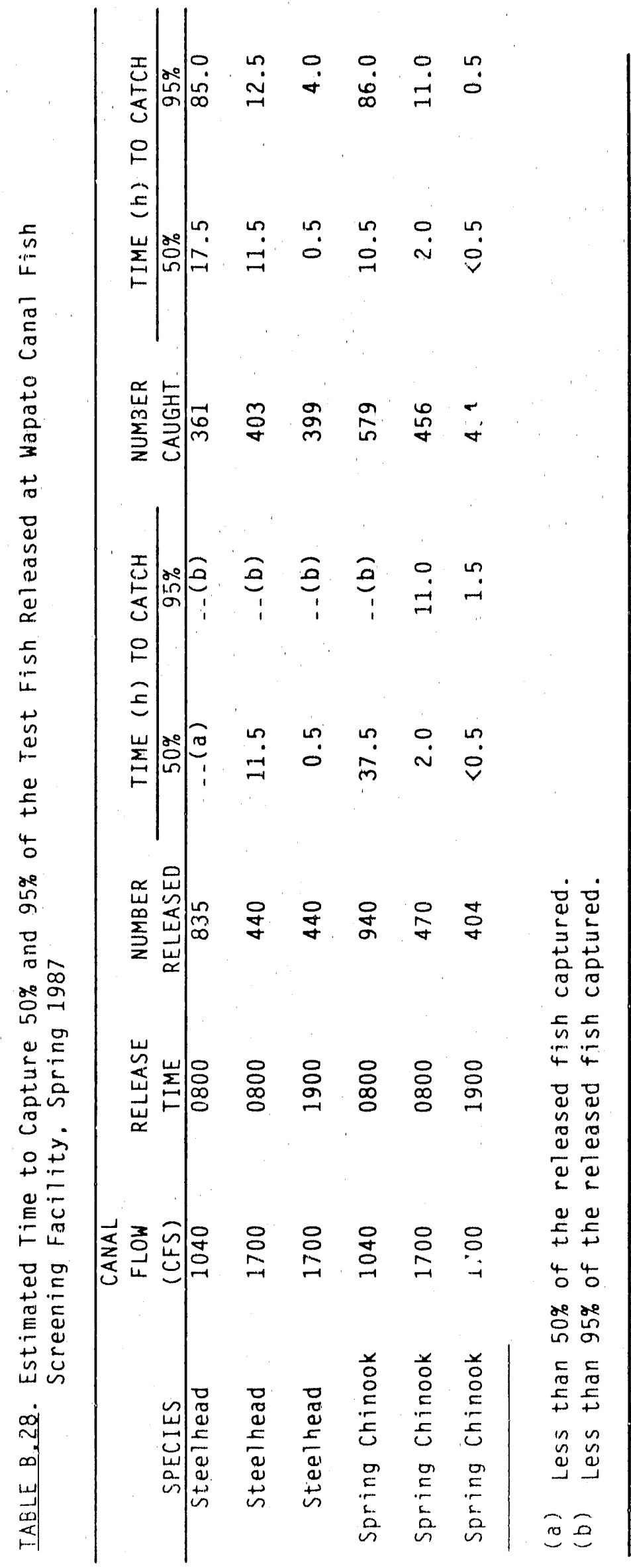

B. 21 


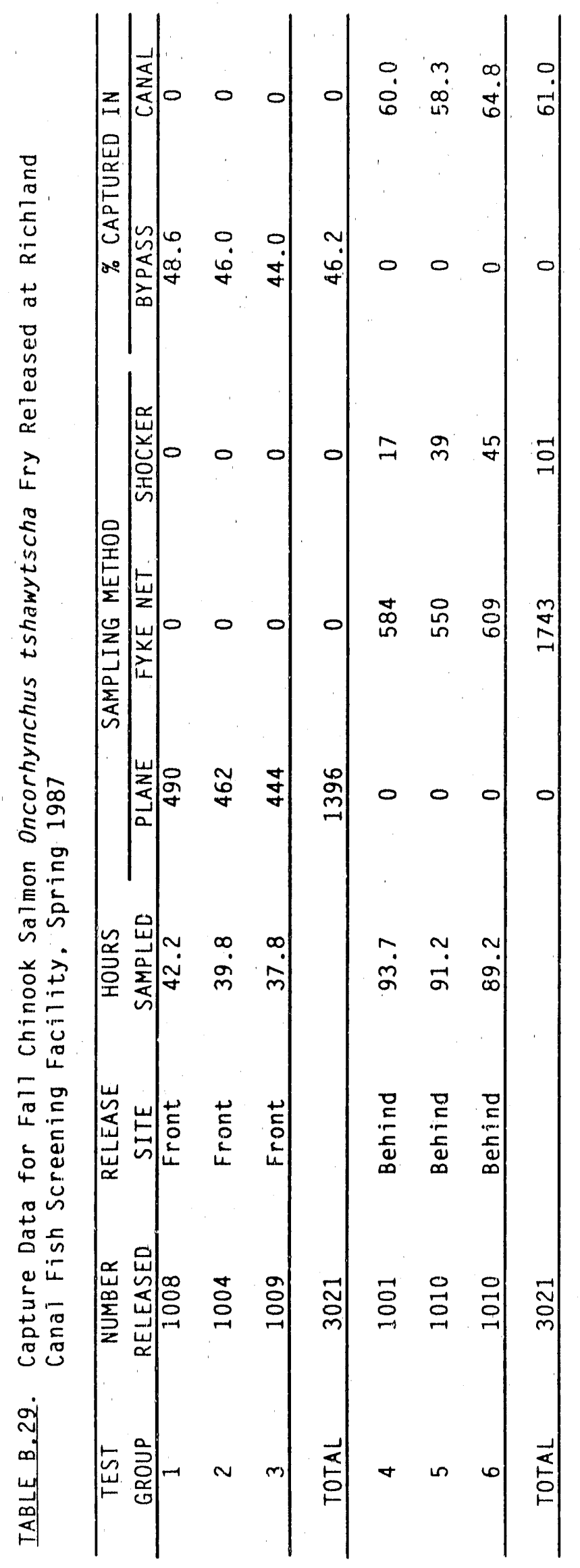


IABLE B.30. Capture Efflclencles of the Inclined Plane and Nets and Retention Efflciency of the Fyke Nets Used in Screen Integrity Tests at Wapato Canal Fish Screening Facllity. Spring 1987

\begin{tabular}{|c|c|c|c|c|c|c|}
\hline $\begin{array}{c}\text { SCREEN (a) } \\
\text { SECTION }\end{array}$ & \multicolumn{3}{|c|}{ CAPTURE PROBABILITY ESTIMATE } & E FOR & \multirow{2}{*}{$\begin{array}{c}\text { SCREEN } \\
\text { EFFICIENCY } \\
0.972\end{array}$} & \multirow{2}{*}{$\begin{array}{c}95 \% \\
\text { CONFIDENCE } \\
\text { INTERVAL }\end{array}$} \\
\hline$\frac{\text { SECTION }}{1-5}$ & $\frac{\text { INCLINED PLANE }}{0.94}$ & $\frac{\text { NET CAPTURE }}{0.33}$ & NET & $\frac{\text { RETENTION }}{0.55}$ & & \\
\hline $6-10$ & 0.98 & 0.45 & & 0.72 & 0.996 & $0.99-1.00$ \\
\hline $11-15$ & 0.95 & 0.93 & & 0.97 & 0.950 & $0.94-0.96$ \\
\hline $1-15$ & 0.95 & 0.57 & & 0.78 & 0.962 & $0.96-0.97$ \\
\hline $\begin{array}{l}\text { The } \\
\text { down }\end{array}$ & $\begin{array}{l}\text { is are numbe } \\
\text { n screen nea }\end{array}$ & $\begin{array}{l}\text { from the } \\
\text { the sepal }\end{array}$ & $\begin{array}{l}\text { tre } \\
\text { ion }\end{array}$ & $\begin{array}{l}\text { an screen } \\
\text { chamber. }\end{array}$ & $\begin{array}{l}\text { UMBER 1) } \\
\text { MBER 15). }\end{array}$ & the \\
\hline
\end{tabular}




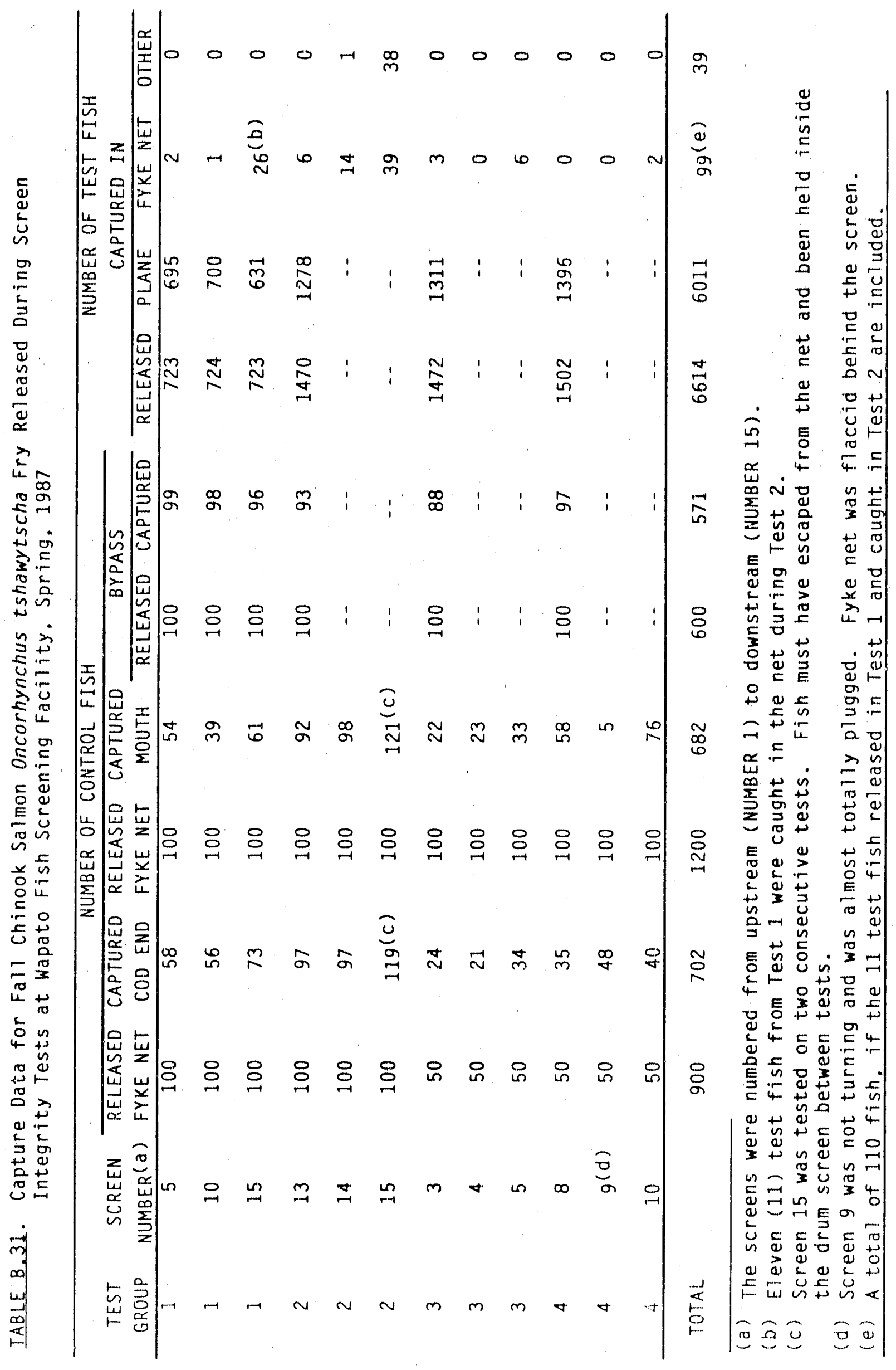




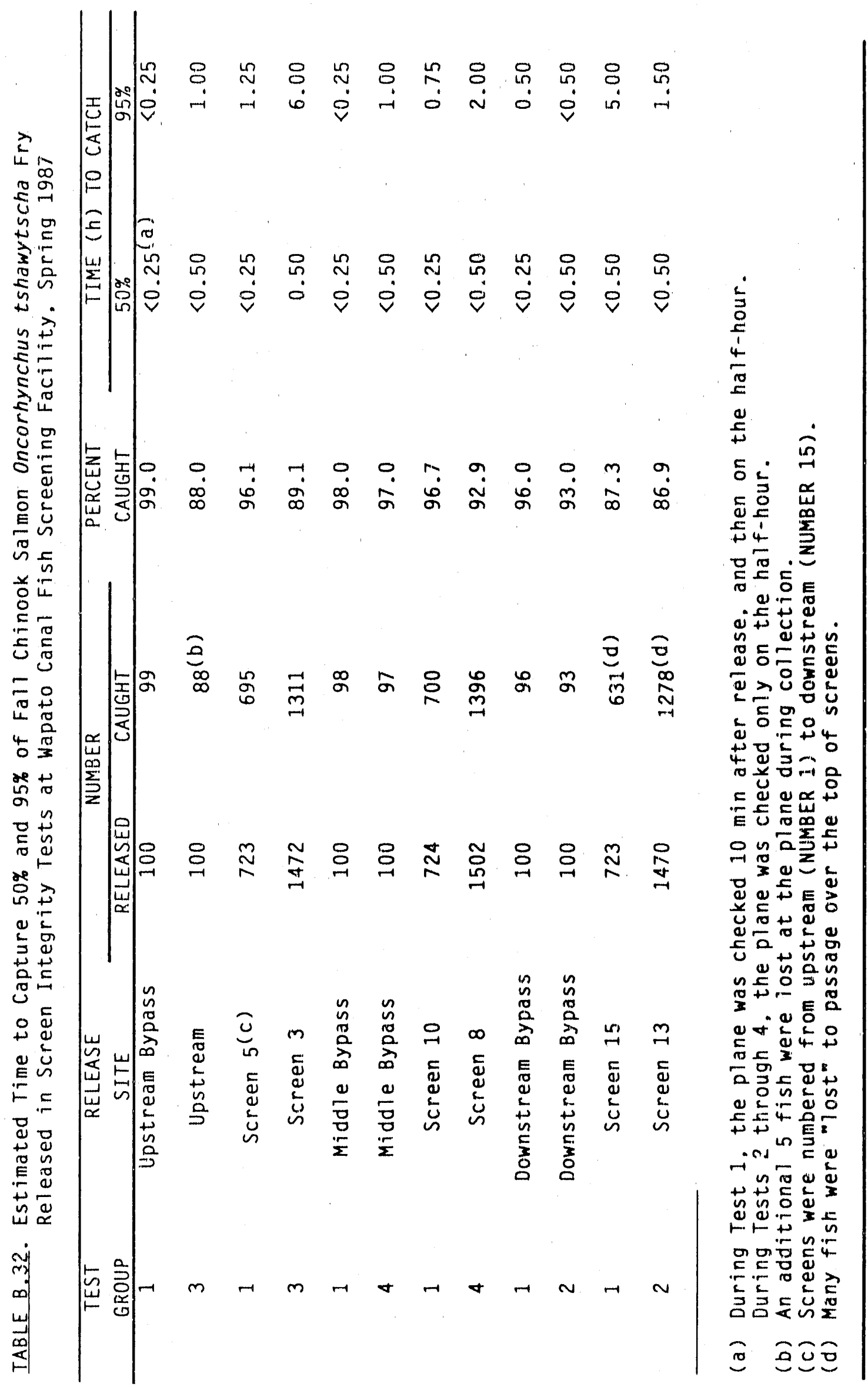


IABLE B.33. Percentage of Steelhead Oncorhynchus mykiss Smolts Descaled or kllled in Tests of the Inclined Plane at the Toppenish Creek Canal Fish Screening Factlity. Spring 1988

\begin{tabular}{|c|c|c|c|c|c|}
\hline \multirow{2}{*}{$\begin{array}{c}\text { TEST } \\
\text { REPLICATE }\end{array}$} & \multicolumn{3}{|c|}{ NUMBER OF FISH } & \multirow{2}{*}{$\begin{array}{l}\text { PERCENT } \\
\text { DESCALED }\end{array}$} & \multirow{2}{*}{$\begin{array}{c}95 \% \\
\text { CONFIDENCE } \\
\text { INTERVAL }\end{array}$} \\
\hline & RELEASED & CAPTURED & DESCALED & & \\
\hline 1 & 10 & 10 & 0 & 0.00 & $0-31$ \\
\hline 2 & 10 & 10 & 0 & 0.00 & $0-31$ \\
\hline 3 & 10 & 10 & 0 & 0.00 & $0-31$ \\
\hline 4 & 10 & 10 & 0 & 0.00 & $0-31$ \\
\hline 5 & 10 & 10 & 0 & 0.00 & $0-31$ \\
\hline 6 & 10 & 10 & 0 & 0.00 & 0.31 \\
\hline 7 & 10 & 9 & 0 & 0.00 & 0.34 \\
\hline 8 & 10 & 10 & 0 & 0.00 & $0-31$ \\
\hline 9 & 10 & 10 & 0 & 0.00 & $0-31$ \\
\hline 10 & 10 & 10 & 0 & 0.00 & 0.31 \\
\hline TOTAL & 100 & 99 & 0 & 0.00 & $0-4$ \\
\hline
\end{tabular}

IABLE B.34. Percentage of Steelhead Oncorhynchus mykiss Smolts Descaled Before Being Used in Tests at the Toppenish Creek Canal Fish Screening Facility, Spring 1988

\begin{tabular}{|c|c|c|c|c|}
\hline TEST & NUMBE & FISH & PERCENT & $\begin{array}{c}95 \% \\
\text { CONFIDENCE }\end{array}$ \\
\hline$\frac{\text { REPLICATE }}{1}$ & $\frac{\text { EXAMINED }}{70}$ & $\frac{\text { DESCALED }}{0}$ & $\frac{\text { DESCALED }}{0.00}$ & INTERVAL \\
\hline 2 & 70 & 0 & 0.00 & 0.5 \\
\hline 3 & 70 & 0 & 0.00 & 0.5 \\
\hline TOTAL & 210 & 0 & 0.00 & $0-2$ \\
\hline
\end{tabular}


IABLEB.35. Descaling and Mortality Data from Release and Capture Tests with Steelhead Oncorhynchus mykiss Smolts at the Toppentsh Creek Fish Screening Factlity. Spring 1988

\begin{tabular}{|c|c|c|c|c|c|c|c|}
\hline \multirow{2}{*}{$\begin{array}{l}\text { CANAL } \\
\text { FLOW } \\
\text { (CfS) }\end{array}$} & \multicolumn{4}{|c|}{ NUMBER } & \multicolumn{2}{|c|}{ PERCENT } & \multirow{2}{*}{$\begin{array}{c}95 \% \\
\text { CONFIUENCE } \\
\text { INTERVAL }\end{array}$} \\
\hline & RELEASED & CAPTURED & DESCALED & DEAD & CAPTURED & DESCALED & \\
\hline $\begin{array}{l}20 \\
50 \\
50\end{array}$ & $\begin{array}{l}250 \\
255 \\
250 \\
\end{array}$ & $\begin{array}{l}144 \\
199 \\
196 \\
\end{array}$ & $\begin{array}{l}0 \\
1 \\
0\end{array}$ & $\begin{array}{l}0 \\
0 \\
0\end{array}$ & $\begin{array}{l}57.6 \\
78.0 \\
78.4\end{array}$ & $\begin{array}{l}0.00 \\
0.50 \\
0.00\end{array}$ & $\begin{array}{l}0-2 \\
0-3 \\
0-2\end{array}$ \\
\hline Total & 755 & 539 & 1 & 0 & 71.4 & 0.19 & 0.1 \\
\hline$W+1 d$ & & 462 & 1 & 0 &. & 0.22 & 0.1 \\
\hline
\end{tabular}

IABLEB.36. Estimated Time to Capture 50\% of Steelhead Oncorhynchus mykiss Smolts Released in Descaling Tests at Toppenish Creek Fish Screening Factlity. Spring 1988

\begin{tabular}{|c|c|c|c|c|}
\hline \multirow{2}{*}{$\begin{array}{l}\text { CANAL } \\
\text { FLOW }\end{array}$} & \multicolumn{2}{|c|}{ NUMBER } & \multirow{2}{*}{$\begin{array}{l}\text { PERCENT } \\
\text { CAUGHT } \\
\end{array}$} & \multirow{2}{*}{$\begin{array}{c}\text { TIME (h) TO CATCH } \\
50 \%\end{array}$} \\
\hline & RELEAS: T & CAUGHT & & \\
\hline $20 \mathrm{cfs}$ & 250 & 144 & $57.6^{(a)}$ & 39.0 \\
\hline $\begin{array}{l}50 \mathrm{cfs} \\
50 \mathrm{cfs}\end{array}$ & $\begin{array}{l}255 \\
250\end{array}$ & $\begin{array}{l}199 \\
196\end{array}$ & $\begin{array}{l}78.0 \\
78.4\end{array}$ & $\begin{array}{l}16.0 \\
14.0\end{array}$ \\
\hline
\end{tabular}

(a) Inclined plane was removed for 2 h when canal flow was changed from 20 cfs to 50 cfs. Some fish from Test Group 1 may have moved out of the screen forebay during this period. Which may have contributed to the lower percent caught for Test Group 1.

IABLE B.37. Estimated Time to Capture $50 \%$ of Rainbow Trout Oncorhynchus mykiss Fry Released in Screen Integrity Te'sts at Toppenish Creek Fish Screening Facility. Spring 1988

\begin{tabular}{|c|c|c|c|c|}
\hline $\begin{array}{l}\text { TEST } \\
\text { GROUP } \\
\end{array}$ & RELEASED & BER & $\begin{array}{l}\text { PERCENT } \\
\text { CAUGHT }\end{array}$ & $\begin{array}{l}\text { TIME (h) TO CATCH } \\
50 \%\end{array}$ \\
\hline $\begin{array}{l}1 \\
2 \\
3\end{array}$ & $\begin{array}{l}1024 \\
1024 \\
1025\end{array}$ & $\begin{array}{l}868 \\
724 \\
781\end{array}$ & $\begin{array}{l}84.8 \\
70.7 \\
76.2\end{array}$ & $\begin{array}{l}4.0 \\
9.0 \\
4.0\end{array}$ \\
\hline
\end{tabular}


IABLE B.38. Percentage of Steelhead Oncorhynchus myktss Smolts Descaled in Pipe Tests at the Toppentsh Creek Fish Screening Factlity. Spring 1988

\begin{tabular}{|c|c|c|c|c|c|}
\hline $\begin{array}{l}\text { TEST } \\
\text { GROUP }\end{array}$ & \multicolumn{3}{|c|}{ NUMBER OF FISH } & $\begin{array}{l}\text { PERCENT } \\
\text { DESCALED }\end{array}$ & $\begin{array}{c}95 \% \\
\text { CONFIDENCE } \\
\text { INTERVAL }\end{array}$ \\
\hline $\begin{array}{c}1 \\
2 \\
3 \\
4 \\
5 \\
6 \\
7 \\
8 \\
9 \\
10 \\
11 \\
12 \\
13\end{array}$ & $\begin{array}{l}10 \\
10 \\
10 \\
10 \\
10 \\
10 \\
10 \\
10 \\
10 \\
10 \\
10 \\
10 \\
10\end{array}$ & $\begin{array}{l}\text { (a) } \\
\text { (a) } \\
\text { (a) } \\
\text { (a) } \\
\text { (a) } \\
\text { (a) } \\
\text { (a) } \\
\text { (a) } \\
\text { (a) } \\
\text { (a) } \\
\text { (a) } \\
\text { (a) } \\
\text { (a) }\end{array}$ & $\begin{array}{l}0 \\
0 \\
0 \\
0 \\
0 \\
0 \\
0 \\
0 \\
0 \\
0 \\
0 \\
0 \\
0\end{array}$ & $\begin{array}{l}: \\
: \\
: \\
: \\
:\end{array}$ & $\begin{array}{l}: \\
\vdots \\
\vdots \\
\vdots\end{array}$ \\
\hline Total & 130 & 106 & 0 & 0.0 & 0.3 \\
\hline
\end{tabular}

(a) Groups of ten fish were released at the head of the fish return pipe every 3 to $6 \mathrm{~min}$. We were not able to determine capture or descaling rates for individual release groups, because sampling at the end of the pipe was continuous. 


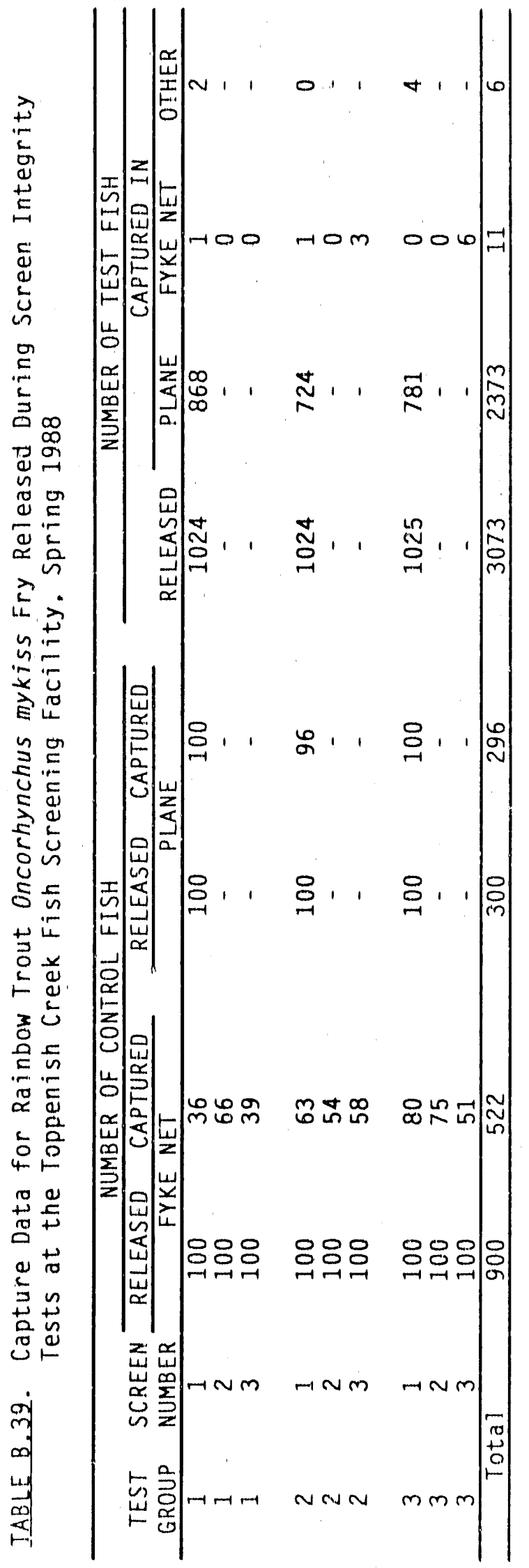


IABLE B.40. Capture Effictency of the Inclined Plane and Fyke Nets Used During Soreen Integrity Tests at the Toppentsh Creek Fish Screening Facility. Spring 1988

\begin{tabular}{|c|c|c|c|c|c|}
\hline \multicolumn{2}{|c|}{ SCREEN } & \multicolumn{2}{|c|}{$\begin{array}{l}\text { CAPTURE PROBABILITY ESTIMATE } \\
\text { INCLINED PLANE }\end{array}$} & $\begin{array}{l}\text { SCREEN } \\
\text { EFFICIENCY } \\
\end{array}$ & $\begin{array}{c}95 \% \\
\text { CONFIDENCE } \\
\text { INTERVAL. }\end{array}$ \\
\hline & $\begin{array}{l}1 \\
2 \\
3 \\
a\end{array}$ & $\begin{array}{l}0.987 \\
0.987 \\
0.987 \\
0.966\end{array}$ & $\begin{array}{l}0.597 \\
0.650 \\
0.493 \\
0.580\end{array}$ & $\begin{array}{l}0.999 \\
1.000 \\
0.992 \\
0.966\end{array}$ & $\begin{array}{l}1.00-1.00 \\
1.00-1.00 \\
1.00-1.00 \\
0.95-0.98\end{array}$ \\
\hline A 11 & Screens & 0.987 & 0.580 & 0.991 & $0.99-1.00$ \\
\hline (a) & \multicolumn{5}{|c|}{$\begin{array}{l}\text { During the tests, } 37 \text { control fish placed in the fyke nets were caught } \\
\text { on the triclined plane. Assuming the } 37 \text { fish were test fish that } \\
\text { passed from the forebay to the area behind the screens, we calculated } \\
\text { a "worst case" screen effictency of } 0.97( \pm 0.015) \text {. }\end{array}$} \\
\hline
\end{tabular}

IABLE B.41. Estimated Time to Capture $50 \%$ of Fall Chinook Salmon Oncorhynchus tshawytscha Fry Released in Screen Integrity Tests at the Wapato Fish Screening Facility, Spring 1988

\begin{tabular}{cccccc}
\hline TEST & & \multicolumn{2}{c}{ NUMBER } & PERCENT & TIME $(h)$ TO CATCH \\
\cline { 3 - 4 } GROUP & SCREENS & REL.EASED & CAUGHT & CAUGHT & $50 \%$ \\
\hline & 5 & 1044 & 775 & 74.2 & 6.5 \\
1 & 10 & 1041 & 816 & 78.4 & 7.0 \\
1 & 15 & 1042 & 535 & 51.3 & 7.5 \\
1 & $13-15$ & 1041 & 620 & 59.6 & 4.5 \\
2 & $3-5$ & 1028 & 675 & 65.7 & 0.5 \\
3 & 15 & 1039 & 959 & 92.3 & 1.0 \\
\hline
\end{tabular}




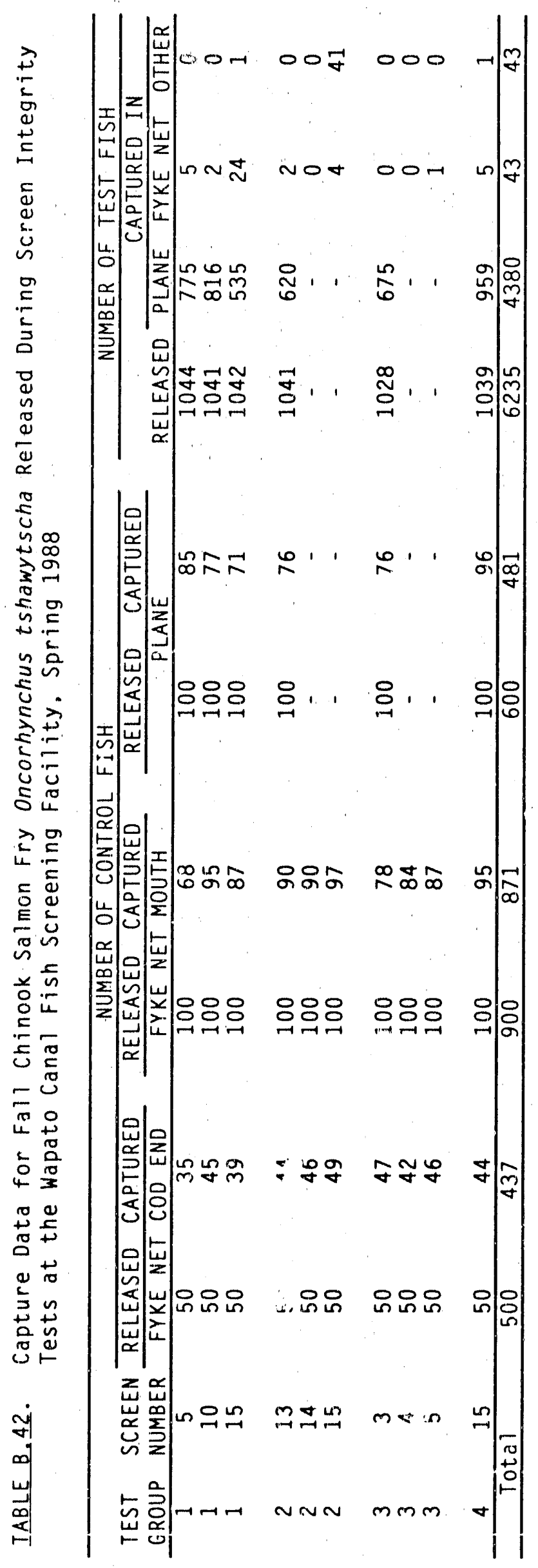

B. 31 
IABLE B.43. Capture Efficiency of the Inclined Plane and Nets and Retention Efficiency for Fyke Nets Used During Screen Integrity Tests at the Wapato Canal Fish Screening Facility. spring 1988

\begin{tabular}{|c|c|c|c|c|c|}
\hline \multirow[b]{2}{*}{$\begin{array}{l}\text { SCREEN } \\
\text { SECTION (A) }\end{array}$} & \multicolumn{3}{|c|}{ PROBAB ILITY ESTIMATE } & \multirow[b]{2}{*}{$\begin{array}{l}\text { SCREEN } \\
\text { EFFICIENCY }\end{array}$} & \multirow{2}{*}{$\begin{array}{c}95 \% \\
\text { CONFIDENCE } \\
\text { INTERVAL }\end{array}$} \\
\hline & $\begin{array}{l}\text { PLANE } \\
\text { CAPTURE }\end{array}$ & $\begin{array}{l}\text { NET } \\
\text { CAPTURE }\end{array}$ & $\begin{array}{l}\text { NET } \\
\text { RETENTION }\end{array}$ & & \\
\hline $\begin{array}{c}1-5 \\
6-10 \\
11-15 \\
15 \\
1-15\end{array}$ & $\begin{array}{l}0.805 \\
0.770 \\
0.810 \\
0.960 \\
0.802\end{array}$ & $\begin{array}{l}0.793 \\
0.950 \\
0.918 \\
0.950 \\
0.968\end{array}$ & $\begin{array}{l}0.850 \\
0.900 \\
0.888 \\
0.880 \\
0.874\end{array}$ & $\begin{array}{l}0.995 \\
0.998 \\
0.984 \\
0.994 \\
0.991\end{array}$ & $\begin{array}{l}0.99-1.00 \\
0.99-1.00 \\
0.98-0.99 \\
0.99-1.00 \\
0.99-1.00\end{array}$ \\
\hline
\end{tabular}

(a) The screens are numbered from the upstream screen (NUMBER 1 ) to the downstream screen nearest the separation chamber. (NUMEER 15).

IABLE B.44. Capture Data from Fyke Nets Behind Selected Screens at the Wapato Canal Fish Screening Facility After the Release of Yakima Indian Nation (YIN) Fall Chinook Salmon Oncorhynchus tshawytscha from Net Pens in the Wapato Screen Forebay. Spring 1988

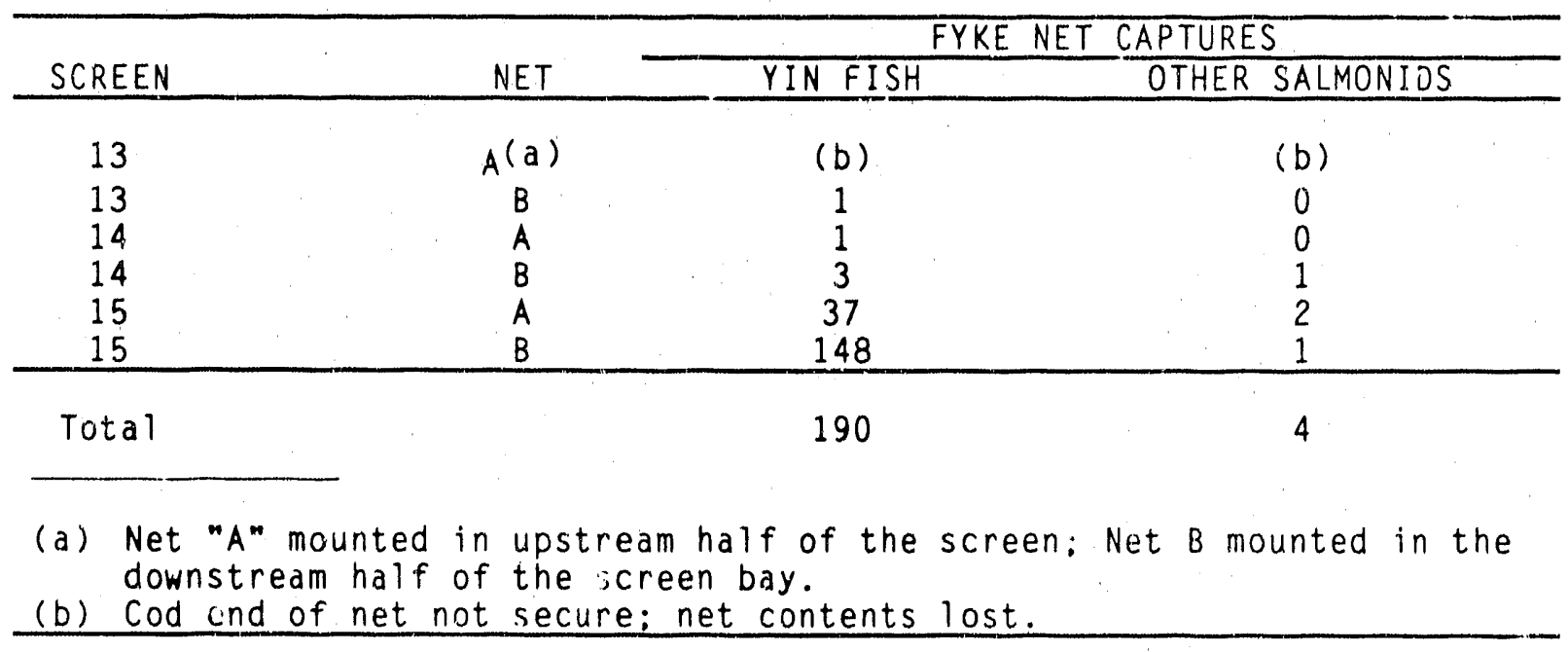


TABLE B.45. Estimated Time to Capture $50 \%$ of Fall Chinook Oncorhynchus tshawytscha Fry Released in Screen Integrity Tests at the Sunnyside Fish screening Facility, Spring 1988

\begin{tabular}{ccccc}
\hline TEST & \multicolumn{2}{c}{ NUMBER } & PERCENT & TIME $(h)$ TO CATCH \\
\cline { 2 - 5 } GROUP & RELEASED & CAUGHT & CAUGHT & $50 \%$ \\
\hline & & & & \\
1 & 1045 & 746 & 71.4 & 1.0 \\
2 & 1047 & 791 & 75.5 & 1.0 \\
3 & 1047 & 891 & 85.1 & $<0.5$ \\
4 & 1047 & 845 & 80.7 & $<0.5$ \\
\hline
\end{tabular}




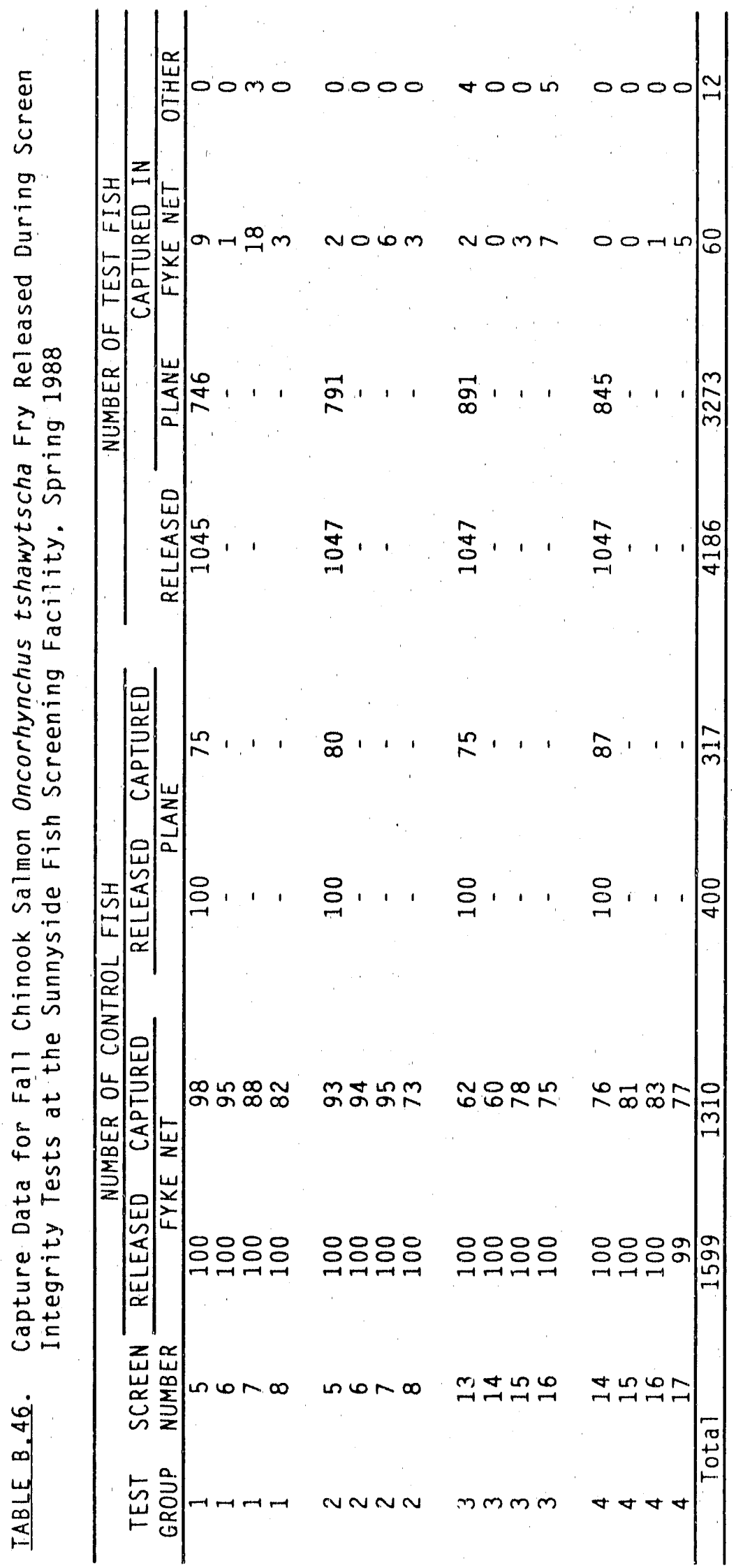


TABLE B.47. Capture Efficiency of the Inclined Plane and Fyke Nets Used During Screen Integrity Tests at the Sunnyside Canal Fish Screening Facility, Spring 1988

\begin{tabular}{|c|c|c|c|c|}
\hline \multirow[b]{2}{*}{$\begin{array}{l}\text { SCREEN } \\
\text { SECTION (a) }\end{array}$} & \multicolumn{3}{|c|}{ PROBAB I LITY ESTIMATE } & \multirow{2}{*}{$\begin{array}{c}95 \% \\
\text { CONFIDENCE } \\
\text { INTERVAL }\end{array}$} \\
\hline & $\begin{array}{l}\text { PLANE } \\
\text { CAPTURE }\end{array}$ & $\begin{array}{c}\text { NET } \\
\text { CAPTURE }\end{array}$ & $\begin{array}{l}\text { SCREEN } \\
\text { EFFICIENCY }\end{array}$ & \\
\hline $\begin{array}{l}3-8(\text { test } 1) \\
3-8(\text { test } 2) \\
3-8\end{array}$ & $\begin{array}{l}0.750 \\
0.800 \\
0.775\end{array}$ & $\begin{array}{l}0.908 \\
0.888 \\
0.898\end{array}$ & $\begin{array}{l}0.967 \\
0.988 \\
0.977\end{array}$ & $\begin{array}{l}0.96-0.98 \\
0.98-1.00 \\
0.97-0.98\end{array}$ \\
\hline $\begin{array}{l}9-17 \text { (test } 3) \\
9-17 \text { (test } 4) \\
9-17\end{array}$ & $\begin{array}{l}0.750 \\
0.870 \\
0.810 \\
\end{array}$ & $\begin{array}{l}0.688 \\
0.794 \\
0.741 \\
\end{array}$ & $\begin{array}{l}0.986 \\
0.992 \\
0.989\end{array}$ & $\begin{array}{l}0.98-1.00 \\
0.99-1.00 \\
0.98-0.99 \\
\end{array}$ \\
\hline $3-17$ & 0.793 & 0.819 & 0.983 & 0.99 \\
\hline
\end{tabular}

(a) The screens are numbered from the upstream screen (NUMBER 1) to the downstream screen nearest the separation chamber (NUMBER 17). Screens 1 and 2 are permanently out of service.

IABLE B.48. Capture Data from Fyke Nets Behind Selected Screens at the Sunnyside Canal Fish Screening Facility After the Release of Yakima Indian Nation (YIN) Fall Chinook Salmon Oncorhynchus tshawytscha Fingerlings From the Wapato Screens Forebay. spring 1988

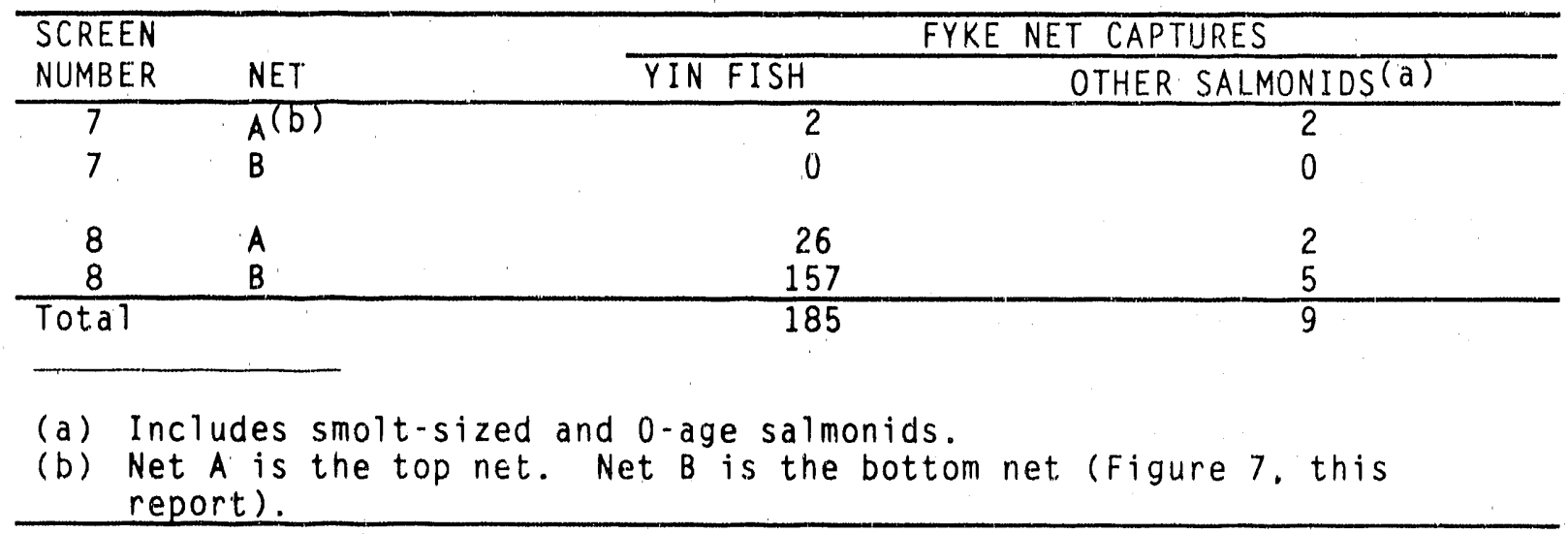




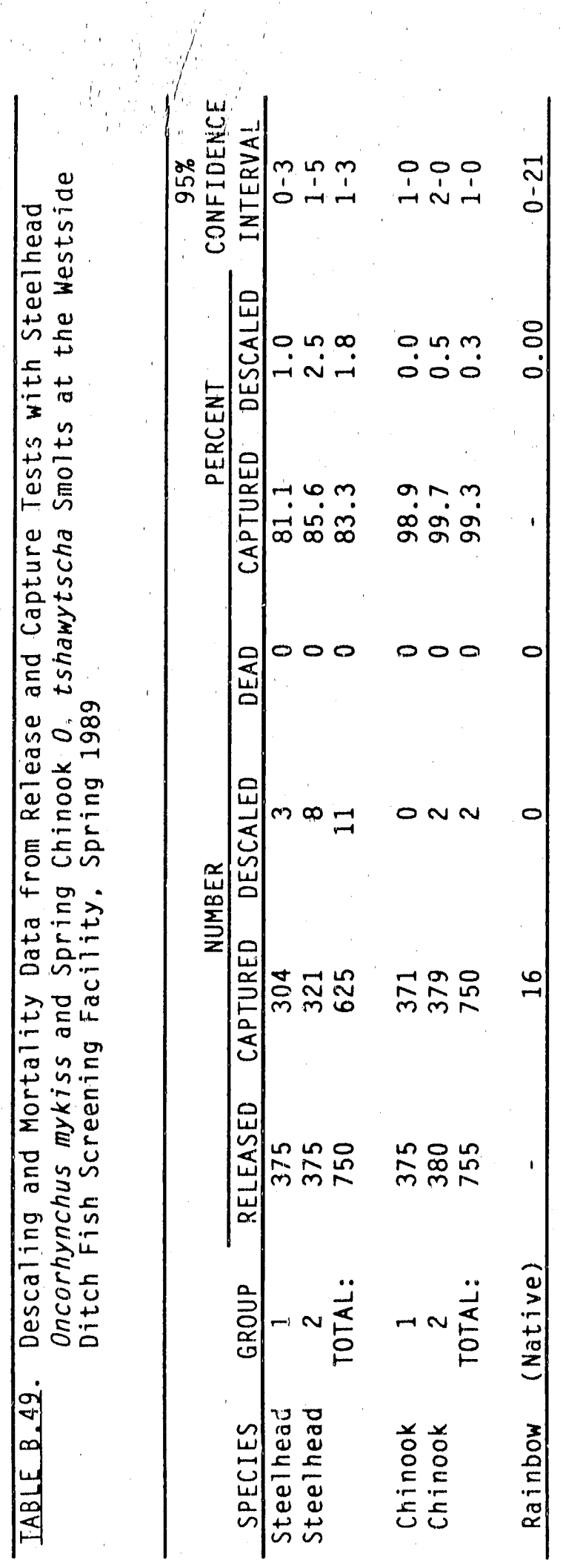

B. 36 


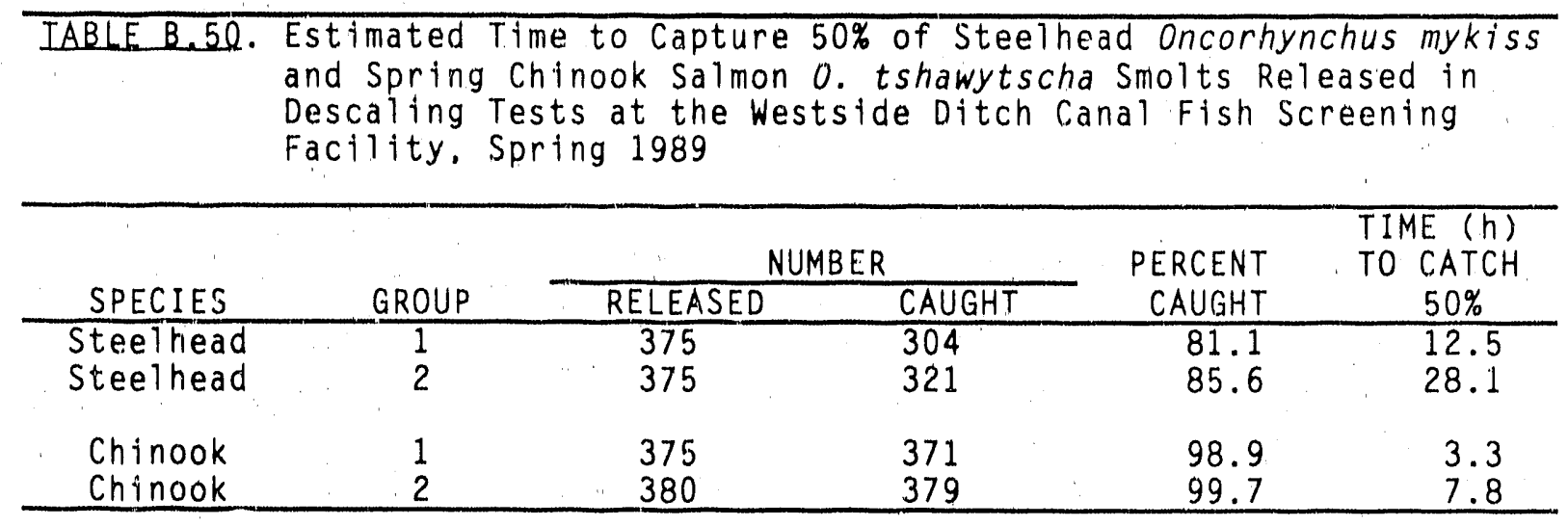

IABLE B.51. Percentage of Spring Chinook Salmon Oncorhynchus tshawytscha
Smolts Descaled in Pipe Tests at the Wapato Canal Fish
Screening Facility. Spring 1989




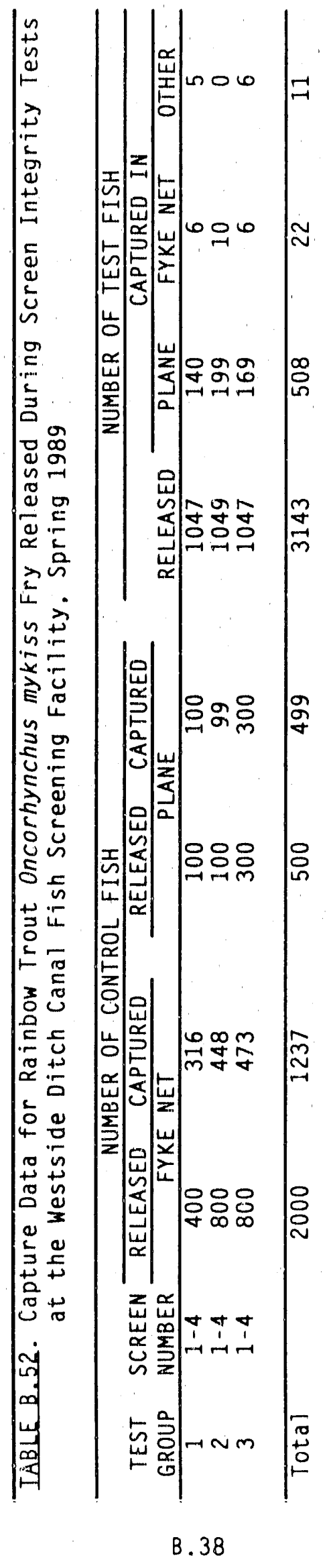




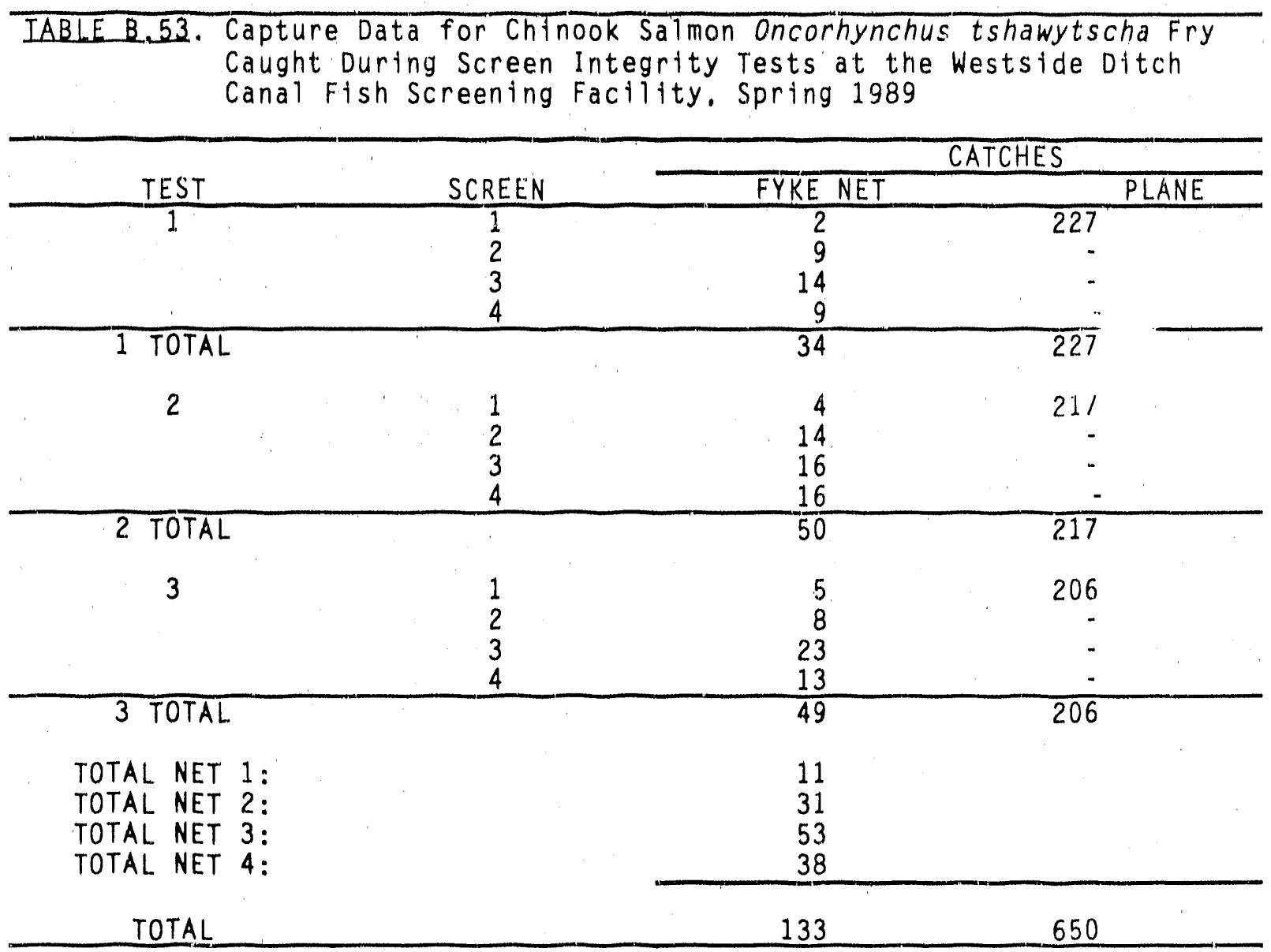

\begin{tabular}{ccccc}
\hline IABLE B.54. Capture Efficiency of the Inclined Plane and Fyke Nets Used \\
During Screen Integrity Tests at the Westside Ditch Canal Fish \\
Screening Facility. Spring 1989
\end{tabular}



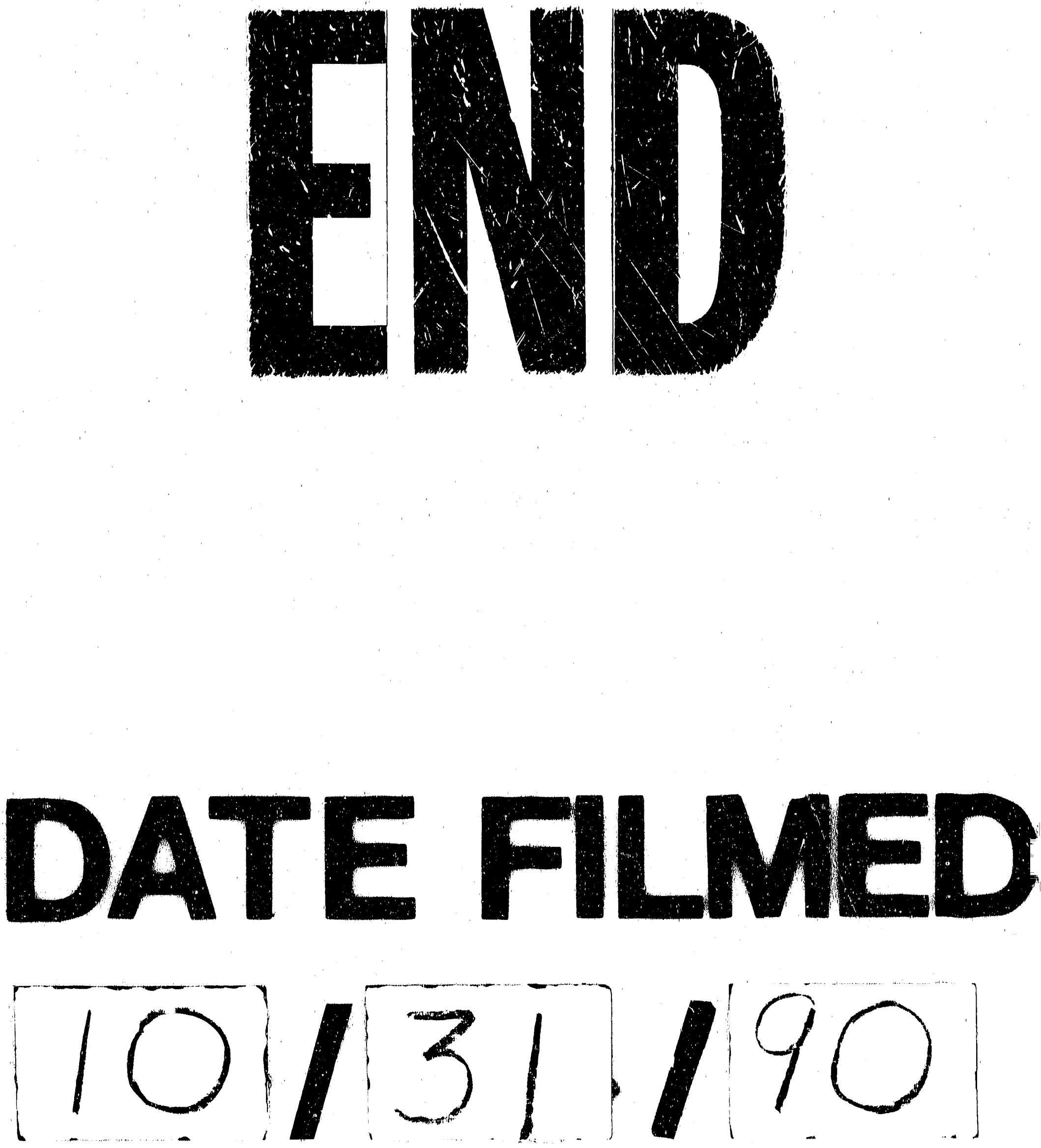
